\title{
DIMENSIONAMENTO E SIMULAÇÃO HIDRÁULICA DA IRRIGAÇÃO LOCALIZADA SOB CONDIÇÃO VARIÁVEL DE SETORES DE OPERAÇÃO
}

\author{
GUILHERME BUSI DE CARVALHO
}

Dissertação apresentada à Escola Superior de

Agricultura "Luiz de Queiroz", Universidade de São

Paulo, para obtenção do título de Mestre em Agronomia, Área de Concentração: Irrigação e Drenagem.

P I R A C I C A B A

Estado de São Paulo - Brasil

OUTUBRO - 2004 


\title{
DIMENSIONAMENTO E SIMULAÇÃO HIDRÁULICA DA IRRIGAÇÃO LOCALIZADA SOB CONDIÇÃO VARIÁVEL DE SETORES DE OPERAÇÃO
}

\section{GUILHERME BUSI DE CARVALHO}

Engenheiro Agrônomo

\author{
Orientador: Prof. Dr. RUBENS DUARTE COELHO
}

\begin{abstract}
Dissertação apresentada à Escola Superior de Agricultura "Luiz de Queiroz", Universidade de São Paulo, para obtenção do título de Mestre em Agronomia, Área de Concentração: Irrigação e Drenagem.
\end{abstract}

P I R A C I C A B A

Estado de São Paulo - Brasil

OUTUBRO - 2004 


\section{Dados Internacionais de Catalogação na Publicação (CIP) DIVISÃO DE BIBLIOTECA E DOCUMENTAÇÃO - ESALQ/USP}

\section{Carvalho, Guilherme Busi de}

Dimensionamento e simulação hidráulica da irrigação localizada sob condição variável de setores de operação / Guilherme Busi de Carvalho. - - Piracicaba, 2004. 78 p. : il.

Dissertação (mestrado) - - Escola Superior de Agricultura Luiz de Queiroz, 2004. Bibliografia.

1. Dimensionamento 2. Irrigação localizada - Otimização 3. Irrigação por microaspersão 4. Hidráulica - Simulação I. Título

CDD 631.7 
Aos meus pais,

\section{OFEREÇO.}

Para minha esposa Stella, e a nosso filho Raphael

DEDICO. 


\section{AGRADECIMENTOS}

A Deus pela vida e pelas graças alcançadas;

A minha esposa Stella, pela compreensão, dedicação, amor e companheirismo durante toda minha vida;

Ao meu filho Raphael, pelo amor, alegria e sinceridade;

Ao Prof. Dr. Rubens Duarte Coelho, por toda orientação e confiança durante o curso;

Aos meus pais Nelson e Vera e minha irmã Daniela, pelo apoio e ajuda durante o curso de pós-graduação;

Ao Departamento de Engenharia Rural da Escola Superior de Agricultura "Luiz de Queiroz" (ESALQ/USP) pela oportunidade de realizar o mestrado;

Ao CNPQ, Ministério de Ciência e Tecnologia, pela concessão da bolsa de estudos;

Aos Engenheiros Agrônomos Marco e Wulf e ao Geólogo Saad pela ajuda e amizade;

Aos funcionários do Departamento de Hidráulica, Gilmar, Hélio, César (in memoriam), Antônio, Oswaldo, Davilmar e Sandra.

Aos funcionário da biblioteca Central da ESALQ/USP, pelo auxílio na elaboração deste trabalho;

Enfim, a todos os meus amigos e professores do curso de Pós-Graduação e da empresa Irrigart Engenharia e Consultoria em Recursos Hídricos e Meio Ambiente. 


\section{SUMÁRIO}

Página

LISTA DE FIGURAS............................................................................ viii

LISTA DE TABELAS ................................................................... xi

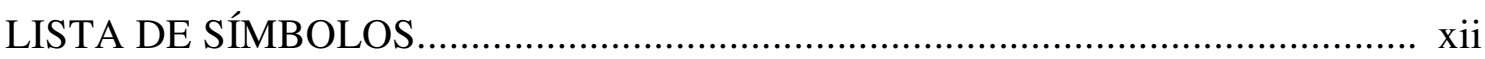

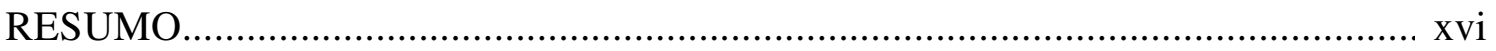

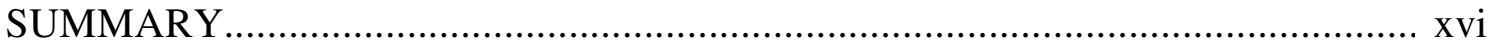

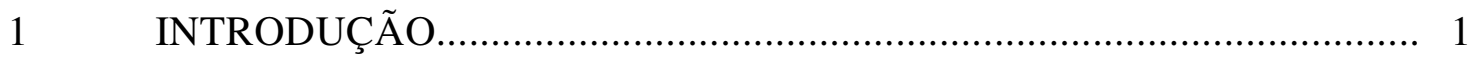

2 REVISÃO DE LITERATURA..................................................... 3

2.1 A irrigação no contexto dos recursos hídricos............................... 3

2.2 A irrigação localizada.................................................... 4

2.2.1 Crescimento da irrigação localizada................................. 4

2.2.2 Vantagens.................................................................... 5

2.2.3 Desvantagens............................................................ 7

2.2.4 Características dos componentes do sistema................................ 8

2.3 Hidráulica da irrigação localizada.......................................... 9

2.3.1 Concepção de projeto..................................................... 9

2.3.2 Hidráulica de tubulação principal....................................... 9

2.3.2. Fórmula de Darcy-Weisbach (Universal) $\quad$............................ 9

2.3.2. Fórmula de Hazen-Williams........................................ 13

2.4 Bombeamento........................................................ 14

2.4.1 Bombas hidráulicas..................................................... 14

2.4.2 Seleção de Bombas............................................................... 14

2.4.3 Cálculo da potência......................................................... 17

$2.5 \quad$ Seleção de motores......................................................... 18

2.5.1 Motores elétricos......................................................... 18 


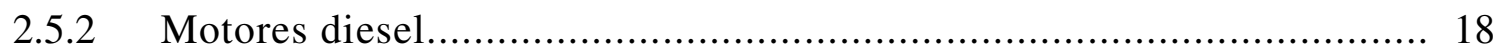

2.6 Otimização de projetos............................................................... 22

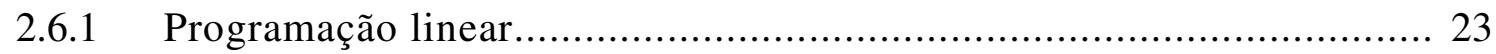

2.6.2 Programação não linear.............................................................. 24

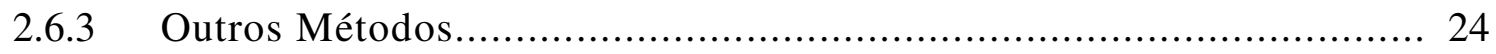

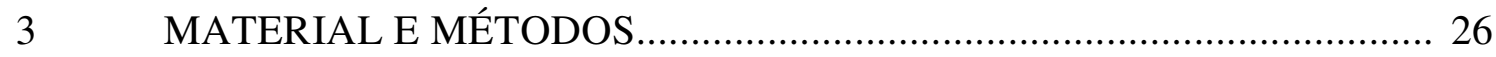

3.1 Considerações iniciais sobre o aplicativo PLANLOC $1.0 \ldots \ldots \ldots \ldots \ldots \ldots . . . . . .26$

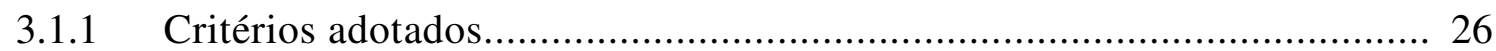

3.1.2 Classificação dos resultados.................................................. 27

3.2 Descrição do aplicativo PLANLOC 1.0............................................. 27

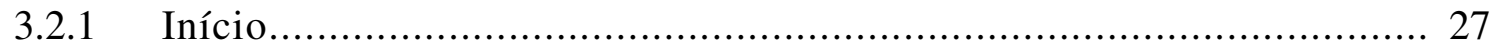

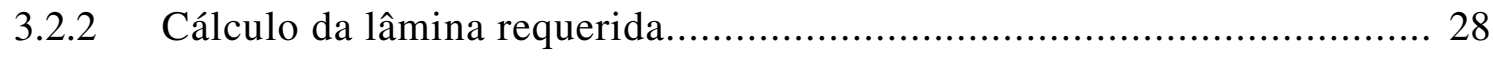

3.2.3 Definição do layout e setorização............................................. 29

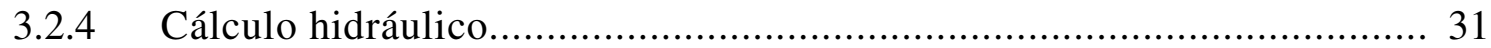

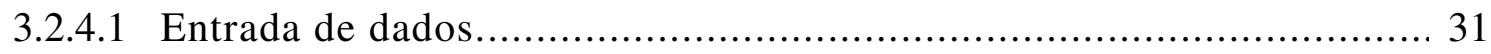

3.2.4.2 Cálculo hidráulico da vazão e pressão requerido pelo sistema....... 33

3.2.5 Seleção do conjunto moto-bomba........................................... 34

3.2.6 Simulação de funcionamento do projeto....................................... 36

3.2.6.1 Simulação do conjunto moto-bomba...................................................... 36

3.2.6.2 Cálculo hidráulico das pressões nos trechos............................. 36

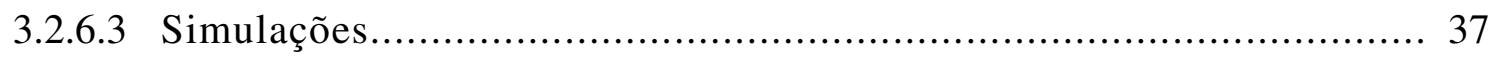

3.3 Caracterização da área para aplicação do modelo....................................... 39

3.3.1 Localização e área......................................................................... 39

3.3.2 Caracterização do pomar................................................................... 39

3.4 Caracterização do projeto de irrigação para aplicação do modelo......... 40

3.4.1 Projeto executivo..................................................................... 40

3.4.2 Dados técnicos do projeto de irrigação............................................ 40

3.4.3 Quadro de funcionamento....................................................... 41

$4 \quad$ RESULTADOS E DISCUSSÃO....................................................... 42

4.1 Caracterização do Aplicativo......................................................... 42 
4.1.1 Definição do número de setores de irrigação.......................................... 43

4.1.2 Definição do layout da irrigação......................................................... 45

4.1.3 Definição do traçado da tubulação............................................... 46

4.1.4 Dimensionamento da malha hidráulica.............................................. 47

4.1.5 Seleção do conjunto moto-bomba....................................................... 48

4.1.6 Ajuste da malha hidráulica ao conjunto moto-bomba...................................... 51

4.1.7 Simulação de operação.................................................................................. 52

4.2 Simulação do aplicativo PLANLOC 1.0............................................. 54

4.2.1 Descrição do layout do projeto.............................................. 54

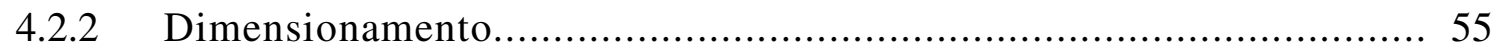

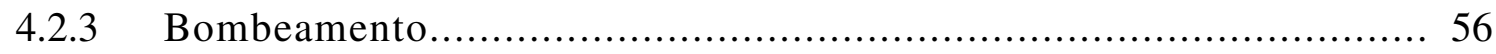

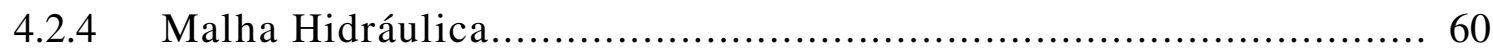

4.2.5 Simulação 1: Operação do sistema sem irrigar uma variedade........................ 62

4.2.6 Simulação 2: Operação do sistema sem irrigar duas variedades....................... 63

4.2.7 Simulação 3: Desligamento de 1 conjunto moto-bomba visando solucionar o problema de sobre-pressão da malha hidráulica na Simulação 2 ................. 64

4.2.8 Simulação 4: irrigação das variedades de laranja valência, hamlin, pêra rio

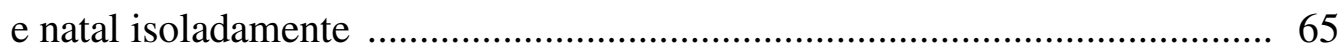

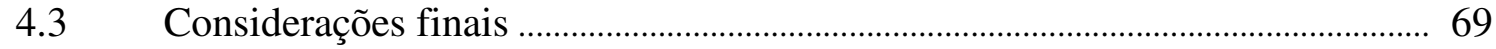

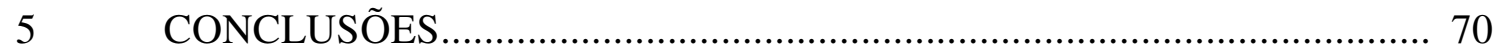

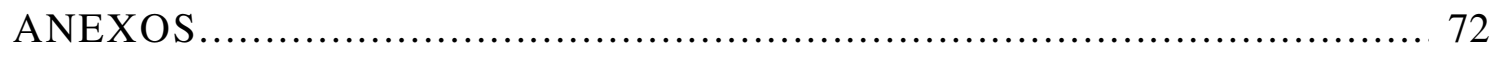

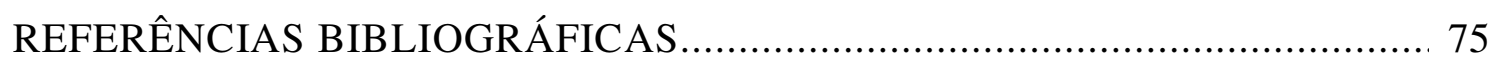




\section{LISTA DE FIGURAS}

Página

1 Curvas topográficas do motor MWM em gráfico tridimensional do mapa de desempenho

2 Mapa de desempenho de motor diesel e perfil das curvas do corte "AA" para rotação fixa e do corte "BB" para torque fixo 20

3 Curva de otimização operacional, traçada sobre o mapa de desempenho de motor diesel

4 Fluxograma geral do aplicativo PLANLOC 1.0 ……………………………....... 28

5 Fluxograma do cálculo da lâmina requerida ............................................................ 29

6 Fluxograma para definição do layout e setorização.................................................... 30

7 Células de entrada para montagem dos setores de irrigação........................................ 33

8 Fluxograma para determinação do ponto de trabalho da moto-bomba....................... 35

9 Fluxograma para simulação da malha hidráulica em função da alteração dos pontos de trabalho do conjunto moto-bomba.......................................................... 38

10 Visão esquemática da distribuição dos setores de funcionamento na área ................ 41

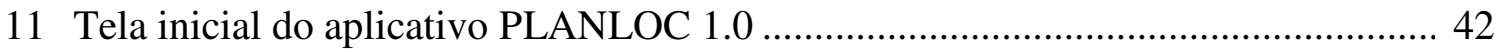

12 Planilha para dimensionamento do número de setores para microaspersão .............. 44

13 Planilha para dimensionamento do número de setores para gotejamento ................. 44

14 Tela da planilha "Dados" ....................................................................................... 47

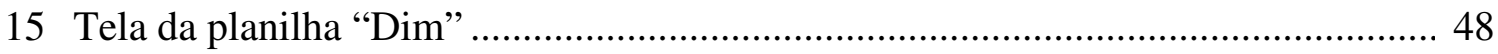

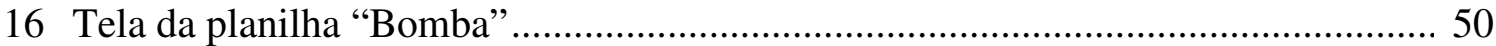

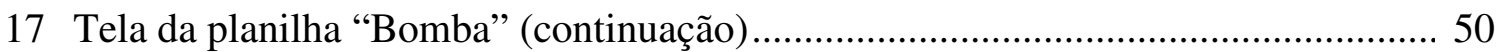


18 Entrada de dados da simulação do bombeamento na planilha "Dim" ..................... 52

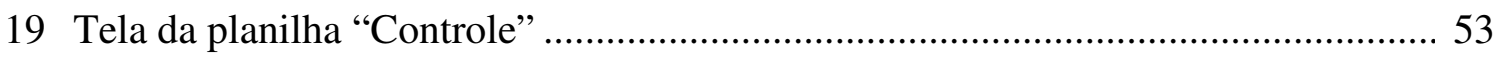

20 Pressões e vazões requeridas para cada trecho nos seis setores de irrigação............ 56

21 Ajuste das equações das curvas dos parâmetros do conjunto moto-bomba com diâmetro de rotor de 405 mm e 1780 RPM...................................................... 57

22 Ajuste das equações das curvas dos parâmetros da associação em paralelo dos dois conjuntos moto-bomba com diâmetro de rotor de 405 mm e 1780 RPM....... 58

23 Ajuste das equações das curvas dos parâmetros do conjunto moto-bomba com diâmetro de rotor de 377,9 mm e 1780 RPM.

24 Dimensionamento do sistema no sentido do fluxo da água, para cada trecho nos seis setores de funcionamento do sistema de irrigação.

25 Perda de carga, diâmetro da tubulação, classe de pressão, pressão de serviço na entrada da parcela e pressão ao longo dos trechos da tubulação calculados para os setores 1 e 2 ....

26 Perda de carga, diâmetro da tubulação, classe de pressão, pressão de serviço na entrada da parcela e pressão ao longo dos trechos da tubulação calculados para os setores 3 e 4 ..

27 Perda de carga, diâmetro da tubulação, classe de pressão, pressão de serviço na entrada da parcela e pressão ao longo dos trechos da tubulação calculados para os setores 5 e 6 ..

28 Gráfico comparativo entre classe de pressão e pressão no final do trecho da tubulação para simulação 1 ..

29 Gráfico comparativo entre classe de pressão e pressão no final do trecho da tubulação para simulação 2 ..

30 Gráfico comparativo entre classe de pressão e pressão no final do trecho da tubulação para simulação 3 ..

31 Gráfico comparativo entre classe de pressão e pressão no final dos trechos da tubulação para simulação 4 e variedade de laranja valência

32 Gráfico comparativo entre classe de pressão e pressão no final dos trechos da tubulação para simulação 4 e variedade de laranja hamlin 
33 Gráfico comparativo entre classe de pressão e pressão no final dos trechos da tubulação para simulação 4 e variedade de laranja pêra rio ...................................... 68

34 Gráfico comparativo entre classe de pressão e pressão no final dos trechos da tubulação para simulação 4 e variedade de laranja natal .......................................... 68 


\section{LISTA DE TABELAS}

Página

1 Classificação dos projetos de irrigação pelo método e dimensão da área

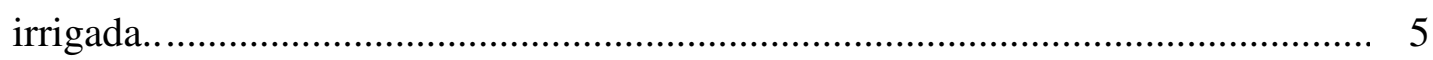

2 Valores da rugosidade absoluta equivalente de diferentes materiais.. .................... 11

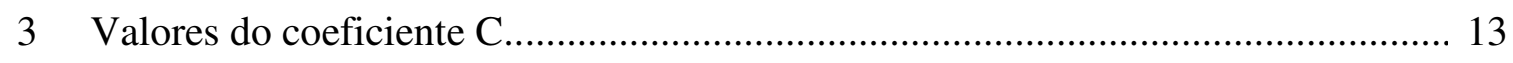

4 Margem de segurança para motores elétricos..................................................... 18

5 Área, espaçamento e número de plantas correspondentes às variedades

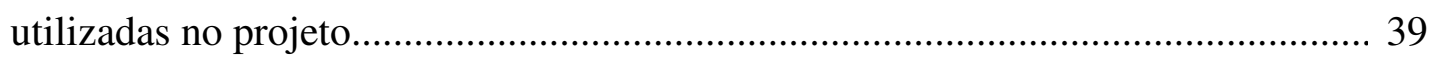

6 Dados técnicos do projeto de irrigação.............................................................. 40

7 Quadro de funcionamento dos blocos de irrigação............................................. 41

8 Distribuição das tubulações nos trechos do projeto............................................... 54

9 Parâmetros do conjunto moto-bomba Imbil ITAP 100-500/2 com diâmetro de

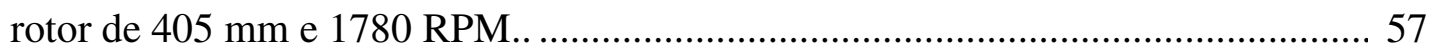

10 Parâmetros da associação em paralelo de dois conjuntos moto-bomba Imbil ITAP 100-500/2 com diâmetro de rotor de 405 mm e 1780 RPM........................... 58

11 Parâmetros do conjunto moto-bomba Imbil ITAP 100-500/2 com diâmetro de

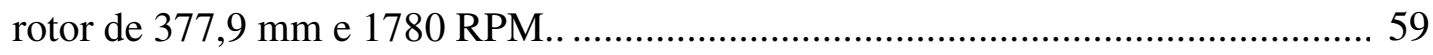




\section{LISTA DE SÍMBOLOS}

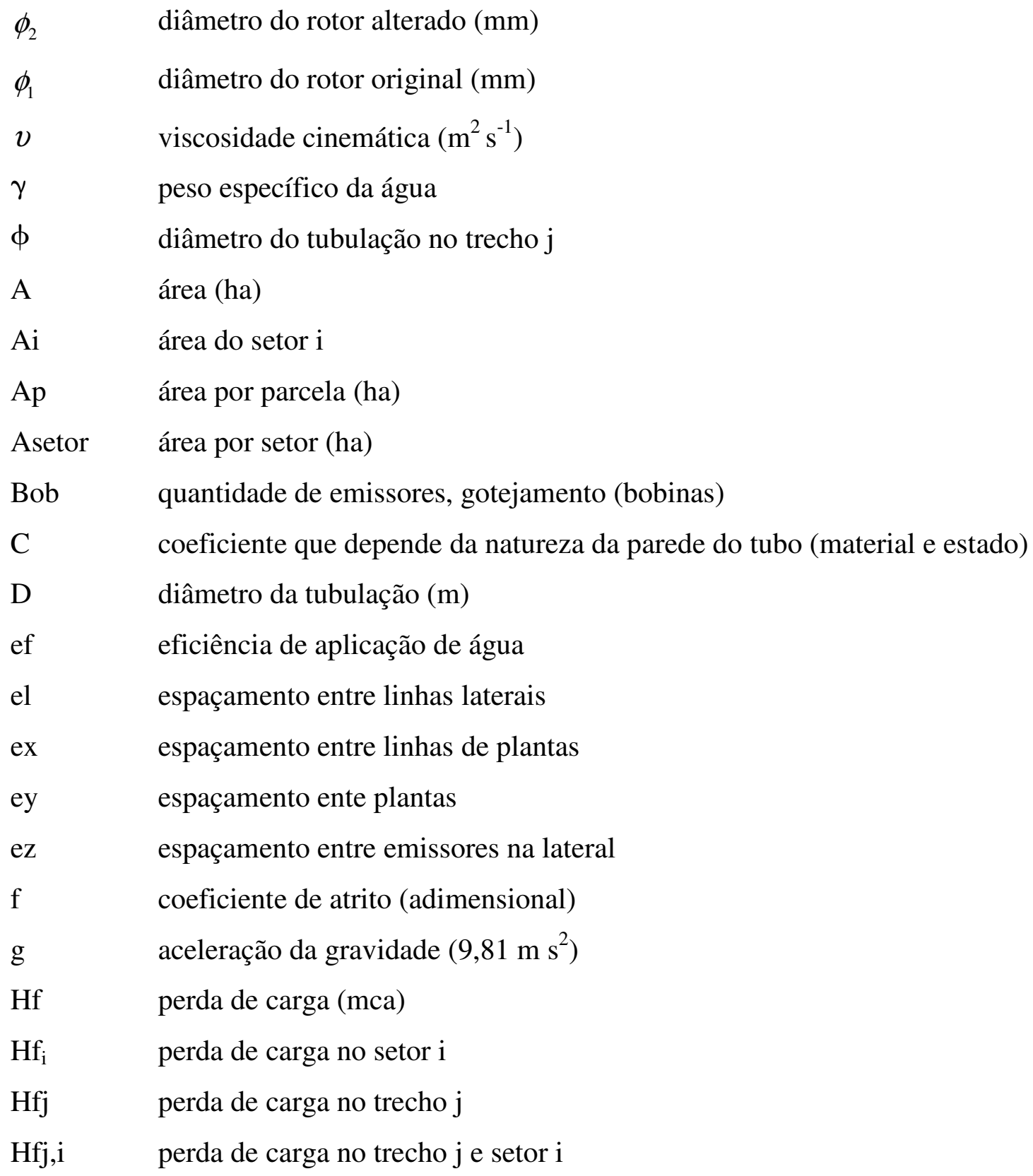




\begin{tabular}{|c|c|}
\hline $\mathrm{HmF}_{\mathrm{i}}$ & altura manométrica fornecida no setor i \\
\hline $\mathrm{Hm}_{\mathrm{j}}$ & altura manométrica simulada no trecho $\mathrm{j}$ \\
\hline $\mathrm{Hm}_{\mathrm{j}, \mathrm{i}}$ & altura manométrica no trecho $\mathrm{j}$ e setor $\mathrm{i}$ \\
\hline $\mathrm{HmR}_{\mathrm{i}}$ & altura manométrica requerida no setor i \\
\hline $\mathrm{Hmt}$ & altura manométrica total (mca) \\
\hline $\mathrm{Hmt}_{1}$ & altura manométrica no rotor original (mca) \\
\hline $\mathrm{Hmt}_{2}$ & altura manométrica no rotor ajustado (mca) \\
\hline Hmts & altura manométrica total simulada \\
\hline $\mathrm{J}$ & perda de carga unitária (mca) \\
\hline $\mathrm{K}$ & constante da fórmula de perda de carga \\
\hline $\mathrm{K}_{1}$ & constante de valor 1000 \\
\hline $\mathrm{K}_{2}$ & constante de valor 3600 \\
\hline $\mathrm{L}$ & comprimento da tubulação (m) \\
\hline Lam & lâmina de irrigação (mm) \\
\hline Lcalc & lâmina calculada (mm) \\
\hline Lliq & lâmina líquida de irrigação (mm) \\
\hline Lreq & lâmina de irrigação requerida (mm) \\
\hline $\mathrm{n}$ & rendimento da bomba (decimal) \\
\hline Nem & quantidade de emissores \\
\hline Nlat & quantidade de laterais \\
\hline Nmáx & número de setores máximo \\
\hline Npar & quantidade de parcelas \\
\hline Ns & número de setores de irrigação \\
\hline Nsetor & número do setor \\
\hline $\mathrm{P}$ & pressão \\
\hline $\mathrm{PE}$ & quantidade de tubulação lateral \\
\hline $\mathrm{Pj}, \mathrm{i}$ & pressão no trecho $\mathrm{j}$ e setor $\mathrm{i}$ \\
\hline Pmáx & pressão máxima \\
\hline Pot & Potência (cv) \\
\hline $\operatorname{Pot}_{1}$ & potência no rotor original (cv) \\
\hline
\end{tabular}


$\mathrm{Pot}_{2} \quad$ potência no rotor ajustado (cv)

Q vazão $\left(\mathrm{m}^{3} \mathrm{~s}^{-1}\right)$

q Vazão da tubulação $\left(1 \mathrm{~h}^{-1}\right)$

$\mathrm{Q}_{1} \quad$ vazão no rotor original $\left(\mathrm{m}^{3} \mathrm{~h}^{-1}\right)$

$\mathrm{Q}_{2} \quad$ vazão no rotor ajustado $\left(\mathrm{m}^{3} \mathrm{~h}^{-1}\right)$

$\mathrm{QF}_{\mathrm{i}} \quad$ vazão fornecida no setor $\mathrm{i}$

Qi vazão simulada no setor $\mathrm{i}$

$\mathrm{q}_{\mathrm{i}} \quad$ vazão do emissor

Qi,j Vazão no setor i e no trecho $\mathrm{j}$

$\mathrm{Q}_{\mathrm{j}} \quad$ vazão simulada no trecho $\mathrm{j}$

Qmáx vazão máxima

Qmin vazão mínima

Qp vazão por parcela $\left(\mathrm{m}^{3} \mathrm{~h}^{-1}\right)$

$\mathrm{QR}_{\mathrm{i}} \quad$ vazão requerida no setor $\mathrm{i}$

Qs vazão por setor $\left(\mathrm{m}^{3} \mathrm{~h}^{-1}\right)$

Qsim vazão simulada $\left(\mathrm{m}^{3} \mathrm{~h}^{-1}\right)$

Qt vazão por talhão / quadra $\left(\mathrm{m}^{3} \mathrm{~h}^{-1}\right)$

Re número de Reynolds

RPM rotações por minuto

$\mathrm{RPM}_{1} \quad$ rotação original

$\mathrm{RPM}_{2}$ rotação alterada

t jornada de trabalho diária

$\mathrm{T}$ torque do motor $(\mathrm{N} \mathrm{m})$

ts tempo de irrigação por setor (h)

Tx taxa de aplicação de água $\left(\mathrm{L} \mathrm{pl}^{-1}\right.$ dia $)$

$\mathrm{V} \quad$ velocidade média $\left(\mathrm{m} \mathrm{s}^{-1}\right)$

$\mathrm{V}_{\mathrm{j}} \quad$ velocidade simulada no trecho $\mathrm{j}$

$\mathrm{V}_{\mathrm{j}, \mathrm{i}} \quad$ velocidade no trecho $\mathrm{j}$ e setor $\mathrm{i}$

Vol volume aplicado por planta $\left(\mathrm{pl}^{-1} \mathrm{dia}\right)$

$\Delta \mathrm{zj} \quad$ diferença de nível no trecho j 

diferença de nível (m)

$\phi$ diâmetro da tubulação (mm)

$\gamma$ peso específico da água rendimento da bomba (decimal) 


\title{
DIMENSIONAMENTO E SIMULAÇÃO HIDRÁULICA DA IRRIGAÇÃO LOCALIZADA SOB CONDIÇÃO VARIÁVEL DE SETORES DE OPERAÇÃO
}

\author{
AUTOR: GUILHERME BUSI DE CARVALHO \\ Orientador: Prof. Dr. RUBENS DUARTE COELHO
}

\section{RESUMO}

Este trabalho teve como objetivo, desenvolver um programa computacional em linguagem Visual Basic Application ${ }^{\circledR}$ para dimensionamento da malha hidráulica de sistemas de irrigação localizada e simulação da operação em diferentes combinações de parcelas com funcionamento simultâneo (setores de operação), visando analisar o comportamento dos parâmetros dimensionais da malha hidráulica: vazão, velocidade da água, pressão real e nominal ao longo da tubulação, pressão de entrada no cavalete das parcelas e rendimento do conjunto moto-bomba. $\mathrm{O}$ modelo foi aplicado a um projeto hipotético de irrigação localizada por microaspersão com emissores autocompensantes na cultura de citros. As equações utilizadas para os cálculos da perda de carga foram Hazen-Williams e Darcy-Weisbach, podendo o usuário do aplicativo escolher entre as duas fórmulas para realizar as simulações desejadas. $\mathrm{O}$ aplicativo mostrou-se eficiente nos cálculos hidráulicos, permitindo ao usuário, por meio das simulações, escolher qual a combinação de parcelas de funcionamento associadas às características do conjunto moto-bomba e às necessidades do produtor em utilizar o sistema que melhor se ajusta ao projeto de irrigação. 


\title{
TRICKLE IRRIGATION DESIGN AND HIDRAULIC SIMULATION UNDER VARIABLE OPERATION CONDITION
}

\author{
Author: GUILHERME BUSI DE CARVALHO \\ Adviser: Prof. Dr. RUBENS DUARTE COELHO
}

\section{SUMMARY}

This work aims to present, a computational tool, developed in Visual Basic Application ${ }^{\circledR}$ language, applied to trickle irrigation network design and to simulate different block combinations operation (set of parcels operated at the same time), in order to analyze the network parameters behavior: flow, water speed, real and nominal pressure along the pipeline, parcel input pressure and pump parameters. The model was applied to a trickle irrigation hypothetical citrus project. The equations proposed to calculate head loss are Hazen-Williams and Darcy-Weisbach; users can choose between them to accomplish the hydraulics simulations desired. The application was shown efficient in the hydraulic calculations, allowing to the user, through the simulations, to choose which combination of parcels operation that better adjusted to the irrigation project and water management. 


\section{INTRODUÇÃO}

O sistema de irrigação localizada requer, normalmente, o maior investimento de capital para implantação, com possibilidade de proporcionar menor custo operacional ao longo dos anos; porém, precisa ser criteriosamente dimensionado, pois são muitas, as combinações, que podem resultar num projeto mais econômico (Maia, 1994).

Dessa forma, vários pesquisadores trabalharam com programação linear e não linear, entre outros métodos de pesquisa operacional, para auxiliar no dimensionamento econômico de sistemas de irrigação localizada em função do custo de aquisição e do custo operacional (Saad, 1993; Souza, 1993; Gomes, 1996; Silva, 1997; Matos, 2000). Entretanto como resultado desses trabalhos, em geral, os sistemas de irrigação localizada instalados baseados em minimização de custos, nem sempre são compatíveis em relação ao manejo da água e aos requerimentos agrícolas da cultura, assim como também ocorre com os projetos desenvolvidos pelas empresas de irrigação, cujo objetivo comercial aliado à falta de conhecimento por parte da maioria dos projetistas e dos produtores levam a um projeto econômico, porém, não operacional em condições de campo.

Diversas culturas, como as perenes, por exemplo, possuem, dentro de uma mesma área irrigada, plantas de diversas variedades associadas à porta-enxertos, espaçamentos e idades diferentes, que requerem quantidades e épocas de aplicação de água e fertilizantes distintas. Essa mesma área irrigada sofre ainda a interferência da variabilidade espacial dos solos no requerimento de lâminas de irrigação, em razão de suas propriedades físico-hídricas.

Portanto, quando há necessidade de alteração dos setores de funcionamento, em função do manejo agrícola da área irrigada, o produtor esbarra na falta de informações do projeto e de ferramentas de cálculo que forneçam suporte para uma rápida tomada de decisão em nível de campo. 
Em vista das dificuldades encontradas, nos programas de dimensionamento de sistemas de irrigação existentes, para realizar simulações de funcionamento, este trabalho teve como objetivo desenvolver uma ferramenta computacional em linguagem Visual Basic Applications $(\mathrm{VBA})^{\circledR} /$ Office $\mathrm{XP}^{\circledR} /$ Microsoft Excel ${ }^{\circledR}$ para dimensionamento e estudo de simulação de combinação de funcionamento das parcelas de irrigação e suas implicações nos parâmetros dimensionais da malha hidráulica (principal e secundária). O modelo foi aplicado a um projeto hipotético de irrigação localizada na cultura de citros, visando avaliar o potencial do projeto de irrigação em suprir adequadamente os requerimentos hídricos do manejo da irrigação em diferentes porções da área irrigada. 


\section{REVISÃO DE LITERATURA}

\subsection{A irrigação no contexto dos recursos hídricos}

Essencial à vida, a água, recurso finito de valor inestimável, é um elemento necessário a diversas atividades humanas, como geração de energia elétrica, abastecimento doméstico e industrial, irrigação, navegação, recreação, turismo, aqüicultura, piscicultura, pesca, assimilação e condução de esgoto, etc, tendo sua disponibilidade diminuída, gradativamente nos últimos tempos, devido ao crescimento populacional, à expansão das fronteiras agrícolas e à degradação do meio ambiente (Lima et al, 1999).

Para Thame (s.d.), o aquecimento da Terra, causado pela emissão de "gases de efeito estufa" na atmosfera, pode alterar o regime climático do planeta causando mortes de pessoas e seca de muitos rios em diversos países, podendo ser, portanto, um forte fator da diminuição dos recursos hídricos. Dentro deste contexto, Christofidis (2002a) cita também a distribuição não eqüitativa dos recursos hídricos como mais um problema ao abastecimento de água, já que cerca de $89,0 \%$ da potencialidade das águas superficiais do Brasil estão concentradas nas regiões Norte e Centro-Oeste e, os 11,0\% restantes estão concentrados nas outras três regiões (Nordeste, Sul e Sudeste), onde estão localizados $85,5 \%$ da população e $90,8 \%$ da demanda de água do país.

A previsão para o ano 2000, segundo Christofidis (2002a), mostrava a agricultura

como responsável pela maior parcela do uso consumptivo de água no mundo com $70,0 \%$, seguido pelo setor industrial com $22,0 \%$ e pelo consumo urbano com $8,0 \%$ do total consumido. Em relação ao Brasil, a divisão setorial do consumo consumptivo ficaria da seguinte forma: agrícola $(61,2 \%)$, urbano $(20,8 \%)$ e industrial $(18,0 \%)$. 
A agricultura irrigada é a principal responsável pelo consumo consumptivo da água dentro do setor agrícola, porém é uma técnica eficaz no aumento da produção de alimentos (Lima et al, 1999). Atualmente, estima-se que 55,0\% da água destinada à irrigação perde-se antes de atingir a zona radicular das culturas, devido às baixas eficiências na condução $(15,0 \%)$, distribuição $(15,0 \%)$ e aplicação $(25,0 \%)$ dos sistemas (Christofidis, 2002a); portanto, é aconselhável que se dê preferência por sistemas pressurizados de irrigação que utilizem a água de forma mais eficiente, como a irrigação localizada (gotejamento e microaspersão) e pivô central (LEPA).

Em vista do iminente risco de abastecimento de água em algumas regiões do planeta e do aumento na demanda por alimentos, há necessidade de se gerenciar de forma competente não apenas os recursos hídricos, mas todos os sistemas que envolvem o ciclo produtivo (principalmente a agricultura irrigada), como forma de garantir o desenvolvimento sustentável e a qualidade de vida da população.

\subsection{A irrigação localizada}

É um método de irrigação que aplica água ao solo diretamente sobre a zona radicular da cultura, em pequenas intensidades, porém com alta freqüência, mantendo sempre a umidade do solo próximo à capacidade de campo. A irrigação localizada pode ser classificada em gotejamento ou microaspersão, dependendo do tipo de emissor utilizado. Irriga sempre uma porção da superfície do solo, propiciando a formação de bulbos ou faixas molhadas. Os sistemas são fixos, existindo tantas linhas laterais quantas forem necessárias para suprir toda a área; porém, apenas determinado número de laterais funciona simultaneamente, com objetivo de diminuir a capacidade do cabeçal de controle (Bernardo, 1995), da malha hidráulica e do bombeamento.

\subsubsection{Crescimento da irrigação localizada}

A irrigação localizada foi o método com maior crescimento na área irrigada no Brasil entre os períodos de 1996 a 2001, passando de 4,24\% para 7,89\% (Christofidis, 2002b). Existe uma tendência deste crescimento perdurar, em função dos conflitos entre os diferentes usuários de água, da preocupação ambiental e da cobrança pelo uso da água prevista na Lei das Águas (Lei 9.443 de janeiro de 1997) (Lima et al, 1999), e da maior 
facilidade de crédito para aquisição de equipamentos e de licenciamento ambiental pelos órgãos competentes.

De acordo com Bonganha (2001), para os projetos já instalados, a legislação define um prazo máximo de dois anos para a regularização junto ao órgão ambiental. Para empreendimentos novos, o órgão licenciador expedirá a licença prévia (LP), licença de instalação (LI) e licença de operação (LO), sendo classificados em categorias (A, B e C) de acordo com a dimensão e o método de irrigação utilizado, conforme Tabela 1, priorizando os projetos que incorporem equipamentos e métodos mais eficientes, sendo a classificação decrescente em ordem de prioridade de instalação e de facilidade de licenciamento.

Tabela 1. Classificação dos projetos de irrigação pelo método e dimensão da área irrigada

\begin{tabular}{lccccc}
\hline $\begin{array}{c}\text { Método de } \\
\text { irrigação }\end{array}$ & Até 50,0 & $50,0-100,0$ & $100,0-500,0$ & $500,0-1000,0$ & Acima de \\
& & A & A (ha) & 1000,0 \\
\hline Aspersão & A & A & A & C & C \\
Localizada & A & B & B & C & C \\
Superficial & A & & & C
\end{tabular}

Fonte: Bonganha (2001).

Neste caso, a irrigação localizada leva vantagem em relação aos outros métodos devido à maior eficiência de aplicação de água (variando de $75 \%$ a 95\% contra $45 \%$ a $75 \%$ da irrigação por superfície, $60 \%$ a $90 \%$ da aspersão e $40 \%$ a $70 \%$ da irrigação por elevação do nível do lençol freático) e à menor demanda energética por operar em baixa pressão (1,0 a 3,5 $\mathrm{Kgf} \mathrm{cm}^{-2}$ ) (Christofidis, 2002b).

\subsubsection{Vantagens}

As principais vantagens do sistema de irrigação localizada, segundo Daker (1983), Bernardo (1995) e Vermeiren \& Jobling (1997), são as seguintes: 
a) Maior eficiência no uso da água: permite melhor controle da lâmina aplicada, diminui as perdas por evaporação, por percolação ou por escorrimento superficial, não irriga entre as linhas de plantio e não provoca perdas por deriva e por interferência do irrigante.

b) Maior produtividade: para culturas que respondem à maior umidade no solo, pois a alta freqüência de irrigação é inerente do método.

c) Maior eficiência na adubação: permite a fertirrigação e, em razão de concentrar o sistema radicular da cultura junto ao bulbo molhado, facilita a aplicação do adubo por cobertura.

d) Maior eficiência no controle fitossanitário: não molha a parte aérea das plantas, nem irriga as plantas daninhas.

e) Não interfere nas práticas culturais: como não molha toda a faixa entre as fileiras, pode-se executar as práticas culturais antes, durante e após as irrigações.

f) Adapta-se a diferentes tipos de solo e topografia: como a intensidade de aplicação de água é pequena, este método adapta-se melhor a diferentes tipos de solo e topografia.

g) Pode ser usado com água salina ou em solos salinos: como a freqüência de irrigação é alta, a umidade no bulbo molhado é sempre alta, mantendo a concentração de sais diluída dentro do bulbo e maior na sua periferia.

h) Economia de mão-de-obra: por se tratar de sistemas fixos, há uma economia de mão-de-obra quando comparada com sistemas convencionais de irrigação por aspersão e superfície.

i) Redução dos gastos de energia: a pressão necessária para a irrigação localizada é em geral igual a 50,0 - 70,0\% daquela necessária para a irrigação por aspersão clássica, permitindo instalação de menores potências. Portanto, é necessário que haja muito cuidado na elaboração dos projetos para que as vantagens teóricas do sistema se tornem realidade, pois com objetivo de reduzir o custo de aquisição muitos projetos operam com pressões comparadas às dos sistemas por aspersão convencional, principalmente quando utilizam emissores autocompensantes, distorcendo o princípio do método. 
j) Automação: pode-se, por meio de sensores de umidade de solo, medidores de volume e de tempo, iniciar ou finalizar um turno de irrigação automaticamente.

\subsubsection{Desvantagens}

As principais desvantagens do método, segundo Daker (1983), Bernardo (1995) e Vermeiren \& Jobling (1997), são:

a) Entupimento: como os orifícios de saída dos emissores são pequenos (0,5 a 1,5 $\mathrm{mm}$ ), em razão da baixa vazão, o sistema exige sistemas de filtragem para assegurar uma qualidade mínima de água. Porém, o depósito de argila e silte em suspensão na água, a precipitação de sais e íons e o desenvolvimento de microrganismos dentro da tubulação após a filtragem podem fazer com que o problema de entupimento perdure;

b) Distribuição do sistema radicular: tende a concentrar-se na zona úmida do solo, reduzindo sua área de abrangência;

c) Salinização: as aplicações de água e adubo são realizadas em apenas uma porção da área de exploração da cultura, em regiões de baixa precipitação pluviométrica, esse risco se acentua;

d) Controle atmosférico: a irrigação localizada não permite proteger as culturas do frio e das geadas;

e) Custo de aquisição: os sistemas de irrigação localizada possuem custo de aquisição mais elevado em comparação aos outros métodos de irrigação para as mesmas condições de projeto.

Um sistema de irrigação localizada não deve permanecer por um tempo prolongado (mais de 1 mês) sem funcionamento; isto promove um conjunto de problemas que podem inviabilizar o funcionamento do sistema. Ao desligar a irrigação, seja durante o período das chuvas ou durante os períodos de estresse hídrico, no caso da cafeicultura e da citricultura, por exemplo, os microorganismos dentro do sistema encontram condições ideais para seu desenvolvimento e formam grandes placas de colônias ou filamentos, que ao reiniciar o período de irrigação se desprendem da tubulação e entopem os emissores, emperram as válvulas e obstruem a malha de microtubo da automação. 


\subsubsection{Características dos componentes do sistema}

Os componentes do sistema segundo Daker (1983), Bernardo (1995) e Vermeiren \& Jobling (1997), são: conjunto moto-bomba, cabeçal de controle, rede de distribuição e emissores.

O conjunto moto-bomba, responsável pela pressurização do sistema, geralmente é do tipo centrífuga de eixo horizontal movida à energia elétrica ou motores diesel.

O cabeçal de controle é constituído de sistema de filtragem (filtros de areia, tela, disco, mantas não tecidas, separadores de sólidos), com limpeza automática (diferencial de pressão ou tempo) ou manual; medidores de vazão, de fundamental importância, pois permitem identificar problemas de entupimento; válvulas de controle de pressão e vazão, permitem automação do sistema; sistema de injeção de fertilizantes; sistema de automação; sistema de segurança: composto por válvulas ventosas e válvulas de alívio de pressão e ou antecipadoras de golpe de Aríete.

A rede de distribuição é composta de tubulação principal e suas ramificações (secundárias e terciárias), responsáveis por conduzir a água da moto-bomba às tubulações de derivação, podendo ser de PVC, polietileno de alta ou média densidade, aço galvanizado ou zincado e fibrocimento entre outros, tubulações de derivação, responsáveis pela distribuição da água para as tubulações laterais, geralmente são de PVC e polietileno de alta e média densidade, tubulações laterais, responsáveis por distribuir a água para os emissores, são sempre de polietileno de baixa densidade, com exceção de algumas instalações que utilizam PVC de pequeno diâmetro (estufas e viveiros de mudas). As tubulações de derivação e lateral fazem parte das parcelas de irrigação, que são as subdivisões da área. Cada parcela é responsável pela irrigação de uma porção da área, com tamanho e forma dependente da topografia do terreno, da geometria da área, do tipo e modelo do emissor e do layout desejado pelo projetista. Os conjuntos de parcelas de irrigação do projeto que operam simultaneamente formam os setores de irrigação.

Os emissores, que constituem a parte essencial da instalação, derivam a água ou vazões pequenas e constantes à pressão atmosférica, podem ser gotejadores, microaspersores, microtubos, orifícios de pequena vazão, etc. 


\subsection{Hidráulica da irrigação localizada}

Como o objetivo do trabalho é verificar os efeitos das alterações da combinação de funcionamento dos setores de irrigação na malha hidráulica principal do sistema, a revisão não contempla os fundamentos hidráulicos das tubulações de derivação e lateral e dos emissores.

\subsubsection{Concepção de projeto}

Um projeto de irrigação localizada pode, ao ser dimensionado, ter inúmeras combinações de tipos e características de emissão de água pelos emissores, associados com diferentes traçados de tubulação, diferentes divisões de parcelas e setores, tipos de materiais utilizados nas diversas tubulações do sistema, tipos e associações de motobombas, diversidade nos comprimentos de linhas laterais, entre muitas outras características dos componentes do sistema. Dessa forma o projeto é totalmente dependente da interpretação humana, que por sua vez depende da capacidade intelectual, da experiência e do conhecimento do projetista, e dos recursos da ferramenta utilizada para executá-lo da melhor forma possível.

\subsubsection{Hidráulica de tubulação principal}

\subsubsection{Fórmula de Darcy-Weisbach (Universal)}

Segundo Vermeiren \& Jobling (1997), devido à viscosidade, o fluxo numa tubulação pode ser laminar ( $\operatorname{Re}<2000)$, turbulento $(\operatorname{Re}>4000)$ ou uma combinação de ambos na zona crítica $(2000 \leq \mathrm{Re} \leq 4000)$. O critério que distingue os dois regimes foi determinado por Reynolds (Re), que lhe conferiu seu nome, e em condutos circulares sob pressão, este adimensional se expressa pela equação 1:

$$
\mathrm{R}_{\mathrm{e}}=\frac{\mathrm{V} \cdot \mathrm{D}}{\mathrm{K}_{1} \cdot \mathrm{v}}
$$

\section{Em que:}

$\mathrm{V}$ - velocidade média $\left(\mathrm{m} \mathrm{s}^{-1}\right)$;

D - diâmetro interno da tubulação (mm); 
$\mathrm{K}_{1}$ - constante de valor 1000 ;

$v$ - viscosidade cinemática $\left(\mathrm{m}^{2} \mathrm{~s}^{-1}\right)$.

Expressando-se em função da vazão, tem-se a equação 2.

$$
\mathrm{R}_{\mathrm{e}}=\frac{4 \cdot \mathrm{q}}{\mathrm{K}_{2} \cdot v \cdot \pi \cdot \mathrm{D}}
$$

Em que:

q - vazão da tubulação $\left(1 \mathrm{~h}^{-1}\right)$;

$\mathrm{K}_{2}$ - constante de valor 3600 .

A fórmula de Darcy-Weisbach, que expressa o valor da perda de carga em função da vazão, é expressa pela equação 3:

$\mathrm{Hf}=\frac{8 \cdot \mathrm{f} \cdot \mathrm{Q}^{2} \cdot \mathrm{L}}{\pi^{2} \cdot \mathrm{g} \cdot \mathrm{D}^{5}}$

Em que:

Hf - perda de carga (mca);

f - coeficiente de atrito (adimensional);

$\mathrm{Q}$ - vazão, $\left(\mathrm{m}^{3} \mathrm{~s}^{-1}\right)$;

L - comprimento da tubulação (m);

g - aceleração da gravidade $\left(9,81 \mathrm{~m} \mathrm{~s}^{2}\right)$;

D - diâmetro interno da tubulação (m).

O fator de atrito f depende do número de Reynolds, que por sua vez depende do regime de escoamento da água dentro da tubulação, ou seja, laminar, transição ou turbulento, e da rugosidade relativa da tubulação (equação 4).

Rugosidade relativa $=\left(\frac{\varepsilon}{\mathrm{D}}\right)$

Em que:

$\varepsilon$ - rugosidade absoluta ou altura das asperezas nas paredes do conduto (m). 
A Tabela 2 apresenta os valores da rugosidade absoluta equivalente para os principais materiais utilizados em projetos de condução de água.

Tabela 2. Valores da rugosidade absoluta equivalente de diferentes materiais

\begin{tabular}{lc}
\hline \multicolumn{1}{c}{ Material } & Rugosidade absoluta equivalente $(\varepsilon, \mathrm{mm})$ \\
\hline Aço soldado novo & 0,05 a 0,10 \\
Aço soldado moderadamente oxidado & 0,40 \\
Aço galvanizado sem costura & 0,06 a 0,15 \\
Ferro fundido novo & 0,25 a 0,50 \\
Ferro fundido velho & 3,00 a 5,00 \\
Concreto com acabamento normal & 1,00 a 3,00 \\
PVC, plásticos em geral, tubos extrudados & 0,0015 a 0,010
\end{tabular}

Fonte. Adaptado de Porto, 2001.

Segundo Porto (2001), a especificação da rugosidade da tubulação, normalmente apresentada em tabelas para diversos materiais com ampla variação de valores, e a previsão de sua modificação com o tempo, devido à alteração da superfície da parede, coloca o projetista diante de um problema de difícil determinação, exigindo bom senso e experiência.

Quando o regime é laminar, f é função apenas do número de Reynolds e independe da rugosidade $(\varepsilon)$, nesse caso o seu valor é dado pela equação 5, de HagenPoiseuille (Cruciani, 1996):

$$
f=\frac{64}{\operatorname{Re}}
$$

Quando o regime é turbulento, f passa a depender do Número de Reynolds (Re) e da rugosidade relativa $(\varepsilon)$, até chegar ao extremo de depender exclusivamente da rugosidade relativa $(\varepsilon)$, quando o regime é fortemente turbulento (Cruciani, 1996):

Para a situação de condutos lisos e regime turbulento, quando a rugosidade da parede $(\varepsilon)$ é menor que a espessura da camada limite ou camada viscosa aderente o coeficiente f se expressa pela equação 6, de Blasius $(3000<\operatorname{Re}>100000)$. 
$\mathrm{f}=0,316 \cdot \mathrm{Re}^{-0,25}$

Para a situação de tubos rugosos e regime turbulento, o fator $\mathrm{f}$ pode ser determinado por meio das fórmulas desenvolvidas por Colebrook-White (equação 7) e pela equação analítica correspondente ao Diagrama de Moody (equação 8).

$$
\begin{aligned}
& \frac{1}{\sqrt{\mathrm{f}}}=-2 \log \left(\frac{\varepsilon}{3,7 \cdot \mathrm{D}}\right)+\left(\frac{2,51}{\mathrm{Re} \cdot \sqrt{\mathrm{f}}}\right) \\
& \mathrm{f}=0,0055\left[1+\left(20000 \frac{\varepsilon}{\mathrm{D}}+\frac{1 \times 10^{-6}}{\mathrm{Re}}\right)^{\frac{1}{3}}\right]
\end{aligned}
$$

Para a situação de condutos rugosos e turbulência completa, o fator $\mathrm{f}$ pode ser determinado pela equação 9, de Nikuradse.

$$
\frac{1}{\sqrt{\mathrm{f}}}=1,74-2 \log \left(\frac{2 \varepsilon}{\mathrm{D}}\right)
$$

Na hidráulica dos sistemas de irrigação localizada não se pode empregar diretamente as fórmulas teóricas para o cálculo exato do objeto em estudo, pois, como no caso das tubulações, existem vários fatores que influenciam na circulação da água, como por exemplo, a rugosidade, que varia com o tempo de uso, a pureza da água que devido ao teor de sais, interfere na viscosidade do fluido e os tipos de juntas que podem causar obstruções à passagem da água. Portanto, deduz-se que para se utilizar corretamente estas fórmulas é preciso corrigi-las por meio de coeficientes obtidos na prática. A fórmula obtida por Hazen-Williams, por ser resultado de estudo estatístico cuidadoso e ser amplamente aprovada na prática (Daker, 1983), juntamente com a fórmula de Darcy-Weisbach, por ser um modelo fisicamente fundamentado foram utilizadas para execução dos cálculos deste trabalho. 


\subsubsection{Fórmula de Hazen-Williams}

Segundo Bernardo (1995), a fórmula é recomendada para água a temperatura ambiente e para diâmetro igual ou superior a $50 \mathrm{~mm}$, e se expressa pela equação 10 .

$$
\mathrm{J}=10,646 \cdot \frac{1}{\mathrm{D}^{4,87}} \cdot\left(\frac{\mathrm{Q}}{\mathrm{C}}\right)^{1,852}
$$

Em que:

$\mathrm{J}$ - perda de carga unitária $\left(\mathrm{m} \mathrm{m}^{-1}\right)$;

D - diâmetro da tubulação (m);

$\mathrm{Q}$ - vazão $\left(\mathrm{m}^{3} \mathrm{~s}^{-1}\right)$;

C - coeficiente que depende da natureza da parede do tubo (material e estado).

A Tabela 3 mostra os valores do coeficiente $\mathrm{C}$ para os principais materiais utilizados na condução de água.

Tabela 3. Valores do coeficiente C

\begin{tabular}{lc}
\hline \multicolumn{1}{c}{ Material } & Valor de C \\
\hline Aço galvanizado novo & 125 \\
Aço soldado novo & 120 \\
Aço soldado em uso & 90 \\
Cimento-amianto & 140 \\
Ferro fundido novos & 130 \\
Ferro fundido em uso & 90 \\
Concreto acabamento bom & 130 \\
Plástico & 140 \\
\hline
\end{tabular}

Fonte: Azevedo Netto \& Alvarez, 1988.

Porto (2001), apresentou um estudo comparativo entre os coeficientes de rugosidade propostos por Hazen-Williams em função do número de Reynolds (faixa de $10^{4}$ a $10^{7}$ ), para diâmetros de 50,100, 150 e $200 \mathrm{~mm}$ e quatro tipos de rugosidade absoluta: rigorosamente liso, $\varepsilon=0,0 \mathrm{~mm}, \mathrm{PVC}, \varepsilon=0,005 \mathrm{~mm}$, aço laminado novo, $\varepsilon=$ 0,05 e tubo rugoso, $\varepsilon=0,5 \mathrm{~mm}$. $\mathrm{O}$ autor concluiu que o coeficiente de rugosidade $\mathrm{C}$, além de depender do diâmetro, é afetado pelo grau de turbulência, não caracterizando 
uma categoria de tubos, como especificado nas tabelas que acompanham a fórmula de Hazen-Williams; portanto, deve ser vista com reservas em problemas de condução de água, que pela sua importância, exige avaliação rigorosa das perdas de carga e, diante da incerteza sobre o tipo de escoamento turbulento, deve-se utilizar a fórmula universal, com coeficiente de atrito determinado pela equação 7 .

A utilização das fórmulas práticas experimentais deve ser realizada com muito critério, observando as condições para qual elas foram determinadas.

\subsection{Bombeamento}

\subsubsection{Bombas hidráulicas}

De acordo com Denículi (2001), as bombas hidráulicas são máquinas que recebem trabalho mecânico e o transformam em energia hidráulica, fornecendo energia ao líquido. Podem ser classificadas em volumétricas e turbo-bombas ou bombas hidrodinâmicas.

As bombas volumétricas são bombas de pistão ou de diafragma, em que o órgão (rotor) fornece energia ao líquido em forma de pressão;

Nas turbo-bombas ou bombas hidrodinâmicas o órgão (rotor) fornece energia ao líquido em forma de energia cinética, sempre com movimento rotativo. Podem ser classificadas quanto à: a) Trajetória do fluido dentro do rotor: radiais ou centrífugas, axiais e diagonais ou de fluxo misto; b) Número de entradas para aspiração ou sucção: simples e de dupla sucção; c) Número de rotores dentro da carcaça: simples estágio ou unicelulares e múltiplos estágios ou multicelulares; e) Posicionamento do eixo: horizontal e vertical; f) Pressão desenvolvida: baixa pressão (menor ou igual a $150 \mathrm{KPa}$ ), média pressão (entre 150 e $500 \mathrm{KPa}$ ) e alta pressão (acima de $500 \mathrm{KPa}$ ); g) Tipo de rotor: aberto, fechado e semi-fechado; h) Posição da bomba em relação ao nível da água: sucção positiva e sucção negativa ou afogada.

\subsubsection{Seleção de Bombas}

Cada tipo de bomba possui uma relação entre vazão (Q), altura manométrica (Hmt), potência absorvida (Pot), velocidade de rotação (RPM) e rendimento ( $)$ que, 
associadas, formam as curvas características específicas de cada modelo de bomba e podem ser alteradas em função da rotação e do diâmetro do rotor por meio das equações 11, 12 e 13, (Porto, 2001).

$$
\begin{aligned}
& \mathrm{Q}_{2}=\frac{\mathrm{Q}_{1}}{\left[\left(\frac{\mathrm{RPM}_{1}}{\mathrm{RPM}_{2}}\right) \cdot\left(\frac{\phi_{1}}{\phi_{2}}\right)^{3}\right]} \\
& \mathrm{Hmt}_{2}=\frac{\mathrm{Hmt}_{1}}{\left[\left(\frac{\mathrm{RPM}_{1}}{\mathrm{RPM}_{2}}\right)^{2} \cdot\left(\frac{\phi_{1}}{\phi_{2}}\right)^{2}\right]} \\
& \mathrm{Pot}_{2}=\frac{\mathrm{Pot}_{1}}{\left[\left(\frac{\mathrm{RPM}_{1}}{\mathrm{RPM}_{2}}\right)^{3} \cdot\left(\frac{\phi_{1}}{\phi_{2}}\right)^{5}\right]}
\end{aligned}
$$

Em que:

$\mathrm{Q}_{1}$ - vazão no rotor original $\left(\mathrm{m}^{3} \mathrm{~h}^{-1}\right)$;

$\mathrm{Q}_{2}$ - vazão no rotor ajustado $\left(\mathrm{m}^{3} \mathrm{~h}^{-1}\right)$;

$\mathrm{RPM}_{1}$ - rotação original;

$\mathrm{RPM}_{2}$ - rotação alterada;

$\phi_{1}$ - diâmetro do rotor original (mm);

$\phi_{2}$ - diâmetro do rotor alterado (mm);

$\mathrm{Hmt}_{1}$ - altura manométrica no rotor original (mca);

$\mathrm{Hmt}_{2}$ - altura manométrica no rotor ajustado (mca);

Pot $_{1}$ - potência no rotor original (cv);

$\mathrm{Pot}_{2}$ - potência no rotor ajustado (cv).

Mantendo-se constantes a forma e a velocidade de rotação do motor a divisão entre as rotações das equações 11,12 e 13 se anulam e a variação no diâmetro do rotor dá origem a curvas características paralelas (Bernardo, 1995), que podem ser calculados por meio das equações, 14, 15 e 16 (Porto, 2001). 
$\mathrm{Q}_{2}=\frac{\mathrm{Q}_{1}}{\left[\left(\frac{\phi_{1}}{\phi_{2}}\right)^{3}\right]}$

$\mathrm{Hmt}_{2}=\frac{\mathrm{Hmt}_{1}}{\left[\left(\frac{\phi_{1}}{\phi_{2}}\right)^{2}\right]}$

$\operatorname{Pot}_{2}=\frac{\operatorname{Pot}_{1}}{\left[\left(\frac{\phi_{1}}{\phi_{2}}\right)^{5}\right]}$

Mantendo constante a forma e o diâmetro do rotor a divisão entre os diâmetros dos rotores das equações 11, 12 e 13 se anulam, permitindo, por meio da alteração na rotação, obter novos pontos de operação, sendo recomendada, na prática, uma variação na ordem de 30,0 a 40,0\%, no máximo, para que o rendimento seja considerado aproximadamente o mesmo (Denículi, 2001). Desta forma as equações 17, 18 e 19 permitem o cálculo da vazão, altura manométrica e potência alteradas, respectivamente, devido à variação na rotação

$$
\begin{aligned}
& \frac{\mathrm{Q}_{1}}{\mathrm{Q}_{2}}=\left(\frac{\mathrm{RPM}_{1}}{\mathrm{RPM}_{2}}\right) \\
& \frac{\mathrm{Hmt}_{1}}{\mathrm{Hmt}_{2}}=\left(\frac{\mathrm{RPM}_{1}}{\mathrm{RPM}_{2}}\right)^{2} \\
& \frac{\mathrm{Pot}_{1}}{\mathrm{Pot}_{2}}=\left(\frac{\mathrm{RPM}_{1}}{\mathrm{RPM}_{2}}\right)^{3}
\end{aligned}
$$

Quando o rotor de uma bomba é usinado, com objetivo de diminuição de vazão e/ou de pressão, a semelhança geométrica é anulada, portanto é recomendada uma redução máxima de $20,0 \%$ do diâmetro original para que o rendimento não seja afetado significativamente (Denículi, 2001) . 


\subsubsection{Cálculo da potência}

A potência necessária ao motor para atender às condições de operação da bomba é calculada por meio da equação 20 .

Potência $=\frac{\gamma \cdot \mathrm{Q} \cdot \mathrm{Hmt}}{75 \cdot \mathrm{n}}$

Em que:

$\mathrm{Q}$ - vazão $\left(\mathrm{m}^{3} \mathrm{~s}^{-1}\right)$;

Hmt - altura manométrica total (mca);

$\eta$ - rendimento da bomba (decimal).

Por outro lado possuindo os dados de vazão $\left(\mathrm{Q}, \mathrm{m}^{3} \mathrm{~h}^{-1}\right)$, pressão (Hmt, mca), potência (Pot, cv) e rotação (RPM) é possível calcular o rendimento da bomba, equação $21(\eta, \%)$ e o torque do motor, equação $22(\mathrm{~T}, \mathrm{~N}$ m), muito importante para ajustar o consumo dos motores diesel no ponto mais econômico.

$$
\begin{aligned}
& \eta=\frac{\mathrm{Q} \cdot \mathrm{Hmt}}{2,7 \cdot \mathrm{Pot}} \\
& \mathrm{T}=\frac{\mathrm{Pot} \cdot 736 \cdot 60}{2 \cdot \pi \cdot \mathrm{RPM}}
\end{aligned}
$$

\subsection{Seleção de motores}

Os principais tipos utilizados em irrigação são os motores movidos a energia elétrica e a óleo diesel.

\subsubsection{Motores elétricos}

Na seleção de motores elétricos deve-se considerar uma folga, ou margem de segurança, na potência. Esta folga é importante para evitar que o motor opere com sobrecarga. A Tabela 4 mostra a recomendação da folga em função da faixa de potência exigida pela bomba. 
Tabela 4. Margem de segurança para motores elétricos

\begin{tabular}{lc}
\hline \multicolumn{1}{c}{ Potência exigida pela bomba (cv) } & $\begin{array}{c}\text { Margem de segurança recomendável para } \\
\text { motores elétricos }\end{array}$ \\
\hline até 2,0 & $50,0 \%$ \\
2,0 a 5,0 & $30,0 \%$ \\
5,0 a 10,0 & $20,0 \%$ \\
10,0 a 20,0 & $15,0 \%$ \\
acima de 20 & $10,0 \%$ \\
\hline
\end{tabular}

Fonte: Denículi (2001).

Segundo Bernardo (1995), a margem de segurança para motores com potência até $2,0 \mathrm{cv}$ deve ser de $30,0 \%$ e, entre 2,0 e 5,0 cv de 25,0\%, nas outras faixas os valores coincidem com os apresentados na Tabela 4.

\subsubsection{Motores diesel}

Segundo Mialhe (1996), o consumo de combustível representa parcela ponderável dos custos operacionais do projeto, portanto, é de fundamental interesse o conhecimento das características operacionais associadas diretamente com o consumo, visando a utilização do motor na faixa econômica. Para isso, primeiramente, é necessário o gráfico que contém as "curvas topográficas" de desempenho do motor (Figura 1), também denominadas curvas de isoconsumo ou de isorendimento. Esse gráfico contém uma família de curvas que indica a dependência do consumo específico constante de combustível e, por conseqüência, do rendimento constante, em relação ao torque solicitado e correspondente rotação (RPM). 


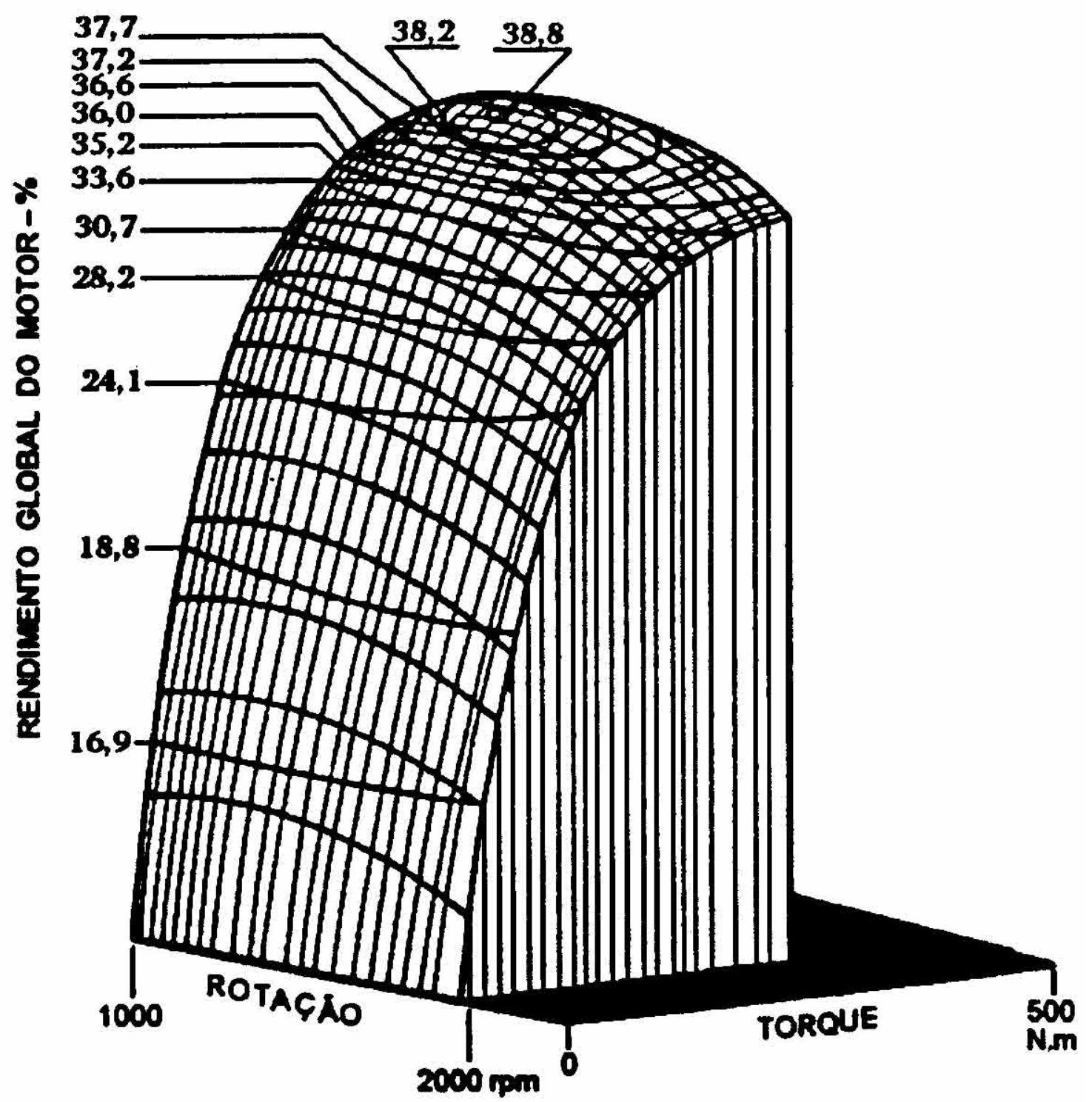

Figura 1 - Curvas topográficas do motor MWM em gráfico tridimensional do mapa de desempenho

Fazendo dois cortes no gráfico (Figura 2); um longitudinal (corte "AA"), mantendo a rotação fixa e o torque variável, verifica-se que, o aumento do torque faz com que o rendimento global aumente, até um valor máximo, e depois diminua, mesmo com o contínuo aumento do torque; e outro transversal (corte "BB"), mantendo o torque fixo e a rotação variável, verifica-se que a redução da rotação, pela diminuição da 
alavanca do acelerador, no motor submetido a torque constante provocou aumento gradativo do rendimento global.

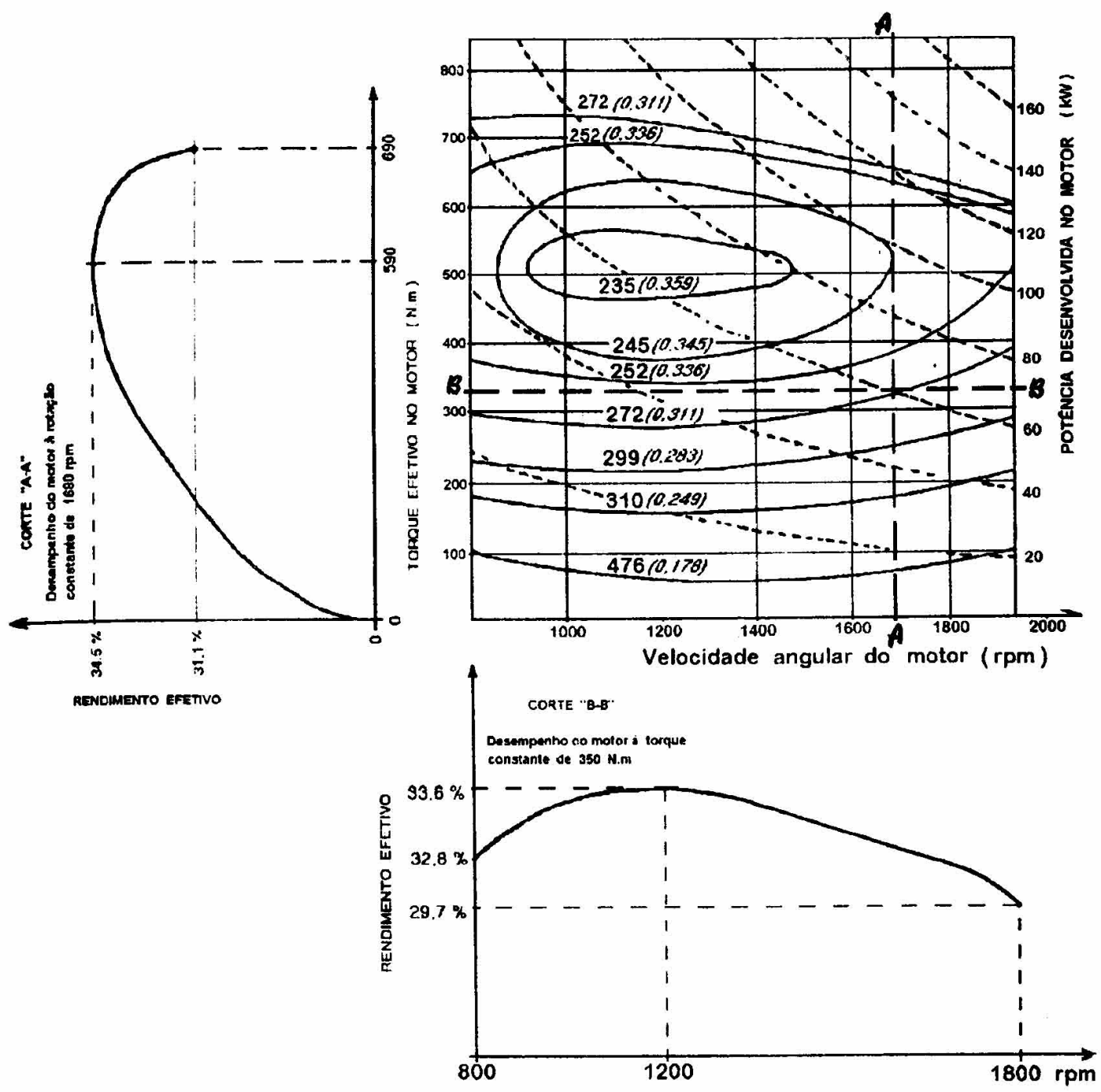

Figura 2 - Mapa de desempenho de motor diesel e perfil das curvas do corte "AA" para rotação fixa e do corte "BB" para torque fixo

O segundo passo para utilização do motor na faixa econômica é a determinação da curva de otimização operacional (Figura 3), ou seja, a curva traçada pelos pontos que representam a intersecção das curvas de isopotência com as curvas de menor isoconsumo. A linha que une esses pontos constitui o limite da combinação de torque e velocidade, para o qual se obtêm o consumo mínimo e o rendimento máximo possíveis 
de serem alcançados nessas condições operacionais, de outra forma, seria a combinação entre relação de transmissão e posição da alavanca do acelerador. No caso da irrigação (conjunto moto-bomba), o ponto de menor isoconsumo seria dado pela combinação entre diâmetro de rotor e rotação.

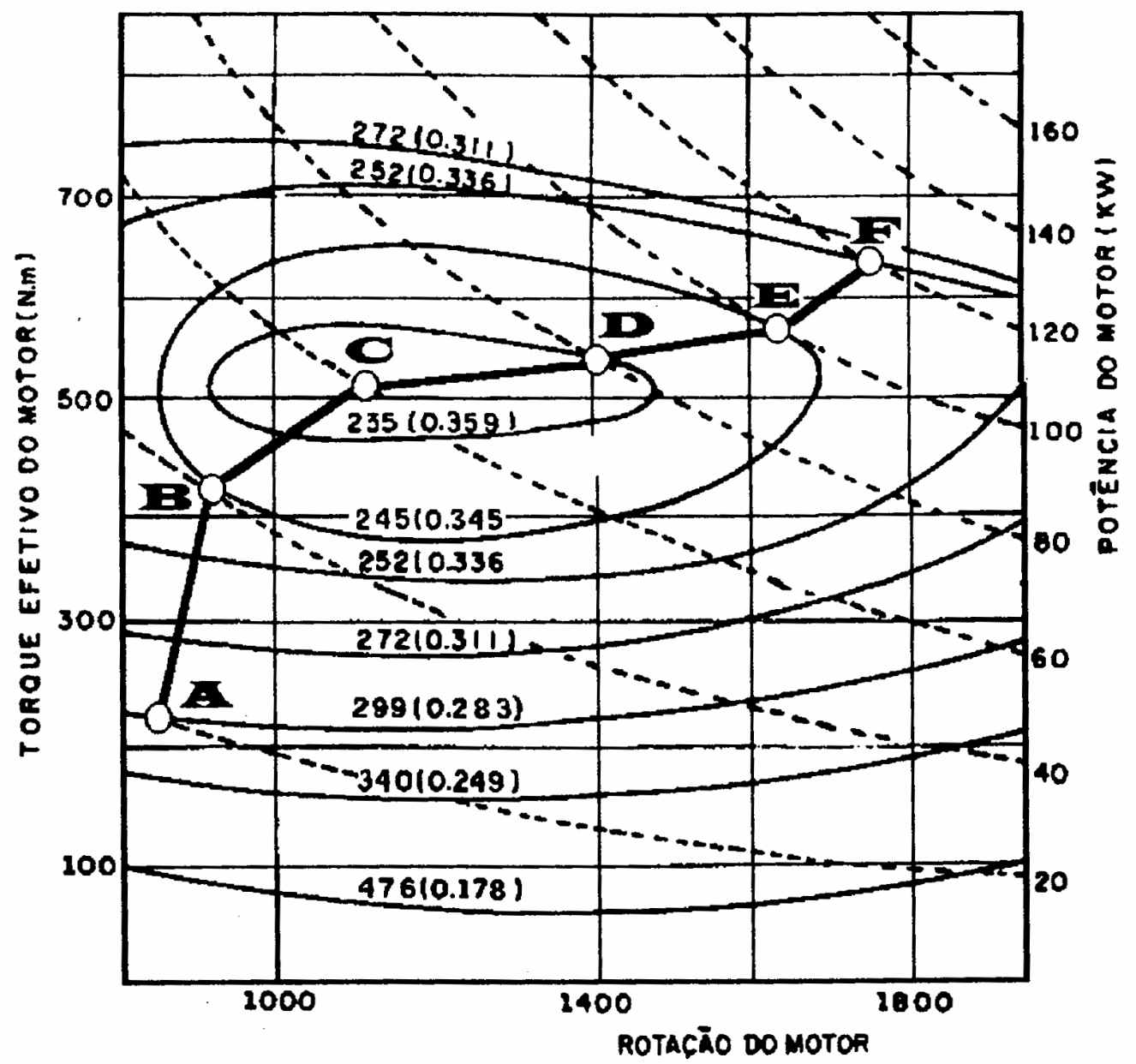

Figura 3 - Curva de otimização operacional, traçada sobre o mapa de desempenho de motor diesel da Figura 2

\subsection{Otimização de projetos}

Conforme estudo realizado pela CEMIG (1993) (Companhia de Energia Elétrica de Minas Gerais), se a irrigação fosse utilizada de forma racional, cerca de 20,0\% da água e $30,0 \%$ da energia consumida seriam economizadas, sendo $20,0 \%$ da energia 
economizada devido à aplicação desnecessária da água e 10,0\% devido ao redimensionamento e otimização dos equipamentos utilizados para a irrigação.

Em vista disso, o planejamento agrícola apresenta-se como uma técnica para a racionalização da locação dos recursos disponíveis para a produção, de maneira que os mesmos possam ser utilizados na sua forma ótima. Assim sendo, a irrigação não deve ser considerada apenas como uma técnica para adicionar água ao solo, e sim como um conjunto de técnicas que devem ser adotadas de maneira a proporcionar a umidade ao solo para atender da maneira mais econômica possível às necessidades de água das culturas (Souza et al., 1998).

Segundo Allen \& Brockway (1984), novos e antigos conceitos de melhoria no uso e na eficiência da irrigação e da maximização da receita devem ser utilizados no dimensionamento de novos sistemas de irrigação com objetivo de redução do uso de energia. Porém, o benefício econômico é o maior critério para determinação da aceitabilidade das alterações no dimensionamento e no manejo da irrigação. Para tal, análises econômicas e financeiras devem ser implementadas, como projeção de fluxo de caixa, previsão de alta e baixa do preço dos produtos e variação no preço de commodity entre outras, além da necessidade dos engenheiros estarem informados sobre os avanços tecnológicos visando conciliar alternativas para redução de custos operacionais, com maximização da receita.

Dentre os métodos de planejamento a programação linear é um método que tem grande aplicação (Souza et al., 1998), assim como a programação não linear, programação dinâmica, o uso de funções de múltiplas variáveis, elementos finitos (Matos, 2000), entre outras.

\subsubsection{Programação linear}

A programação linear, em decorrência de sua facilidade, de sua versatilidade e do fato de utilizar fundamentos matemáticos simples, como a análise e resolução de sistemas de equações lineares, tem sido o principal método utilizado nos problemas de otimização (Saad et al. 1994). 
Souza et al. (1998), utilizando o software Linear Programming-88 (LP-88) com o propósito de resolver sistemas de equações lineares pelo método simplex revisado, estudaram a otimização da receita líquida de um projeto de irrigação para as culturas de feijão, melancia, milho e tomate por meio de dois cenários. O primeiro cenário previa que a água economizada pela irrigação com déficit poderia ser utilizada para o aumento da área total do projeto e o segundo cenário previa área fixa. As funções e os custos de produção das culturas foram obtidos por Dantas Neto (1994), citado pelos autores, para o projeto de irrigação Senador Nilo Coelho. Os autores concluíram que a maior receita líquida no primeiro cenário foi obtida na irrigação com déficit de $20,0 \%$; porém, a irrigação com déficit de 30,0\% permitia irrigar uma área 14,28\% maior, com uma redução na renda de $0,41 \%$. No segundo cenário, a maior receita líquida foi obtida com irrigação com déficit de 10,0\%.

Saad, et al. (1994), desenvolveram um modelo de programação linear visando a minimização do custo anual de um determinado sistema de irrigação por gotejamento para duas situações: primeiro, considerando o custo da tubulação e o custo com energia, e segundo, considerando apenas o custo da tubulação. Verificou-se que o dimensionamento hidráulico e energético foi o mais eficiente na redução dos custos e que o fator energia somente afetava o dimensionamento do sistema quando a tarifa fosse igual ou superior a US $\$ 0,02522 \mathrm{KW} \mathrm{h}^{-1}$.

Saad \& Mariño (2002), desenvolveram um modelo linear para otimização do dimensionamento de sistemas de irrigação por microaspersão em área retangular, com desnível uniforme no sentido da malha hidráulica e tubulação telescópica. O modelo promove minimização do custo anual da rede hidráulica e do custo anual de bombeamento e maximização da uniformidade de emissão de água previamente estabelecida para a parcela.

\subsubsection{Programação Não Linear}

Holzapfel et al. (1990), desenvolveram um modelo de otimização não linear para dimensionamento e gerenciamento de sistemas de irrigação por gotejamento baseado em funções de produção das culturas em relação à água, tendo como função objetivo a 
maximização do lucro. Neste trabalho, realizado para a cultura da pêra nas condições do Chile, os autores observaram que os custos de aquisição e de operação do sistema são relativamente pequenos quando comparados aos benefícios por ele proporcionados.

De Matos (2000), propôs um sistema de equações não lineares, adaptável ao modelo de programação não linear, visando determinar o dimensionamento ótimo de um sistema de irrigação localizada, sob o enfoque da minimização dos custos para a cultura de goiaba (Psidium guajava L.), variando a evapotranspiração, a declividade do terreno e o tamanho da área a ser irrigada. $\mathrm{O}$ autor verificou que a maior contribuição no custo do equipamento relacionou-se aos emissores, e a evapotranspiração foi o fator que mais afetou o custo do equipamento por unidade de área. Dessa forma, é importante a obtenção de informações meteorológicas regionais confiáveis visando estimativas mais precisas da evapotranspiração e o melhor aproveitamento das precipitações naturais no dimensionamento de sistemas de irrigação.

\subsubsection{Outros Métodos}

Faria et al. (2002), estudando a elevação de pressão na rede hidráulica de um sistema de irrigação por gotejamento provocada pela variação do grau de entupimento dos emissores e a rotação do motor, utilizando planilha eletrônica e recurso de macro do Microsoft Excel $^{\circledR}$, verificou que para a condição de 50,0\% de entupimento e rotação original de projeto do motor diesel, $80,0 \%$ do comprimento da malha hidráulica apresentava pressão superior à classe de pressão da tubulação. Quando a rotação foi aumentada para 2100 RPM, a percentagem da tubulação com pressão superior à classe de pressão aumentou para $98,0 \%$. Os autores verificaram ainda que a redução da rotação do motor mostrou-se eficiente na redução da pressão da malha hidráulica do sistema.

Maia (1994), desenvolveu um software para auxiliar no dimensionamento e no manejo da irrigação localizada. Três métodos de cálculos foram utilizados para o dimensionamento das linhas laterais: método trecho a trecho, método hidráulico e método estatístico. A equação de Darcy-Weisbach foi utilizada para a estimativa da perda de carga, sendo a equação de Hagen-Poiseuille utilizada para calcular o fator de 
atrito em regime laminar e a equação de Blasius para calcular o fator de atrito em regime crítico e turbulento. Para dimensionamento da linha de derivação utilizou-se o método da divisão em trechos e a equação de Veronese-Datei para estimar a perda de carga. O método econômico das tentativas simplificado foi utilizado para o dimensionamento da linha principal, sendo a equação de Hazen-Williams usada para estimar a perda de carga. Para o manejo da irrigação foi sugerido o balanço hídrico com o Tanque classe "A". O autor sugeriu melhorias no programa por meio do uso de um modelo mais elaborado para a estimativa do bulbo molhado, sugeriu ainda a introdução de um banco de dados com diâmetros das tubulações, emissores e moto-bomba, uma ferramenta para gerar gráficos dos perfis de pressão, possibilitar a interação com softwares de CAD para produzir esquemas para montagem, fornecimento de listas com a relação de materiais do projeto e a colocação de um modo de ajuda no programa, com explicações individualizadas de cada módulo.

\subsection{Considerações}

Os problemas que surgem após a implantação de um sistema de irrigação são bem conhecidos, como por exemplo: falta de pressão, entupimento, manejo agrícola influenciando nas operações do sistema, perfurações da tubulação por insetos ou animais, etc. Entretanto, foi difícil encontrar trabalhos publicados que tratam de sistemas de irrigação já implantados e em operação. Encontra-se muitos trabalhos para auxiliar no dimensionamento de sistemas de irrigação, seja localizada, aspersão (convencional ou pivô central) ou sulco, em função do custo de aquisição, do custo operacional, do manejo da irrigação e da uniformidade de aplicação de água, ou de associações entre eles. Portanto, este trabalho segue como um dos pioneiros na avaliação de sistemas de irrigação implantados, permitindo ao produtor ter acesso a uma ferramenta de suporte técnico num eventual problema, seja via revenda de sistemas de irrigação, consultoria ou utilização própria. 


\section{MATERIAL E MÉTODOS}

\subsection{Considerações iniciais sobre o aplicativo PLANLOC 1.0}

Para a criação do aplicativo Planloc 1.0 utilizou-se linguagem Visual Basic Applications ${ }^{\circledR} /$ Microsoft Office $\mathrm{XP}^{\circledR} /$ Excel $^{\circledR}$.

O aplicativo foi construído em 7 planilhas para propiciar um ambiente agradável e menos carregado de informações, de acordo com cada etapa do processo de cálculo, conforme apresentado a seguir: a) planilha inicial; b) planilha de cálculo da lâmina requerida e número de setores, sendo uma para microaspersão e outra para gotejamento; c) planilha para definição do layout e montagem das unidades operacionais; d) cálculo hidráulico; e) seleção do conjunto moto-bomba; f) simulação de funcionamento do projeto; g) banco de dados com informações úteis ao dimensionamento.

\subsubsection{Critérios adotados}

A estrutura da programação não considerou o dimensionamento das tubulações de derivação e lateral, não sendo avaliado, portanto, o efeito da simulação de operação dos setores de irrigação no funcionamento dos emissores, e sim sobre a rede de tubulação principal, secundária e terciária do sistema e nos parâmetros da vazão versus pressão requeridos ao conjunto moto-bomba. Para tal, o aplicativo considera a existência de válvulas reguladoras de pressão ou vazão na entrada de cada parcela, de modo que as simulações no funcionamento do bombeamento não sejam influenciadas pela alteração de vazão dos emissores em função das alterações de pressão do sistema. Assumiu-se 
também a ausência de válvulas de alívio de pressão e de válvula antecipadora de ondas, influenciando sobre as pressões da malha hidráulica e a existência de válvulas ventosas (admissão e expulsão de ar), eliminando qualquer possibilidade de acúmulo e estrangulamento da tubulação.

Assumiu-se que para uma variação de até $20 \%$ na rotação do conjunto motobomba e no diâmetro do rotor da bomba, não há alteração significativa no rendimento da bomba.

A pressão de entrada da parcela não deve ser inferior à mínima determinada, para que os emissores operem de maneira regular e previsível nas simulações.

Para determinação do fator $\mathrm{f}$ da fórmula de Colebrook-White foi utilizado o método numérico Newton-Hapson.

\subsubsection{Análise dos resultados}

A metodologia não prevê utilização de análise estatística na avaliação dos resultados pois ela é determinística.

\subsection{Descrição do aplicativo PLANLOC 1.0}

\subsubsection{Início}

A tela inicial do aplicativo permite ao usuário iniciar os cálculos do projeto ou da simulação, por meio da escolha entre os possíveis métodos de irrigação (microaspersão e gotejamento). A Figura 4 mostra o fluxograma geral do aplicativo de acordo com as etapas a serem executadas. 


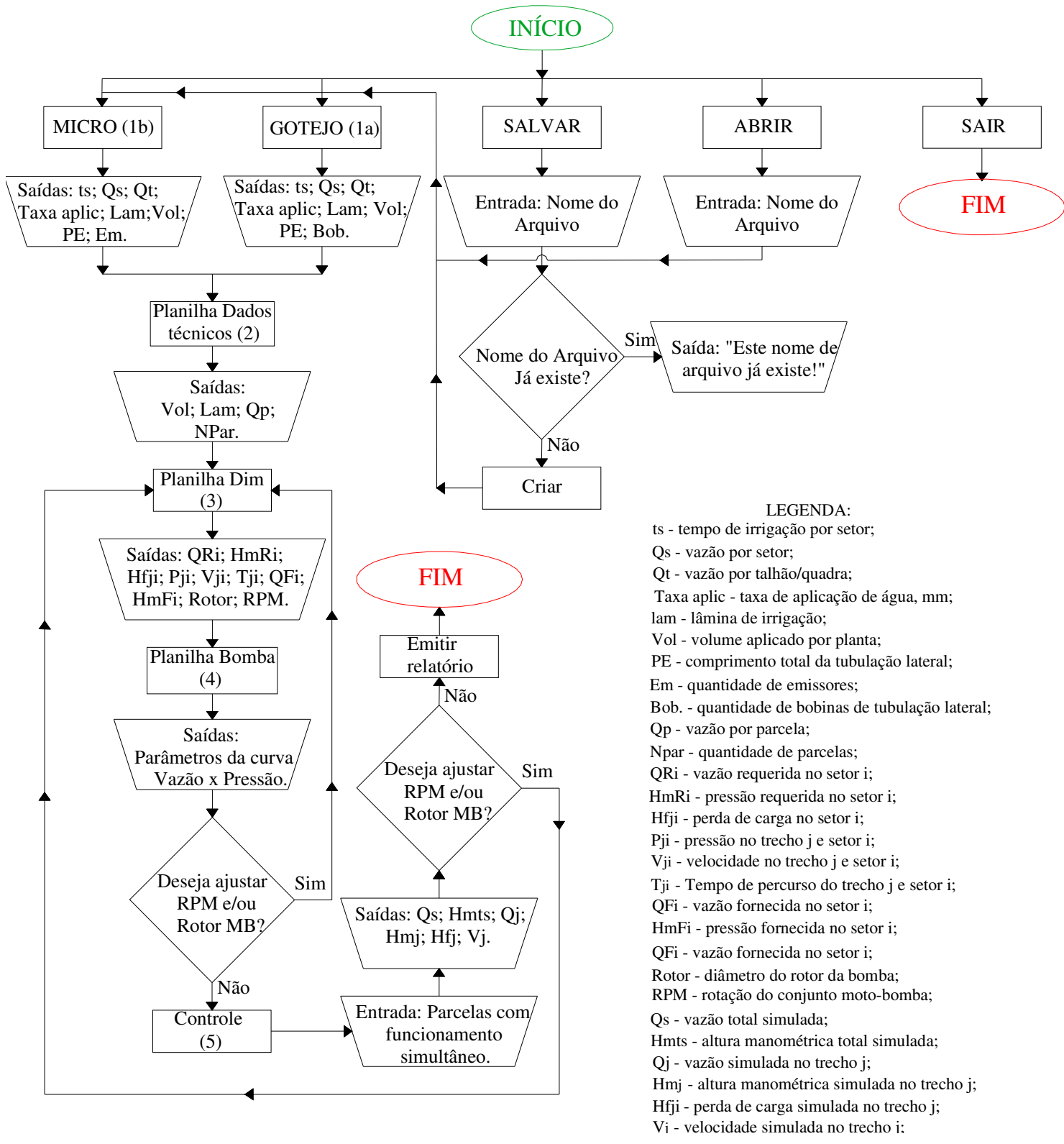

Figura 4 - Fluxograma geral do aplicativo PLANLOC 1.0

\subsubsection{Cálculo da lâmina requerida}

O dimensionamento começa selecionando-se o método de irrigação, microaspersão ou gotejamento na tela inicial. Para cada método existe uma planilha que permite ao usuário determinar qual o emissor e qual o espaçamento entre eles que 
fornece a lâmina desejada em função do espaçamento entre plantas, do número de setores de operação, da eficiência da irrigação e do tempo de funcionamento diário. A Figura 5 mostra o fluxograma para determinação da lâmina requerida.

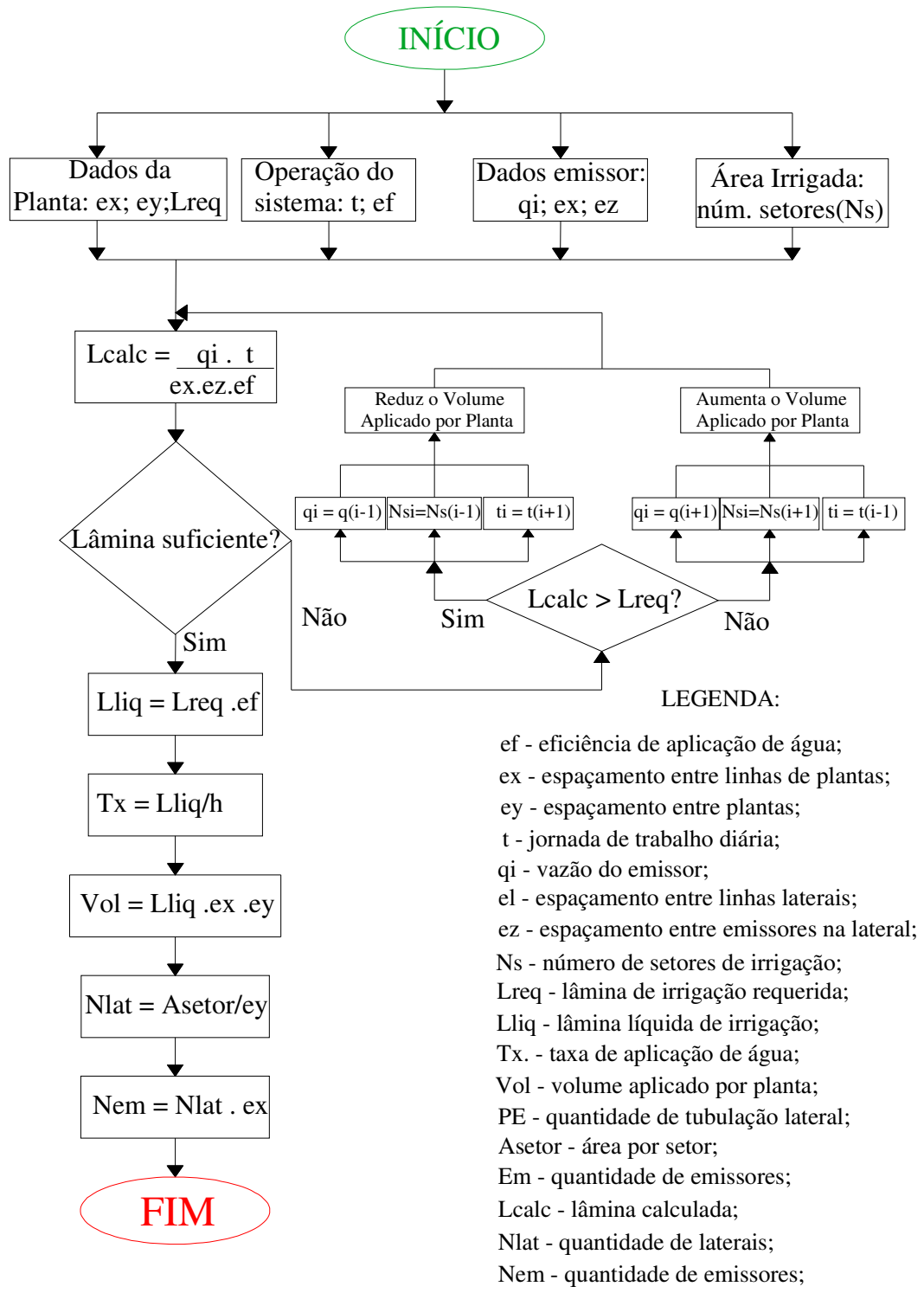

Figura 5 - Fluxograma do cálculo da lâmina requerida

\subsubsection{Definição do layout e setorização}

Após estes cálculos o usuário deve executar, baseado no levantamento planialtimétrico, no alinhamento das quadras e no emissor, a divisão das parcelas e o traçado da tubulação. Não há uma regra para determinar qual a melhor divisão de 
parcelas; portanto, deve se usar o bom senso e a experiência para se obter um bom layout. Com as parcelas divididas e a tubulação traçada, o usuário deve executar a setorização do projeto, ou seja, montar as combinações de parcelas que compõem os setores de irrigação. Normalmente agrupam-se as parcelas em pontos distintos da área com objetivo de diminuir os diâmetros das tubulações e, conseqüentemente, o custo do projeto. Esta estratégia, entretanto, traz o risco de irrigar simultaneamente variedades distintas, com diferentes necessidades e em diferentes estágios fisiológicos.

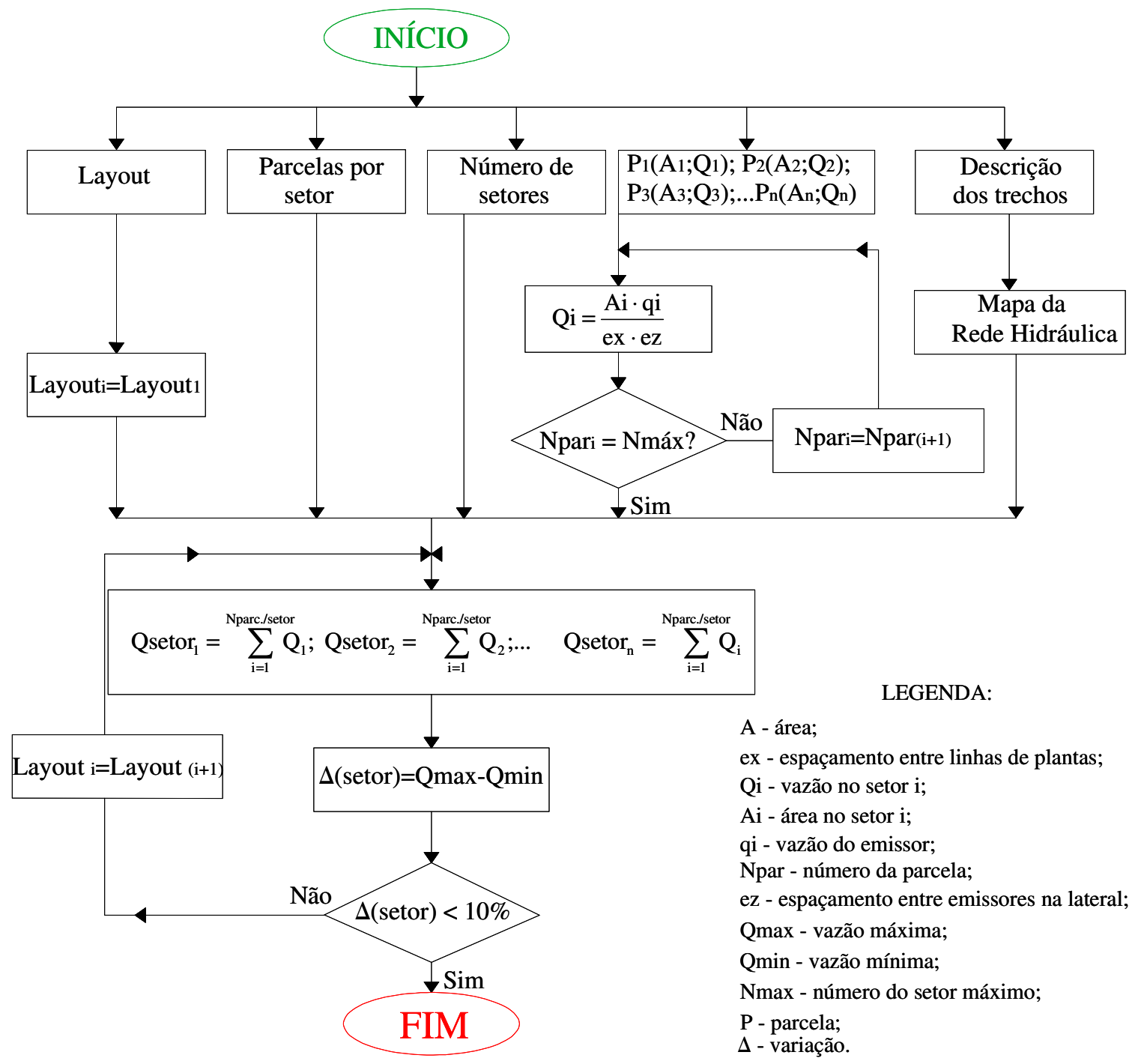

Figura 6 - Fluxograma para definição do layout e setorização 


\subsubsection{Cálculo hidráulico}

\subsubsection{Entrada de dados}

Após a montagem dos setores deve-se numerar os "trechos" da tubulação sempre a partir da moto-bomba conforme descrito por Souza et al. (2000): a moto-bomba possui número zero; o primeiro trecho conectado à moto-bomba recebe número um (1); a numeração nos trechos deve ser contínua; inicialmente numerar a maior sequiência de trechos com maior número de nós; a numeração de um trecho à jusante deve ser sempre maior que a numeração do trecho à montante; os trechos que derivam de um mesmo nó devem seguir a regra anterior; os números não podem ser repetidos; a planilha é limitada em 27 trechos.

Define-se como "trecho" da tubulação o intervalo entre dois nós consecutivos. Por sua vez, define-se como "nó", um ponto de bifurcação, uma válvula hidráulica, um ponto de alteração de diâmetro ou classe de pressão da tubulação e qualquer outro ponto da tubulação que se julgue necessário.

Ao terminar esta tarefa o usuário acessa a planilha "Dados", onde irá alimentar o aplicativo com os dados do projeto. Primeiramente deve-se preencher o número de parcelas em cada setor e pressionar o botão "SETORIZAÇÃO", para que seja montado o quadro de entradas de dados (Figura 7).

Os dados de entrada de cada parcela são: número do trecho imediatamente anterior à entrada da válvula, área irrigada, espaçamento entre plantas e emissores e pressão mínima necessária antes da entrada da válvula. Preenchido estes dados pressiona-se o botão "CALCULAR" para que o aplicativo forneça o quadro de funcionamento dos setores de irrigação e os dados de lâmina aplicada (equação 23), volume de água aplicado por planta (equação 24) e vazão da parcela (equação 25), como pode ser visualizado na Figura 7, em destaque. Caso tenha havido algum erro, basta pressionar o botão "LIMPAR" para eliminar todos os dados digitados e começar novamente. 


$$
\begin{aligned}
& \text { Lliq }=\frac{\mathrm{q}_{\mathrm{i}} \times \mathrm{ts}}{\text { Ez } \times \mathrm{el} \times \mathrm{ef}} \\
& \text { Vol }=\mathrm{q}_{\mathrm{i}} \times \mathrm{ts} \\
& \mathrm{Qp}=\frac{\mathrm{Ap} \times \mathrm{q}_{\mathrm{i}} \times \mathrm{ts}}{\mathrm{ez} \times \mathrm{el}}
\end{aligned}
$$

sendo:

$\mathrm{L}_{\mathrm{liq}}$ - lâmina líquida aplicada (mm dia $\left.{ }^{-1}\right)$;

$\mathrm{q}_{\mathrm{i}}$ - vazão por emissor $\left(\mathrm{l} \mathrm{h}^{-1}\right)$;

ts - horas de funcionamento por setor;

ez - Espaçamento entre emissores na lateral (m);

el - Espaçamento entre linhas laterais (m);

ef - eficiência de aplicação (decimal)

Vol - Volume aplicado por planta $\left(1 \mathrm{pl}^{-1} \mathrm{dia}\right)$;

Qp - Vazão por parcela $\left(\mathrm{m}^{3} \mathrm{~h}^{-1}\right)$;

Ap - Área por parcela $\left(\mathrm{m}^{2}\right)$; 


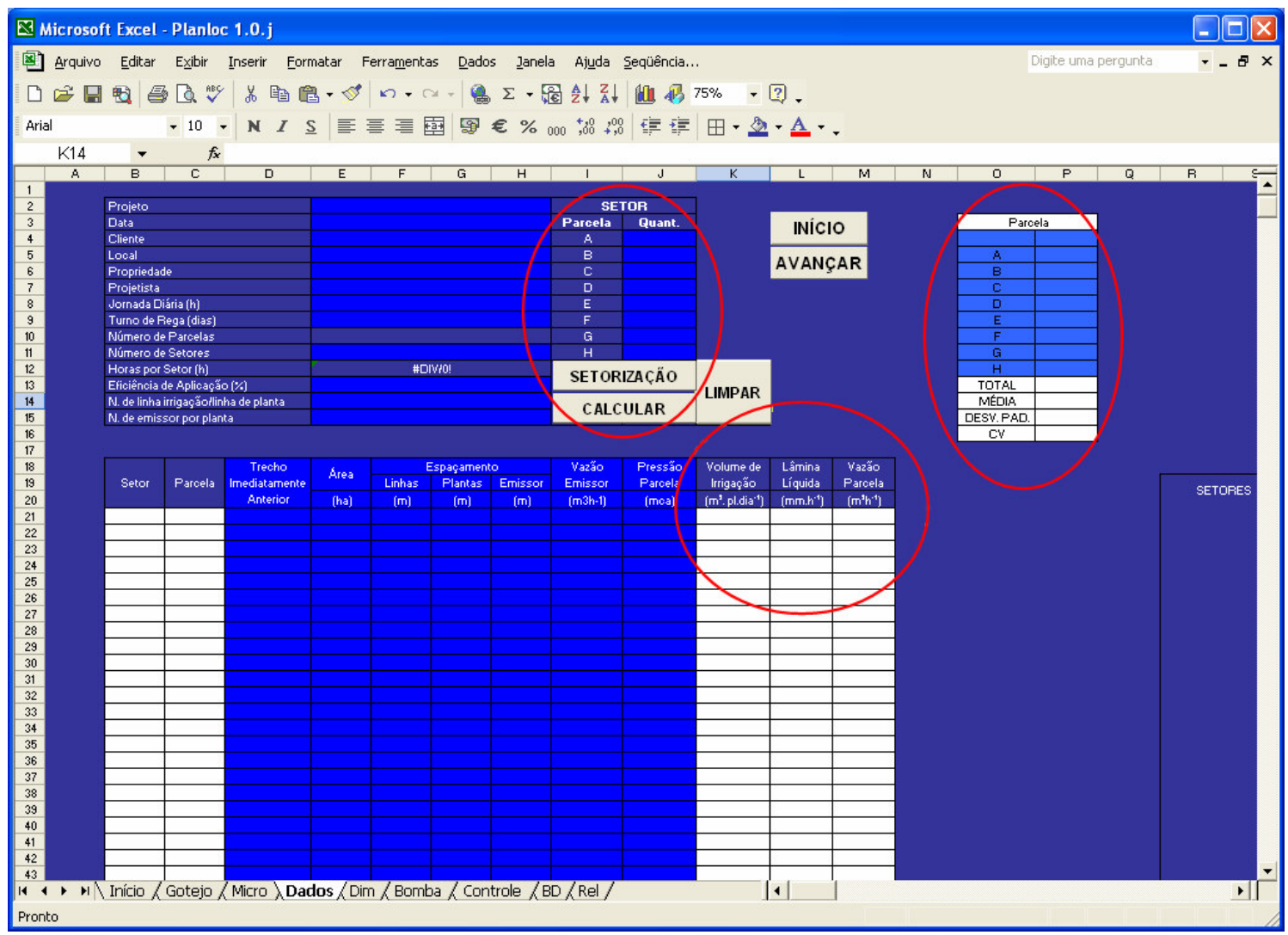

Figura 7 - Células de entrada para montagem dos setores de irrigação

\subsubsection{Cálculo hidráulico da vazão e pressão requerido pelo sistema}

Na etapa subseqüente acessa-se a planilha "Dim", onde são realizados os cálculos hidráulicos do projeto no sentido do ponto crítico ao ponto de bombeamento. Para realizar o cálculo da perda de carga ao longo das tubulações o aplicativo permite escolher entre a fórmula de Hazen-Williams (equação 10), muito utilizada pelos projetistas das principais empresas de fornecimento de equipamentos de irrigação e a fórmula de Darcy-Weisbach (equação 3). Em relação às perdas de carga localizadas no sistema, o aplicativo não as calcula, portanto deve-se determiná-las manualmente e digitá-las nas células específicas "Moto-bomba" e "Filtragem" e informar o trecho imediatamente anterior. Normalmente as perdas de carga localizadas nas conexões da malha hidráulica do sistema são computadas junto com as perdas do bombeamento. A filtragem possui uma célula separada para digitação do valor da perda de carga, pois 
pode representar um valor alto e precisa ter o seu posicionamento na malha hidráulica especificado.

Nesta planilha deve-se entrar com os dados da tubulação (diâmetro interno e externo e classe de pressão), da topografia (diferença de nível entre os nós) e de cada "trecho" (comprimento). Para que o aplicativo possa interpretar a forma de distribuição de água do projeto é necessário digitar na coluna denominada "Anterior" o número do trecho imediatamente anterior ao trecho atual (que está sendo preenchido). Com os dados digitados, pressiona-se o botão "REQUERIDO" para o aplicativo calcular as perdas de carga e fornecer a pressão final de cada trecho e determinar a vazão e altura manométrica total necessária ao conjunto moto-bomba. Com os dados de altura manométrica e vazão, seleciona-se entre os diversos fabricantes um modelo de bomba que atenda às necessidades do projeto.

\subsubsection{Seleção do conjunto moto-bomba}

Após a seleção da bomba, acessa-se a planilha "Bomba", onde será realizado o ajuste do diâmetro do rotor da bomba e da rotação do motor. Por meio da curva característica da bomba preenche-se os dados de vazão, altura manométrica e potência absorvida para o diâmetro de rotor original (maior diâmetro) e o aplicativo calcula a eficiência da bomba (equação 18) e o torque requerido do motor (equação 19).

Por meio das equações $11,12,13,19,20$ e 21 , o aplicativo calcula os novos dados de, pressão, potência, e torque, para qualquer diâmetro de rotor e qualquer rotação do motor. Isto é importante para ajustar a combinação, entre eles, que gera o melhor rendimento ao conjunto moto-bomba, principalmente no caso de motores diesel, que possuem uma relação entre rotação e torque que propicia o menor consumo específico. A planilha "Bomba" permite ainda realizar simulações de associações de no máximo duas bombas em paralelo ou em série, apenas para modelos de bombas iguais. Estas associações são importantes para dimensionar conjuntos moto-bomba com menores potências, para atender às exigências das companhias de fornecimento de energia 
elétrica, para, em caso de quebra de um conjunto, o outro poder, em algumas situações, operar uma parte da área irrigada e para trabalhar com modelos de bomba com apenas um estágio, mais baratos em relação aos modelos multi-estágios. A Figura 8 mostra o fluxograma do processo de cálculo hidráulico e seleção do conjunto moto-bomba.

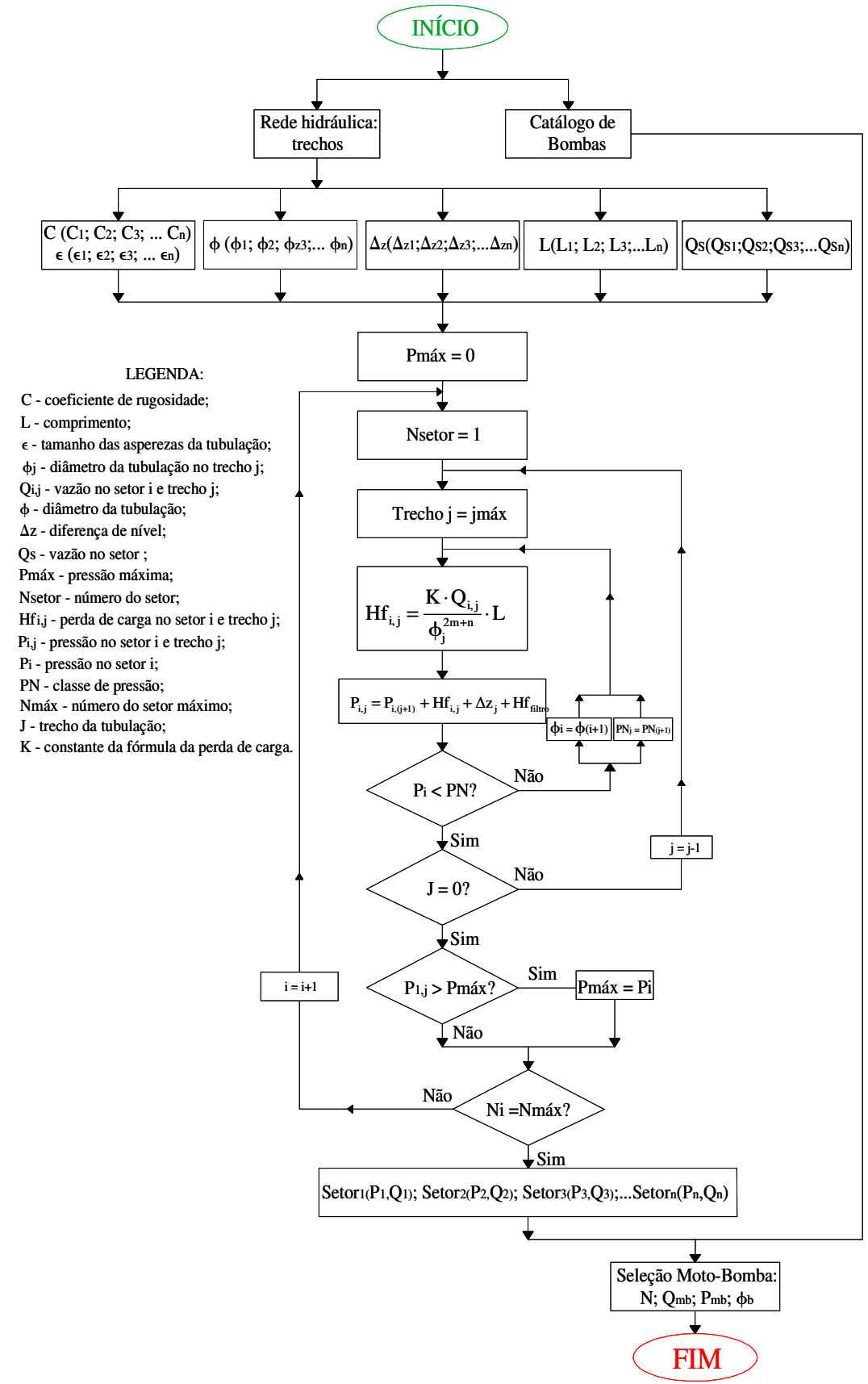

Figura 8 - Fluxograma para determinação do ponto de trabalho da moto-bomba 


\subsubsection{Simulação de funcionamento do projeto}

\subsubsection{Simulação do conjunto moto-bomba}

A simulação do funcionamento dos setores de irrigação foi realizada a partir da equação gerada pela regressão polinomial (cúbica ou quadrática) dos pares de dados de vazão versus pressão da bomba, ajustada graficamente pelo Microsoft Excel ${ }^{\circledR}$. Quando a equação utilizada for quadrática deve-se digitar o valor zero na célula correspondente ao parâmetro "A" na planilha "Dim".

$$
y=a x^{3}+b x^{2}+c x+d
$$

Sendo:

$y$ - pressão, mca;

a, b, c e d - parâmetros da curva polinomial quadrática;

$x$ - vazão, $\mathrm{m}^{3} \mathrm{~h}^{-1}$.

Como a equação da curva da bomba gerada pela regressão linear está em função da vazão, o aplicativo encontra a pressão de saída da bomba a partir da vazão calculada para cada situação simulada e, em casos de sistemas diesel ou, na possibilidade, cada dia mais viável, da utilização de inversores de freqüência para motores elétricos, permite variar o diâmetro do rotor (equações 14, 15 e 16), a rotação do motor (equações 17, 18 e 19), ou ambos (equações 11, 12 e 13), para ajustar os valores de pressão aos requeridos pelo projeto.

\subsubsection{Cálculo hidráulico das pressões nos trechos}

Nesta etapa o aplicativo calcula as pressões nos trechos da tubulação, a partir da moto-bomba, no sentido do caminhamento da água, permitindo analisar as pressões do sistema com maior realidade, pois considera as pressões estáticas nos trechos que não 
possuem vazão. Caso algum trecho apresente pressão superior à classe de pressão da tubulação ou inferior à desejada, o usuário pode corrigir os diâmetros e classes de pressões utilizadas e retornar ao passo "REQUERIDO".

O usuário pode, ainda, ajustar a vazão ou a pressão do bombeamento, em função dos resultados obtidos, alterando o diâmetro do rotor da bomba: botão "AJUSTAR ROTOR" (equações 11, 12 e 13); ou alterando a rotação da bomba: botão "AJUSTAR ROTAÇÃO" (equações 14, 15 e 16). Neste caso não há necessidade de ajustar a curva na planilha "Bomba".

\subsubsection{Simulações}

Para executar as simulações o usuário deve pressionar o botão "CONTROLE". Nesta planilha o usuário escolhe quais parcelas deseja operar simultaneamente por meio da digitação da letra "xis", em maiúsculo, no quadro de funcionamento criado pelo aplicativo. Para verificar o resultado da simulação deve-se pressionar o botão "CALCULAR". A Figura 6 apresenta o fluxograma do processo de simulação de funcionamento do projeto de irrigação. 


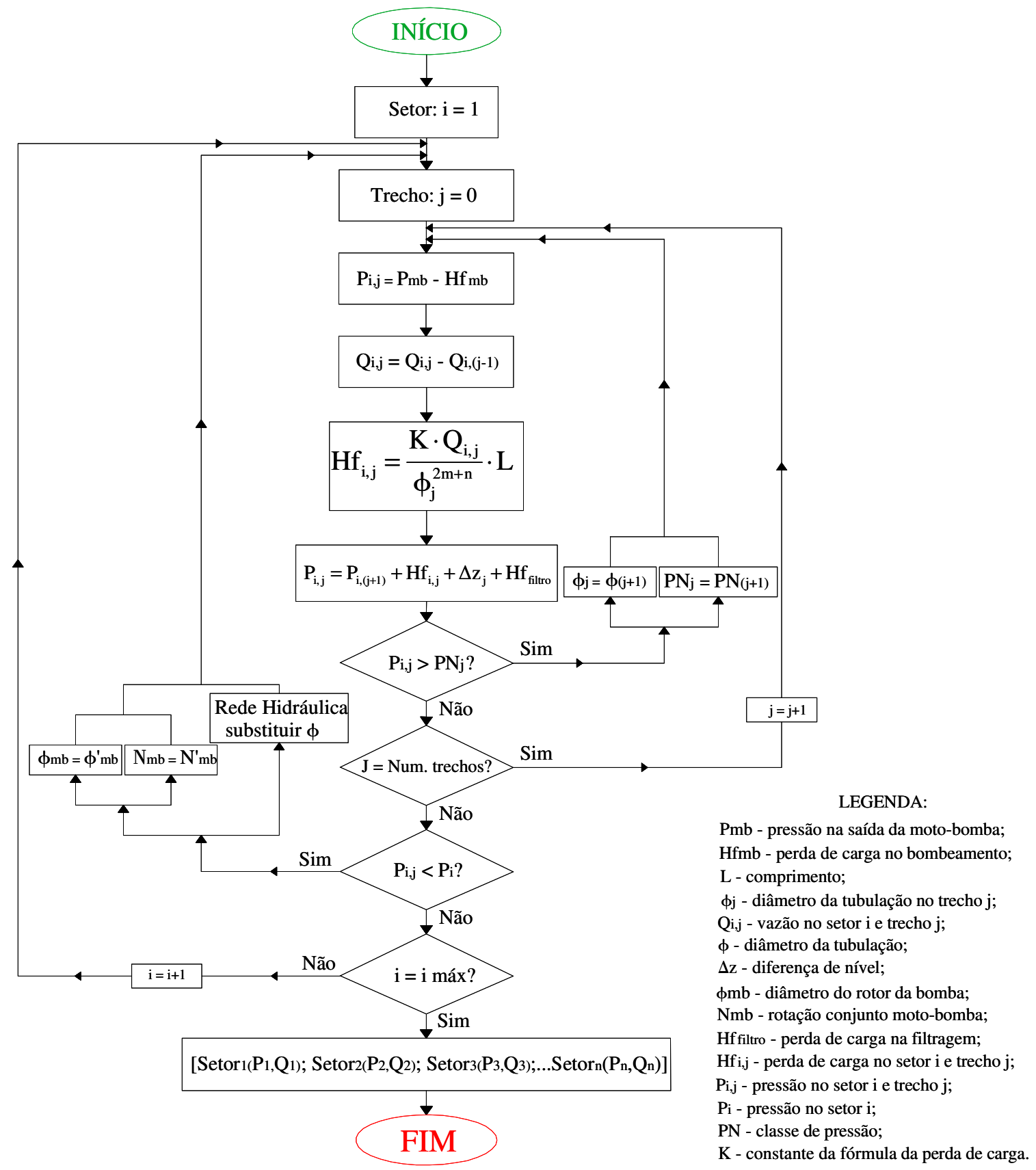

Figura 9 - Fluxograma para simulação da malha hidráulica em função da alteração dos pontos de trabalho do conjunto moto-bomba 


\subsection{Caracterização da área para aplicação do modelo}

\subsubsection{Localização e área}

O sistema de irrigação (hipotético) utilizado para este trabalho está instalado em uma área de 152,1 ha de superfície total e 144,0 ha de superfície útil de citros, com formato retangular (1.632 metros de largura por 932 metros de comprimento) e 42,0 metros de diferença de nível, considerando da cota do nível da água no ponto de captação ao ponto mais alto na área. Supõe-se que a área esteja localizada no município de Boa Esperança do Sul, região central do Estado de São Paulo entre as coordenadas latitude $21^{\circ} 59^{\prime} \mathrm{S}$ e longitude $48^{\circ} 24^{\prime}$ 'W a 500 metros de altitude.

\subsubsection{Caracterização do pomar}

Supôs-se que a área tenha sido implantada em 1993 com a cultura de citros em porta-enxerto de tangerina Cleópatra (Citrus reticulata, Blanco) e Limão Cravo (Citrus Limonia, Osbeck), divididos nas variedades de laranja doce (Citrus sinensis, (L) Osbeck) conforme apresentado na Tabela 5.

Tabela 5. Área, espaçamento e número de plantas correspondentes às variedades utilizadas no projeto

\begin{tabular}{|c|c|c|c|c|c|c|}
\hline \multirow{2}{*}{ Talhão } & \multirow{2}{*}{ Variedade } & \multirow{2}{*}{ Porta-enxerto } & \multirow{2}{*}{$\begin{array}{l}\text { Área } \\
\text { (ha) }\end{array}$} & \multicolumn{2}{|c|}{ Espaçamento (m) } & \multirow{2}{*}{$\mathrm{N}^{\mathrm{o}}$ Plantas } \\
\hline & & & & Linhas & Plantas & \\
\hline 1 & Pêra Rio & Cleópatra & 36,0 & 6,5 & 3,5 & $15.824,0$ \\
\hline 2 & Natal & Cleópatra & 36,0 & 6,5 & 3,5 & $15.824,0$ \\
\hline 3 & Valência & Limão Cravo & 36,0 & 6,5 & 3,5 & $15.824,0$ \\
\hline 4 & Hamlin & Cleópatra & 36,0 & 6,5 & 3,5 & $15.824,0$ \\
\hline Total & & & 144,0 & & & $63.296,0$ \\
\hline
\end{tabular}




\subsection{Caracterização do projeto de irrigação para aplicação do modelo}

\subsubsection{Projeto executivo}

A divisão das parcelas, o traçado da tubulação, o posicionamento das válvulas hidráulicas e outras características do projeto hidráulico podem ser visualizados na planta do projeto executivo (CD em Anexo).

\subsubsection{Dados técnicos do projeto de irrigação}

Os dados técnicos do projeto de irrigação estão identificados na Tabela 6.

Tabela 6. Dados técnicos do projeto de irrigação

\begin{tabular}{lc}
\hline Descrição & Valor \\
\hline Sistema & Microaspersão \\
Modelo do emissor & NaanDan 2001 \\
Autocompensante & Sim \\
Vazão do emissor & $28,00{\mathrm{~L} . \mathrm{h}^{-1}}^{-1}$ \\
Espaçamento entre emissores & Idem ao plantio \\
Número de emissores por planta & 1,00 \\
Lâmina bruta aplicada & $4,21 \mathrm{~mm}$ \\
Lâmina líquida aplicada & $3,99 \mathrm{~mm}$ \\
Volume aplicado por planta por dia & $95,76 \mathrm{~L}$ \\
Eficiência da irrigação & $95,00 \%$ \\
Fator de cobertura adotado & $75,00 \%$ \\
Número de unidades operacionais (setores) & 6,00 \\
Número de parcelas de operação & 48,00 \\
Número de parcelas em operação simultânea & 8,00 \\
Área por parcela & $3,00 \mathrm{ha}$ \\
Tempo de funcionamento diário & $20,52 \mathrm{~h}$. \\
Tempo de funcionamento por setor de Operação & $3,42 \mathrm{~h}$. \\
\hline
\end{tabular}




\subsubsection{Quadro de funcionamento}

O projeto de irrigação opera conforme a combinação de parcelas mostradas na Tabela 7 e na Figura 10, ou seja, as parcelas com o mesmo número e mesma cor (setor) operam simultaneamente.

Tabela 7. Quadro de funcionamento dos blocos de irrigação

\begin{tabular}{ccccccc}
\hline \multirow{2}{*}{ Parcela } & \multicolumn{5}{c}{ Setor - Vazão $\left(\mathrm{m}^{3} \cdot \mathrm{h}^{-1}\right)$} \\
& 1 & 2 & 3 & 4 & 5 & 6 \\
\hline A & 36,92 & 36,92 & 36,92 & 36,92 & 36,92 & 36,92 \\
B & 36,92 & 36,92 & 36,92 & 36,92 & 36,92 & 36,92 \\
C & 36,92 & 36,92 & 36,92 & 36,92 & 36,92 & 36,92 \\
D & 36,92 & 36,92 & 36,92 & 36,92 & 36,92 & 36,92 \\
E & 36,92 & 36,92 & 36,92 & 36,92 & 36,92 & 36,92 \\
F & 36,92 & 36,92 & 36,92 & 36,92 & 36,92 & 36,92 \\
G & 36,92 & 36,92 & 36,92 & 36,92 & 36,92 & 36,92 \\
H & 36,92 & 36,92 & 36,92 & 36,92 & 36,92 & 36,92 \\
Total & 295,38 & 295,38 & 295,38 & 295,38 & 295,38 & 295,38 \\
\hline
\end{tabular}

\begin{tabular}{|c|c|c|c|c|c|c|c|}
\hline $1 \mathrm{~A}$ & $2 \mathrm{~A}$ & $1 \mathrm{~B}$ & $2 \mathrm{~B}$ & $1 \mathrm{C}$ & $2 \mathrm{C}$ & $1 \mathrm{D}$ & $2 \mathrm{D}$ \\
\hline $3 \mathrm{~A}$ & $4 \mathrm{~A}$ & $3 \mathrm{~B}$ & $4 \mathrm{~B}$ & $3 \mathrm{C}$ & $4 \mathrm{C}$ & $3 \mathrm{D}$ & $4 \mathrm{D}$ \\
\hline $5 \mathrm{~A}$ & $6 \mathrm{~A}$ & $5 \mathrm{~B}$ & $6 \mathrm{~B}$ & $5 \mathrm{C}$ & $6 \mathrm{C}$ & $5 \mathrm{D}$ & $6 \mathrm{D}$ \\
\hline $1 \mathrm{E}$ & $2 \mathrm{E}$ & $1 \mathrm{~F}$ & $2 \mathrm{~F}$ & $1 \mathrm{G}$ & $2 \mathrm{G}$ & $1 \mathrm{H}$ & $2 \mathrm{H}$ \\
\hline $3 \mathrm{E}$ & $4 \mathrm{E}$ & $3 \mathrm{~F}$ & $4 \mathrm{~F}$ & $3 \mathrm{G}$ & $4 \mathrm{G}$ & $3 \mathrm{H}$ & $4 \mathrm{H}$ \\
\hline $5 \mathrm{E}$ & $6 \mathrm{E}$ & $5 \mathrm{~F}$ & $6 \mathrm{~F}$ & $5 \mathrm{G}$ & $6 \mathrm{G}$ & $5 \mathrm{H}$ & $6 \mathrm{H}$ \\
\hline
\end{tabular}

Figura 10 - Visão esquemática da distribuição dos setores de funcionamento na área 


\section{RESULTADOS E DISCUSSÃO}

\subsection{Caracterização do Aplicativo}

Utilizando o Software Visual Basic Applications $\left(\mathrm{VBA}^{\circledR}\right)$ na plataforma do Microsoft Excel ${ }^{\circledR}$ criou-se o aplicativo PLANLOC 1.0. O aplicativo parte de uma tela inicial (Figura 11), onde se têm as informações dos autores e as opções de salvar um arquivo novo, abrir um arquivo existente, sair do aplicativo e escolher entre os métodos de irrigação gotejamento ou microaspersão.

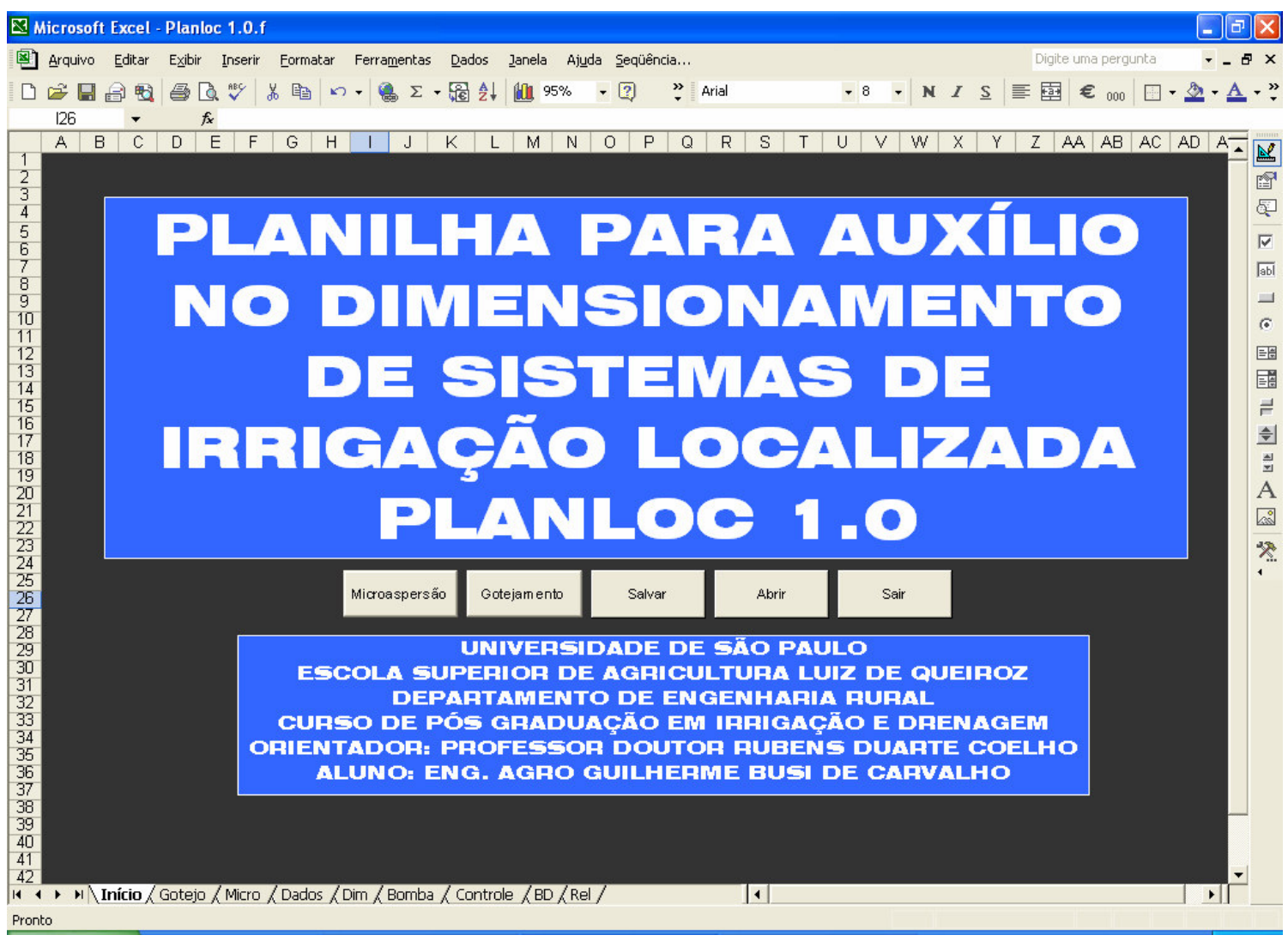

Figura 11 - Tela inicial do aplicativo PLANLOC 1.0 
Para o dimensionamento do sistema de irrigação localizada o usuário deverá seguir os seguintes passos: a) definição do número de setores de irrigação; b) definição do layout da irrigação; c) definição do traçado da tubulação; d) dimensionamento da malha hidráulica; e) seleção do conjunto moto-bomba; f) ajuste da malha hidráulica ao conjunto moto-bomba; g) simulação de operação.

\subsubsection{Definição do número de setores de irrigação}

Em função da lâmina de irrigação determinada para o projeto, do espaçamento da cultura e da jornada de trabalho diária da propriedade, seleciona-se o emissor a ser utilizado no projeto e define-se o número de setores de irrigação. O aplicativo permite que esses cálculos sejam realizados facilmente para diversos tipos de cultura, com diferentes espaçamentos entre plantas.

O aplicativo parte de uma lâmina de irrigação determinada, ao invés de realizar os cálculos em função dos parâmetros físico-hídricos do solo; este procedimento visa permitir ao usuário escolher a lâmina que melhor se ajusta às variações da área e do projeto.

As entradas de dados para determinação do número de setores são realizadas nas planilhas "Micro" e "Gotejo" acessadas a partir da página inicial clicando-se nos botões com os referidos tipos de emissores. O usuário deve preencher os dados nas células com coloração azul claro. Caso a área apresente um número maior ou menor de quadras ou talhões que os especificados na planilha, basta clicar nos botões "INSERIR LINHA" para inserir uma linha de preenchimento de dados ou "RETIRAR LINHA" para eliminála. A Figura 12 e a Figura 13 mostram as entradas de dados para microaspersão e gotejamento. 


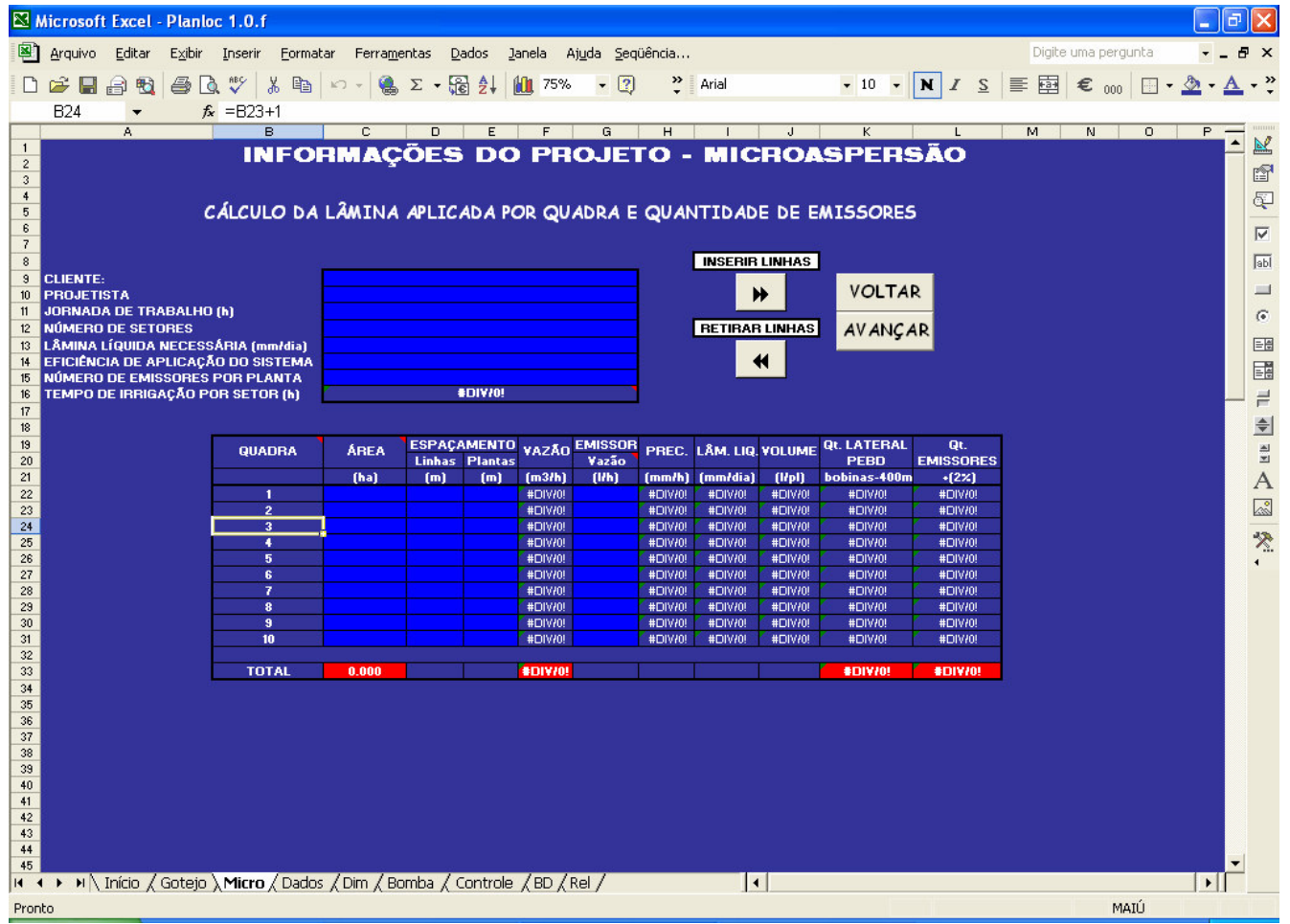

Figura 12 - Planilha para dimensionamento do número de setores para microaspersão

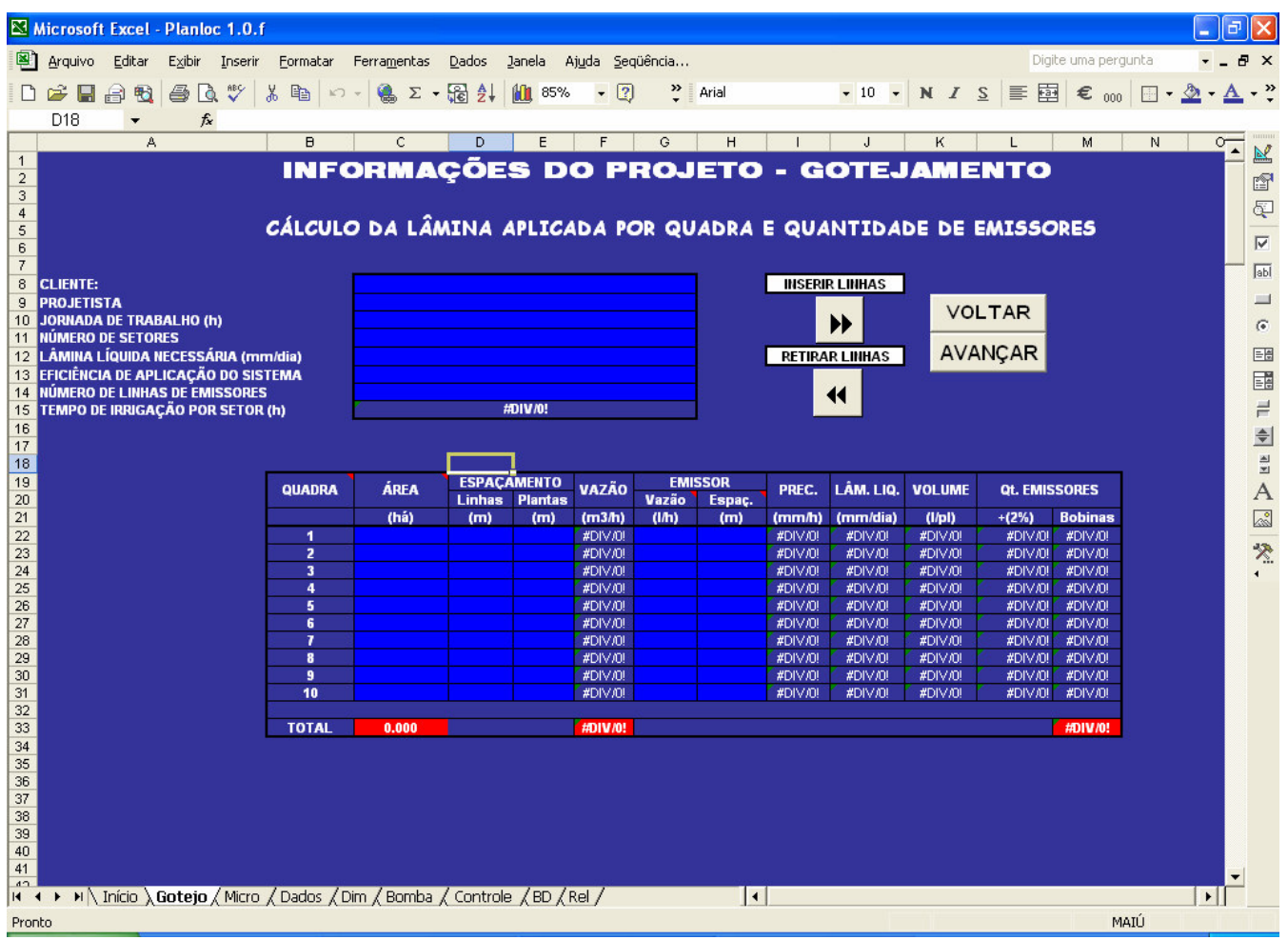

Figura 13 - Planilha para dimensionamento do número de setores para gotejamento 
Ao preencher os dados na planilha, para a seleção do emissor e do número de setores de funcionamento, são calculadas a precipitação $\left(\mathrm{mm} \mathrm{h}^{-1}\right)$, a vazão do talhão ou quadra $\left(\mathrm{m}^{3} \mathrm{~h}^{-1}\right)$, vazão média por setor $\left(\mathrm{m}^{3} \mathrm{~h}^{-1}\right)$, a lâmina diária $(\mathrm{mm}) \mathrm{e}$ a quantidade de emissores (m, para gotejamento e unidades, para microaspersão), no caso da planilha de microaspersão a quantidade, em bobinas, da tubulação lateral de PEBDL, também é determinada.

Para avançar no aplicativo, basta clicar no botão "AVANÇAR".

\subsubsection{Definição do layout da irrigação}

As parcelas de irrigação devem ser divididas com base no levantamento planialtimétrico, nas características do emissor selecionado, que limita o comprimento máximo da linha lateral, na topografia do terreno, na cultura e no solo. A divisão deve propiciar, na medida do possível, uma vazão uniforme entre os setores de irrigação e, principalmente, com um bom coeficiente de uniformidade de distribuição de água. A Figura 14 mostra a tela da planilha "Dados" do aplicativo que auxilia na definição do layout do projeto. Para utilizá-la deve-se inserir a quantidade de parcelas em cada setor de irrigação, por exemplo, no projeto utilizado neste trabalho são 8 parcelas para cada um dos seis setores de irrigação, portanto, temos 6 parcelas com a letra "A", 6 parcelas com a letra "B", e assim por diante até a letra "H", ou seja, 8 letras vezes 6 setores totalizam as 48 parcelas do projeto. Os números de parcelas por setor não precisam ser uniformes. Para seguir no aplicativo pressiona-se o botão "SETORIZAÇÃO" para que seja montado, com as parcelas já especificadas, o quadro de entrada dos dados que serão utilizados nesta etapa de definição do layout: área (ha); espaçamento entre linhas, plantas e emissores (m) e vazão do emissor $\left(\mathrm{h} \mathrm{h}^{-1}\right)$. Após inserir os dados deve-se pressionar o botão "CALCULAR" para o aplicativo calcular a vazão de cada parcela $\left(\mathrm{m}^{3}\right.$ $\left.\mathrm{h}^{-1}\right)$, a lâmina líquida (mm) e o volume aplicado por planta $\left(\mathrm{pl}^{-1}\right.$ dia) e montar o quadro de funcionamento do projeto, onde se pode realizar o comparativo entre as vazões de 
cada setor de irrigação. Normalmente adota-se um coeficiente de tolerância de $10 \%$ de variação na vazão entre os setores.

\subsubsection{Definição do traçado da tubulação}

O traçado da tubulação deve ser realizado de acordo com a divisão das áreas (parcelas) no campo e com as características dos emissores utilizados (comprimento máximo de linha lateral), respeitando o alinhamento de plantio para facilitar a montagem do sistema. As tubulações de derivação devem ser traçadas perpendiculares ao sentido de plantio e/ou, na medida do possível, às curvas de nível do terreno no sentido decrescente, permitindo utilizar as linhas laterais em nível e obter um bom equilíbrio hidráulico. Com o traçado realizado o usuário deve executar o cálculo "interno" das parcelas, ou seja, o dimensionamento das linhas laterais e das linhas de derivação, pois a pressão necessária na entrada de cada parcela é um dado importante para o aplicativo e deve ser digitado da planilha "Dados" (Figura 14, em destaque). Após esta etapa numera-se os trechos da tubulação e digita-se na planilha o número do trecho imediatamente anterior à entrada da parcela. Por exemplo, no projeto utilizado o trecho imediatamente anterior à parcela $1 \mathrm{~A}$ é o trecho 27 e a pressão necessária na entrada da parcela é 31,5 mca. 


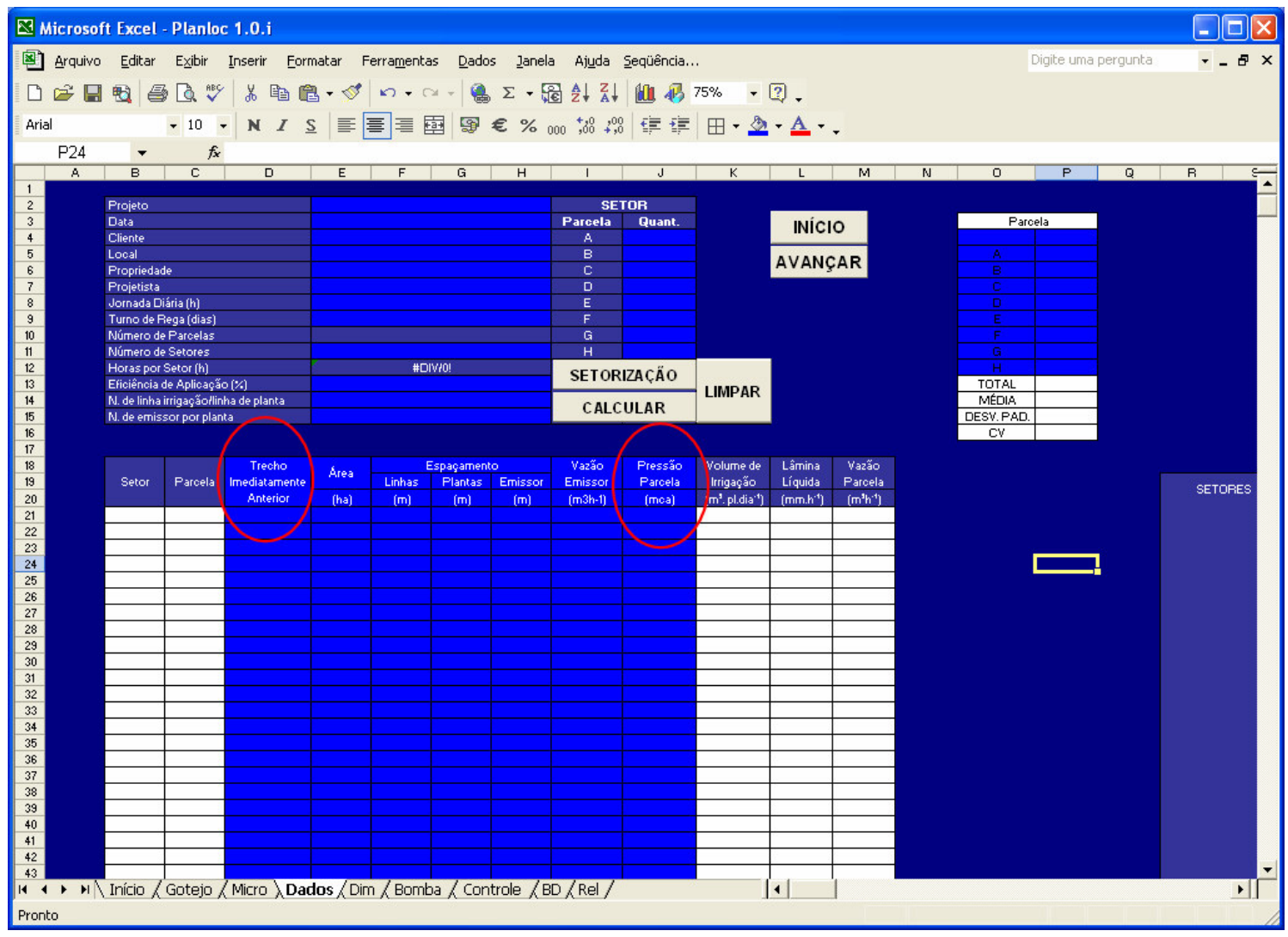

Figura 14 - Tela da planilha "Dados"

\subsubsection{Dimensionamento da malha hidráulica}

Primeiramente, digita-se o número de trechos do projeto e pressiona-se o botão "INSERIR", para o aplicativo preencher a seqüência no quadro de entrada de dados na planilha "Dim". Posteriormente, por meio da entrada dos dados dos componentes do sistema (tubulação e peças especiais) e da altimetria da área, calcula-se as perdas de carga do sistema e dimensiona-se o diâmetro e a classe de pressão da tubulação do ponto crítico (maior demanda de energia do sistema) ao ponto de bombeamento. Os dados de entrada são: trecho anterior; diâmetro nominal $(\mathrm{mm})$; classe de pressão $(\mathrm{PN})$ e diâmetro interno $(\mathrm{mm})$ da tubulação, comprimento do trecho $(\mathrm{m})$, diferença de nível entre o início e o final do trecho $(\mathrm{m})$ e coeficiente de atrito ( $\mathrm{C}$, adimensional), para a fórmula de Hazen-Williams e tamanho das asperezas da tubulação $(\varepsilon, \mathrm{mm})$, para a fórmula de Darcy-Weisbach. Com os dados preenchidos pressiona-se o botão "REQUERIDO” para o aplicativo calcular as perdas de carga e fornecer os pontos de trabalho do conjunto 
moto-bomba para cada setor do projeto de irrigação. A Figura 15 mostra a tela inicial da planilha "Dim".

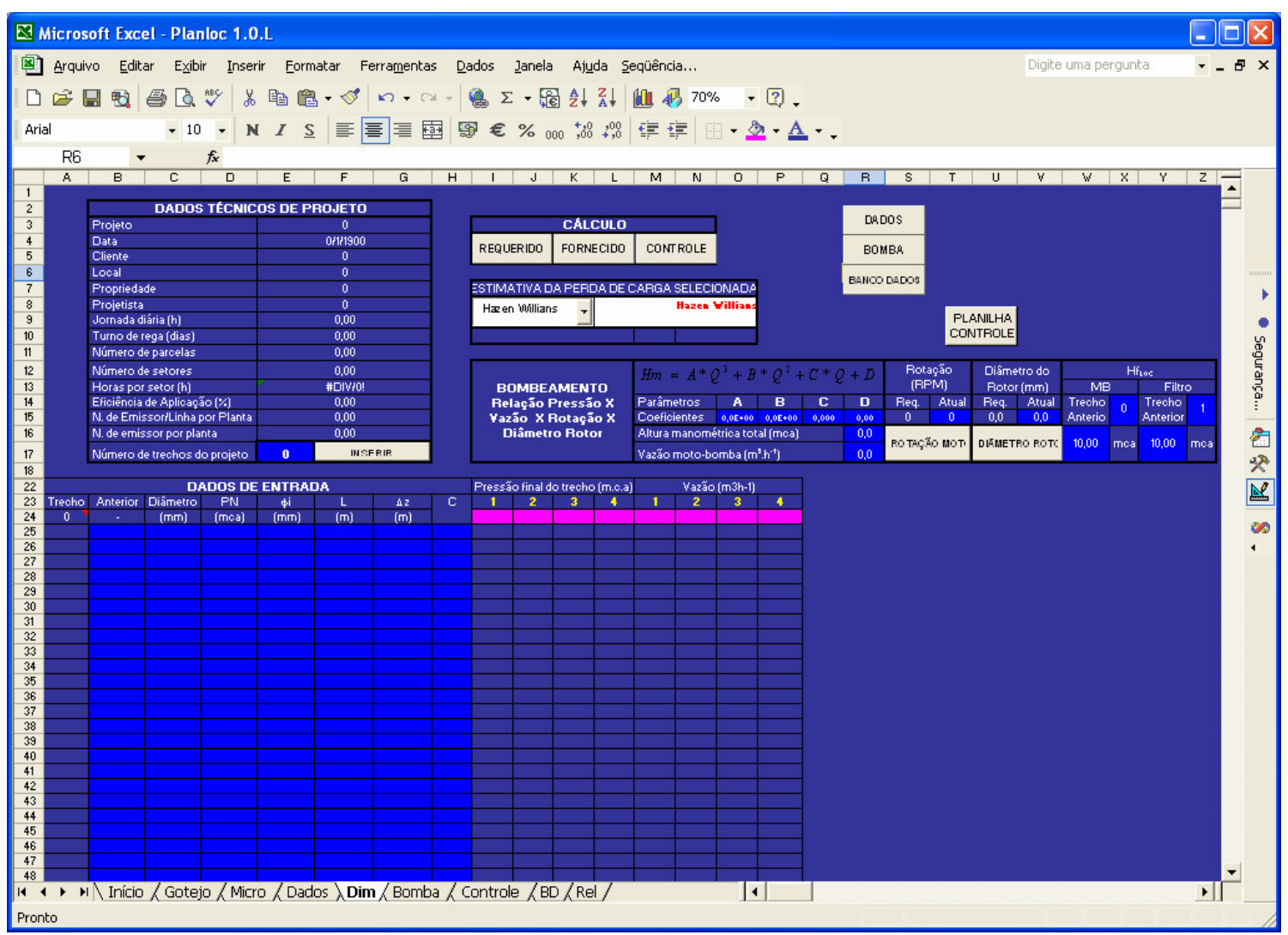

Figura 15 - Tela da planilha "Dim"

\subsubsection{Seleção do conjunto moto-bomba}

Por meio dos dados de vazão e pressão fornecidos pelo aplicativo escolhe-se, pelos catálogos das principais empresas fabricantes de bombas no mercado, o conjunto moto-bomba que melhor se ajusta ao projeto de irrigação. Com a bomba selecionada o usuário, por meio da curva característica fornecida pelo fabricante, seleciona e digita 10 sequiências de dados de vazão, pressão e potência requerida, no maior rotor e na rotação original da bomba, nas respectivas células do quadro "BOMBA ORIGINAL" na planilha "Bomba". Com estes dados, são calculados a eficiência da bomba (\%) e o torque necessário ao motor $(\mathrm{N}$ m). $\mathrm{O}$ aplicativo permite ao usuário escolher, por meio de simulação, qual a composição entre diâmetro de rotor e rotação que melhor se ajusta aos requerimentos do projeto. Para tal digita-se a rotação e/ou o rotor da bomba desejados 
nas respectivas células (azul claro) no quadro "BOMBA 1" e verifica-se o resultado obtido, caso não seja satisfatório, deve-se substituir os valores digitados até obter o valor correto. Este ajuste pode ser executado de modo mais simples (automático) na planilha “Dim”, como será explicado adiante.

Caso o usuário deseje utilizar bombas associadas, deve escolher entre as opções "PARALELO" ou "SÉRIE" no quadro "TIPO DE ASSOCIAÇÃO” da "Bomba" e digitar os valores de rotação e do rotor da bomba, também no quadro "BOMBA 2". Ao escolher uma das opções de associação os valores de vazão ("VAZÃO 1", "VAZÃO 2" e "VAZÃO 1+2"), pressão ("PRESSÃO 1" e "PRESSÃO 2" e “PRESSÃO 1+2"), eficiência ("EFICIÊNCIA BOMBA 1" e "EFICIÊNCIA BOMBA 2") e potência ("POTÊNCIA 1", "POTÊNCIA 2" e "POTÊNCIA 1+2"), passam a ser visível nos respectivos quadros. Automaticamente o aplicativo calcula os novos pares de dados e fornece as equações das curvas de vazão x pressão, vazão x potência, vazão x eficiência e pressão x vazão no gráfico correspondente a cada quadro de modelo de bomba. Caso necessário o usuário deve ajustar, manualmente, as escalas dos gráficos. O aplicativo permite apenas associações de diâmetros de rotor diferentes; as rotações utilizadas devem ser iguais entre os modelos associados. A planilha permite ainda o cálculo do NPSH (net positive head suction).

As Figuras 16 e 17 mostram a planilha "Bomba", onde pode-se observar os quadros com os respectivos gráficos para simulação do bombeamento. 


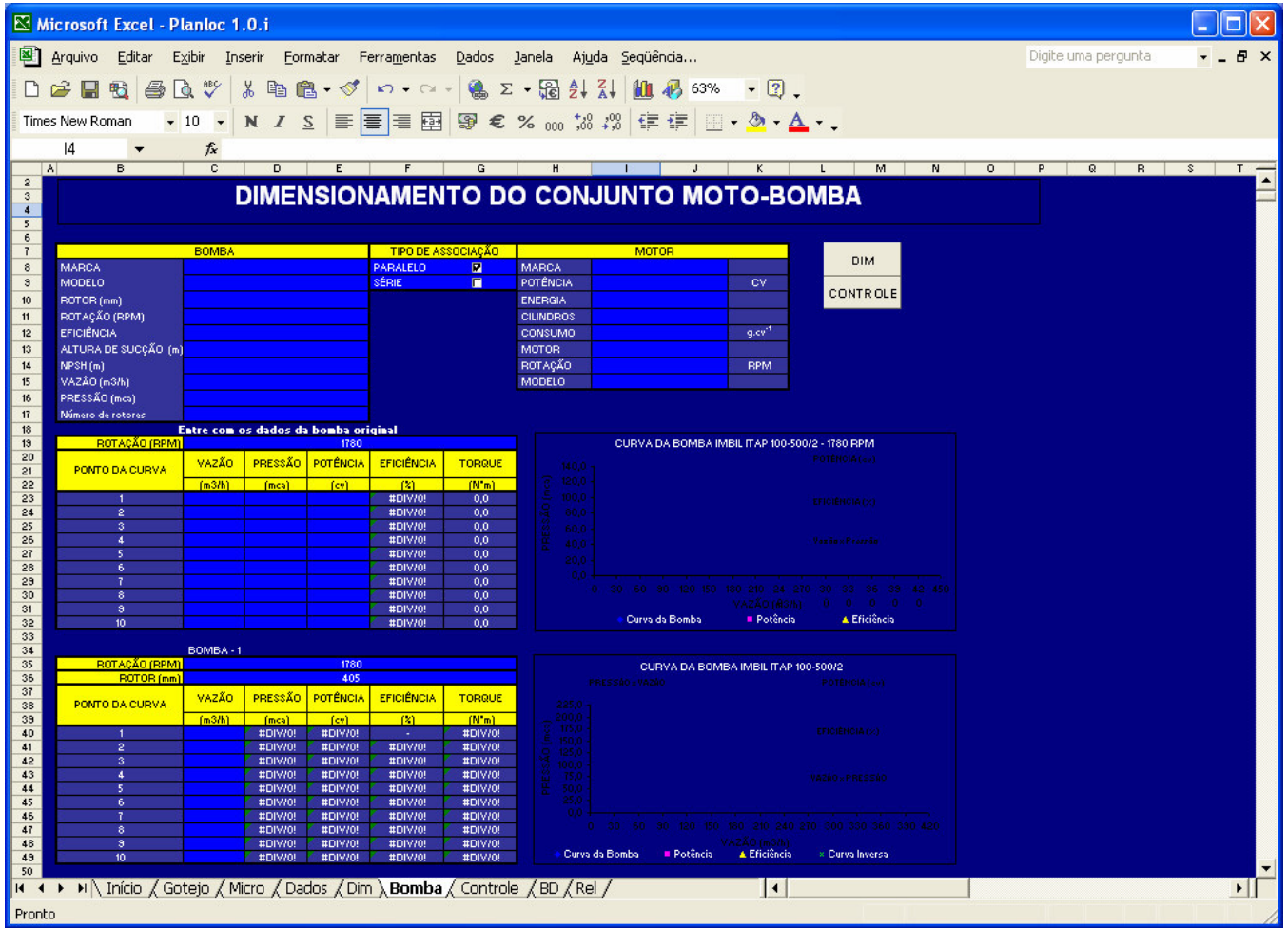

Figura 16 - Tela da planilha "Bomba"

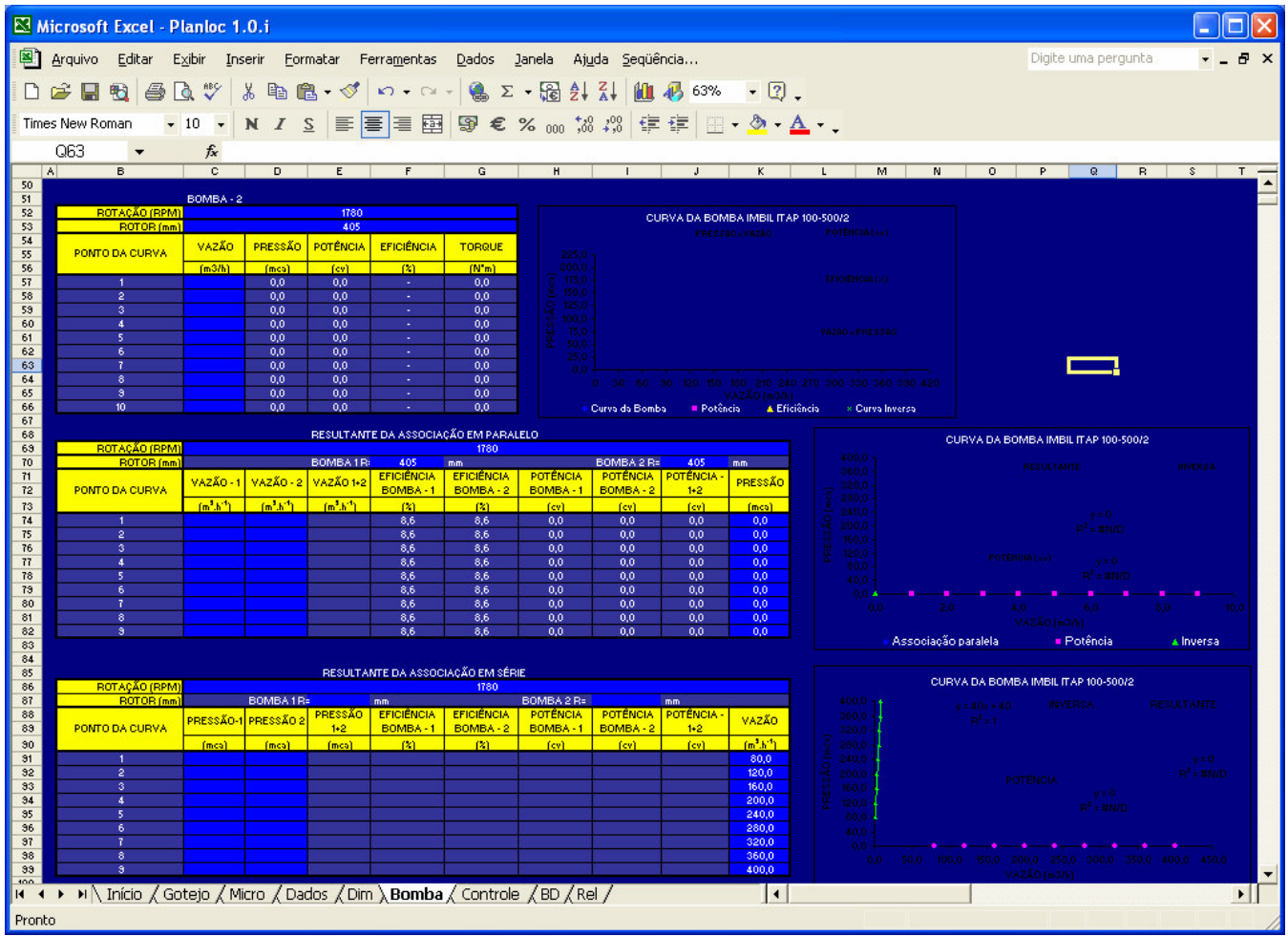

Figura 17 - Tela da planilha "Bomba" (continuação) 


\subsubsection{Ajuste da malha hidráulica ao conjunto moto-bomba}

Os parâmetros da equação da curva vazão x pressão ("A", "B", "C" e "D"), sejam eles resultantes de associação ou não, devem ser digitados nas células correspondentes na planilha "Dim" para o aplicativo calcular as pressões no final de cada trecho da tubulação, do ponto de bombeamento até o ponto crítico, considerando o sentido do fluxo da água. O usuário deve, ainda, digitar os valores do diâmetro do rotor e da rotação da bomba, utilizados no dimensionamento do bombeamento na planilha "Bomba", nas células denominadas "Atual" nos quadros "Diâmetro do rotor" e "Rotação" na planilha "Dim". Antes de iniciar os cálculos os valores acima devem ser copiados para as células "Requerido", nos respectivos quadros.

Com os valores de altura manométrica total e vazão total do projeto, determinados pelo cálculo "Requerido" (conforme descrito no item 4.1.4.), digitados nas células "Altura manométrica total" e "Vazão moto-bomba" pressiona-se o botão "DIÂMETRO ROTOR", para ajustar o diâmetro do rotor da bomba, ou o botão "ROTAÇÃO MOTOR" para ajustar a rotação da bomba à situação do projeto. Com todos os dados digitados pressiona-se o botão "FORNECIDO" para o aplicativo realizar os cálculos e fornecer a pressão (mca) e a vazão $\left(\mathrm{m}^{3} \mathrm{~h}^{-1}\right)$ no final de cada trecho, a perda de carga (mca) e a velocidade ( $\mathrm{m} \mathrm{s}^{-1}$ ) em cada trecho e a pressão mínima necessária na entrada de cada válvula (parcela). As planilhas acima descritas podem ser visualizadas por meio da Figura 18. 


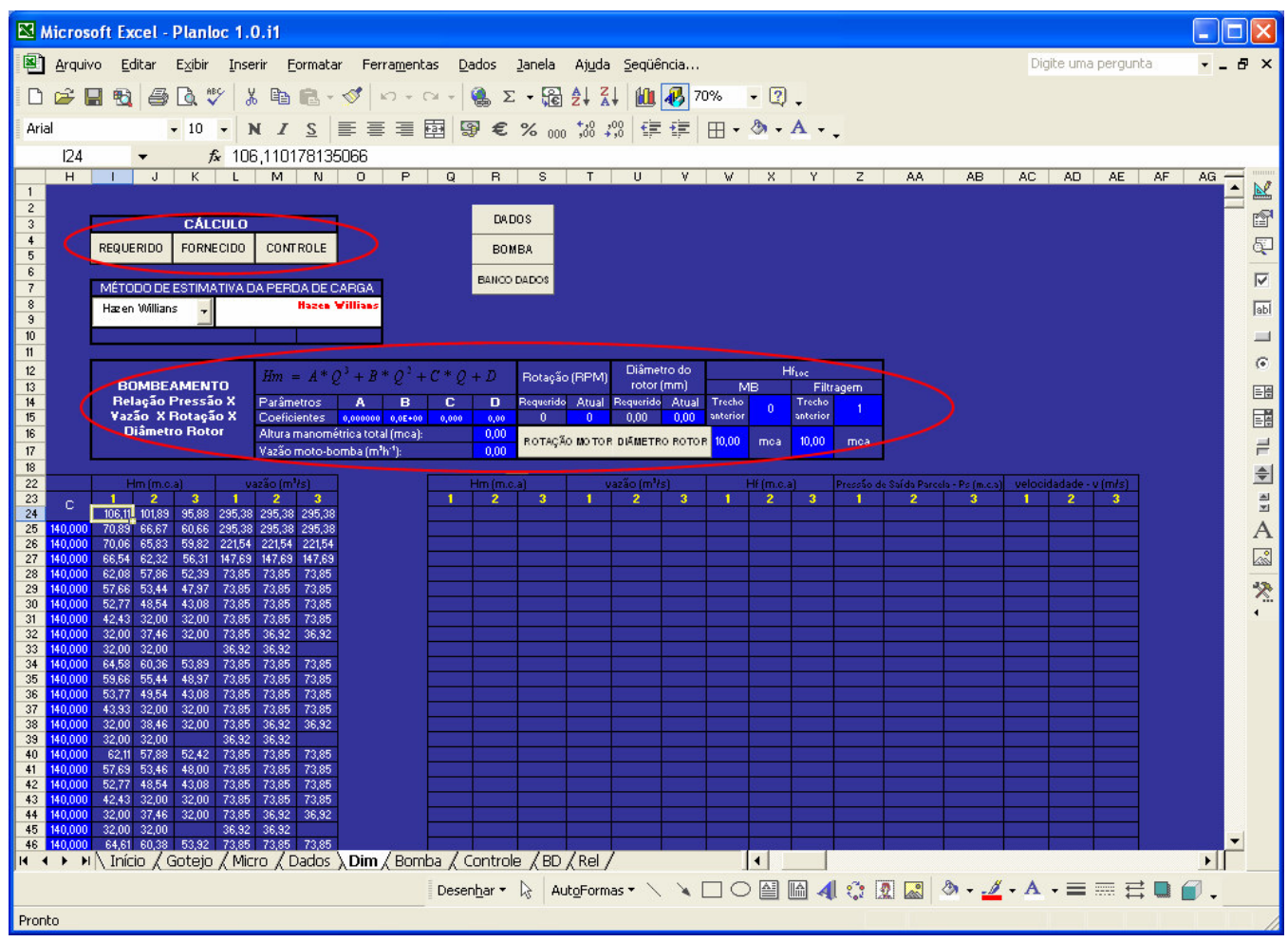

Figura 18 - Entrada de dados da simulação do bombeamento na planilha "Dim"

\subsubsection{Simulação de operação}

Para realizar as simulações de funcionamento do sistema de irrigação pressionase o botão "CONTROLE" na planilha "Dim". Nesta etapa o aplicativo cria uma nova planilha, denominada "Controle", contendo o quadro de funcionamento, onde se deve digitar a letra "xis" em maiúsculo nas células em azul claro, correspondentes às parcelas que se deseja operar. Para realizar os cálculos e visualizar os resultados o usuário deve pressionar o botão "CALCULAR”.

Com a nova situação de operação simulada, verifica-se a necessidade de ajustar o funcionamento do conjunto moto-bomba, em função das pressões na malha hidráulica (pressão superior à classe de pressão ou pressões inferiores às necessárias nas parcelas). Caso haja necessidade, os dados obtidos de altura manométrica total e vazão total requeridos, para a nova situação, devem ser digitados nas respectivas células na planilha 
"Dim". Como, neste caso, o sistema está dimensionado, pressiona-se o botão "ROTAÇÃO MOTOR" para adequar o ponto de trabalho do conjunto moto-bomba. No caso de dimensionamento de projetos novos, pode-se adotar um novo diâmetro de rotor (maior) e um novo motor (mais potente) para atender à maioria das situações de funcionamento. Com a rotação ajustada deve-se retornar à planilha "Controle" e pressionar novamente o botão "CALCULAR" para simular os novos valores de pressão. Este processo de ajuste é realizado por tentativa e erro. $\mathrm{O}$ aplicativo permite, no caso de associações de bombas, executar as simulações para apenas uma das bombas em operação, para tal, o usuário deve substituir os parâmetros da equação da bomba e os valores das células "Altura manométrica total" e "Vazão moto-bomba" na planilha "Dim", pressionar o botão "ROTAÇÀO MOTOR", caso necessário, retornar à planilha controle e pressionar o botão "CALCULAR". A Figura 19 mostra a tela da planilha "Controle".

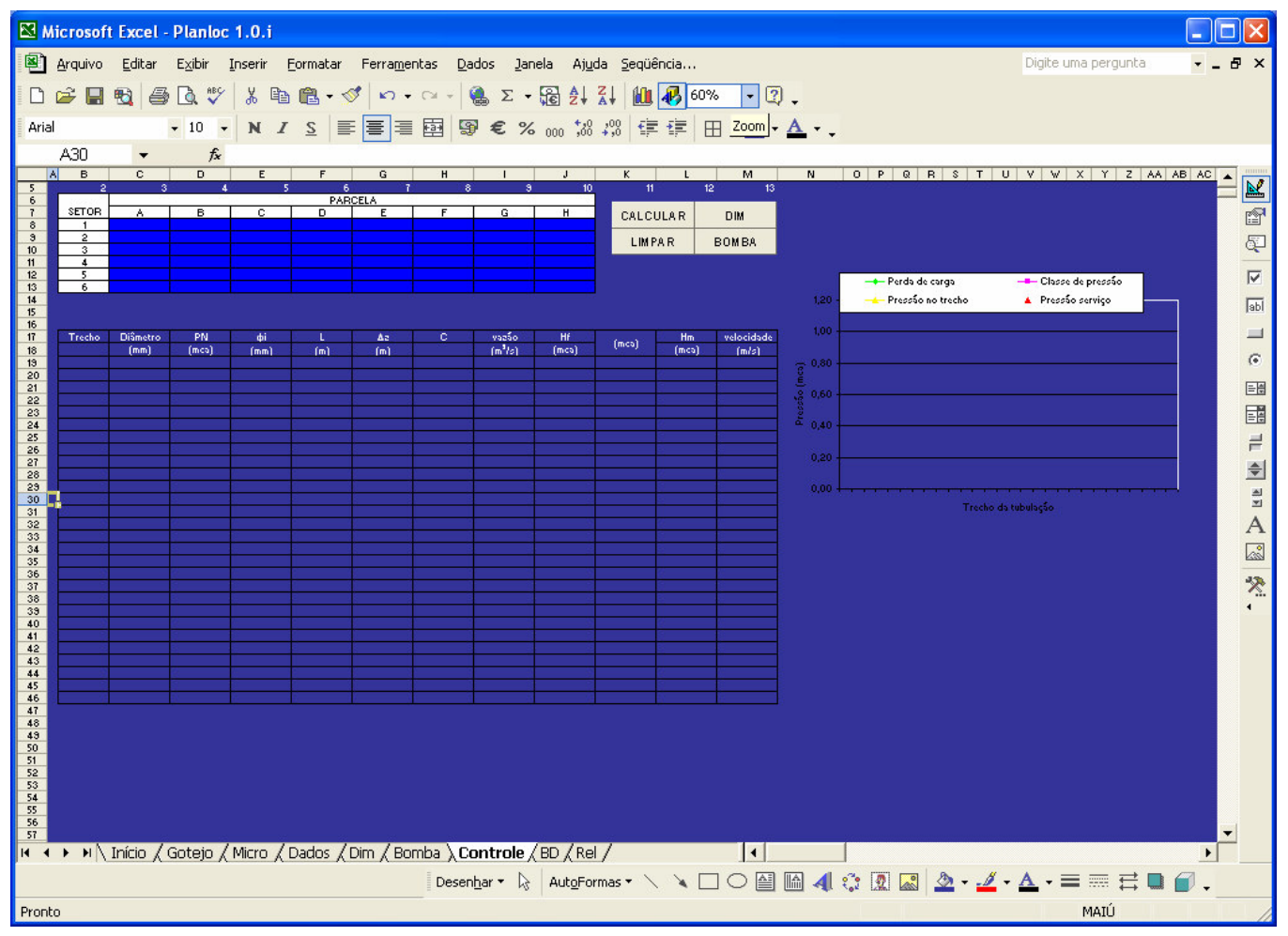

Figura 19 - Tela da planilha "Controle" 


\subsection{Simulação do aplicativo PLANLOC 1.0}

\subsubsection{Descrição do layout do projeto}

O projeto de irrigação foi dividido em 48 parcelas de 3,0 ha cada, agrupadas em 6 unidades de funcionamento (setores), a malha hidráulica foi dividida em 27 trechos com diâmetros de tubulação variando de 100 a $250 \mathrm{~mm}$, classe de pressão entre 60 e 125 mca e comprimentos entre 75 e $475 \mathrm{~m}$. A Tabela 8 mostra para cada trecho do projeto o trecho anterior, a vazão, o comprimento, a diferença de nível entre o início e o final do trecho, o diâmetro e a classe de pressão da tubulação, e as parcelas que são abastecidas pela vazão que passa no respectivo trecho. Pode-se observar na composição dos trechos componentes do sistema que o trecho 3 é um ponto de divisão da malha hidráulica, pois é anterior ao trecho 4 e ao trecho 10, o mesmo acontece com os trechos 1 e 2, que são anteriores aos trechos 22 e 16, respectivamente.

Tabela 8. Distribuição das tubulações nos trechos do projeto

\begin{tabular}{ccccrcc}
\hline Trecho & $\begin{array}{c}\text { Trecho } \\
\text { Anterior }\end{array}$ & $\begin{array}{c}\text { Vazão } \\
\mathrm{m}^{3} \cdot \mathrm{h}^{-1}\end{array}$ & $\begin{array}{c}\text { Comprimento } \\
\mathrm{m}\end{array}$ & $\begin{array}{c}\text { D. nível } \\
\mathrm{m}\end{array}$ & $\begin{array}{c}\text { DN/PN } \\
\mathrm{mm} / \mathrm{mca}\end{array}$ & Parcelas \\
\hline 0 & - & 295,38 & & Moto-bomba & Todas \\
1 & 0 & 295,38 & 300,00 & 16,20 & $250 / 125$ & Todas \\
2 & 1 & 221,54 & 400,00 & $-1,00$ & $250 / 80$ & Setores B,C,D,F,G,H \\
3 & 2 & 147,69 & 416,00 & 1,00 & $200 / 80$ & Setores A,C,D,E,G,H \\
4 & 3 & 73,85 & 475,00 & 1,00 & $150 / 80$ & Setores D e H \\
5 & 4 & 73,85 & 150,00 & 3,50 & $150 / 80$ & 1D a 6D e 1H a 4H \\
6 & 5 & 73,85 & 150,00 & 4,00 & $150 / 60$ & 1D a 6D e 1H e 2H \\
7 & 6 & 36,92 & 166,00 & 4,50 & $100 / 60$ & 1D a 6D \\
8 & 7 & 36,92 & 150,00 & 3,50 & $100 / 60$ & 1D a 4D \\
9 & 8 & 36,92 & 150,00 & 4,00 & $100 / 60$ & 1D e 2D \\
10 & 3 & 73,85 & 75,00 & 1,50 & $150 / 80$ & Setores C e G \\
11 & 10 & 73,85 & 150,00 & 4,00 & $150 / 80$ & 1C a 6C e 1G a 4G \\
12 & 11 & 73,85 & 150,00 & 5,00 & $150 / 60$ & 1C a 6C e 1G e 2G \\
13 & 12 & 36,92 & 166,00 & 4,00 & $100 / 60$ & 1C a 6C
\end{tabular}


Tabela 8. Distribuição das tubulações nos trechos do projeto

\begin{tabular}{ccccccc}
\hline Trecho & $\begin{array}{c}\text { Trecho } \\
\text { Anterior }\end{array}$ & $\begin{array}{c}\text { Vazão } \\
\mathrm{m}^{3} \cdot \mathrm{h}^{-1}\end{array}$ & $\begin{array}{c}\text { Comprimento } \\
\mathrm{m}\end{array}$ & $\begin{array}{c}\text { D. nível } \\
\mathrm{m}\end{array}$ & $\begin{array}{c}\text { DN/PN } \\
\mathrm{mm} / \mathrm{mca}\end{array}$ & Parcelas \\
\hline 14 & 13 & 36,92 & 150,00 & 4,00 & $100 / 60$ & $1 \mathrm{C}$ a 4C \\
15 & 14 & 36,92 & 150,00 & 5,00 & $100 / 60$ & 1C e 2C \\
16 & 2 & 73,85 & 75,00 & 2,00 & $150 / 80$ & Setores B e F \\
17 & 16 & 73,85 & 150,00 & 3,50 & $150 / 80$ & 1B a 6B e 1F a 4F \\
18 & 17 & 73,85 & 150,00 & 4,00 & $150 / 80$ & 1B a 6B e 1F e 2F \\
19 & 18 & 36,92 & 166,00 & 4,50 & $100 / 60$ & 1 B a 6B \\
20 & 19 & 36,92 & 150,00 & 3,50 & $100 / 60$ & 1 1B a 4B \\
21 & 20 & 36,92 & 150,00 & 4,00 & $100 / 60$ & 1B e 2B \\
22 & 1 & 73,85 & 75,00 & 1,50 & $150 / 80$ & Setores A e E \\
23 & 22 & 73,85 & 150,00 & 4,00 & $150 / 80$ & 1A a 6A e 1E a 4E \\
24 & 23 & 73,85 & 150,00 & 5,00 & $150 / 80$ & 1A a 6A e 1E e 2E \\
25 & 24 & 36,92 & 166,00 & 4,00 & $100 / 60$ & 1A a 6A \\
26 & 25 & 36,92 & 150,00 & 4,00 & $100 / 60$ & 1A a 4A \\
27 & 26 & 36,92 & 150,00 & 5,00 & $100 / 60$ & 1A e 2A \\
\hline
\end{tabular}

\subsubsection{Dimensionamento}

Utilizando a fórmula de Hazen-Williams para dimensionamento do projeto de irrigação, como se pode observar pela Figura 20, a pressão e vazão máxima requerida pelo sistema foi de 100,4 mca e 295,38 $\mathrm{m}^{3} \mathrm{~h}^{-1}$, respectivamente, nos setores 1 e 2 . Nos setores 3 e 4 a pressão e a vazão requerida pelo sistema foi 98,2 mca e $295,38 \mathrm{~m}^{3} \mathrm{~h}^{-1}$ e para os setores 5 e 6 foram obtidos 92,6 mca e $295,38 \mathrm{~m}^{3} \mathrm{~h}^{-1}$, respectivamente.

Utilizando a fórmula Universal (Darcy-Weisbach), para o dimensionamento do projeto de irrigação, considerando água a $20^{\circ} \mathrm{C}$ e rugosidade relativa $(\varepsilon)$ a $0,006 \mathrm{~mm}$ para PVC, os valores de vazão e pressão requeridos pelo sistema obtidos foram: 99,4 mca e 295,38 $\mathrm{m}^{3} \mathrm{~h}^{-1}$ para os setores 1 e $2 ; \quad 96,2$ mca e $295,38 \mathrm{~m}^{3} \mathrm{~h}^{-1}$ para os setores 3 e 4; 90,9 mca e $295,38 \mathrm{~m}^{3} \mathrm{~h}^{-1}$ para os setores 5 e 6 , respectivamente.

Pode- se observar que nos dois casos a maior demanda ocorreu nos setores 1 e 2 e pode ser justificada pelo posicionamento das parcelas na área, ou seja, são os pontos 
mais altos e mais distantes da moto-bomba. Para diminuir a variação das pressões requeridas entre os setores de irrigação pode-se modificar a divisão dos setores, ou seja, diminuir o tamanho e, conseqüentemente a vazão e a perda de carga, dos setores críticos, e aumentar o tamanho dos setores mais próximos à moto-bomba.

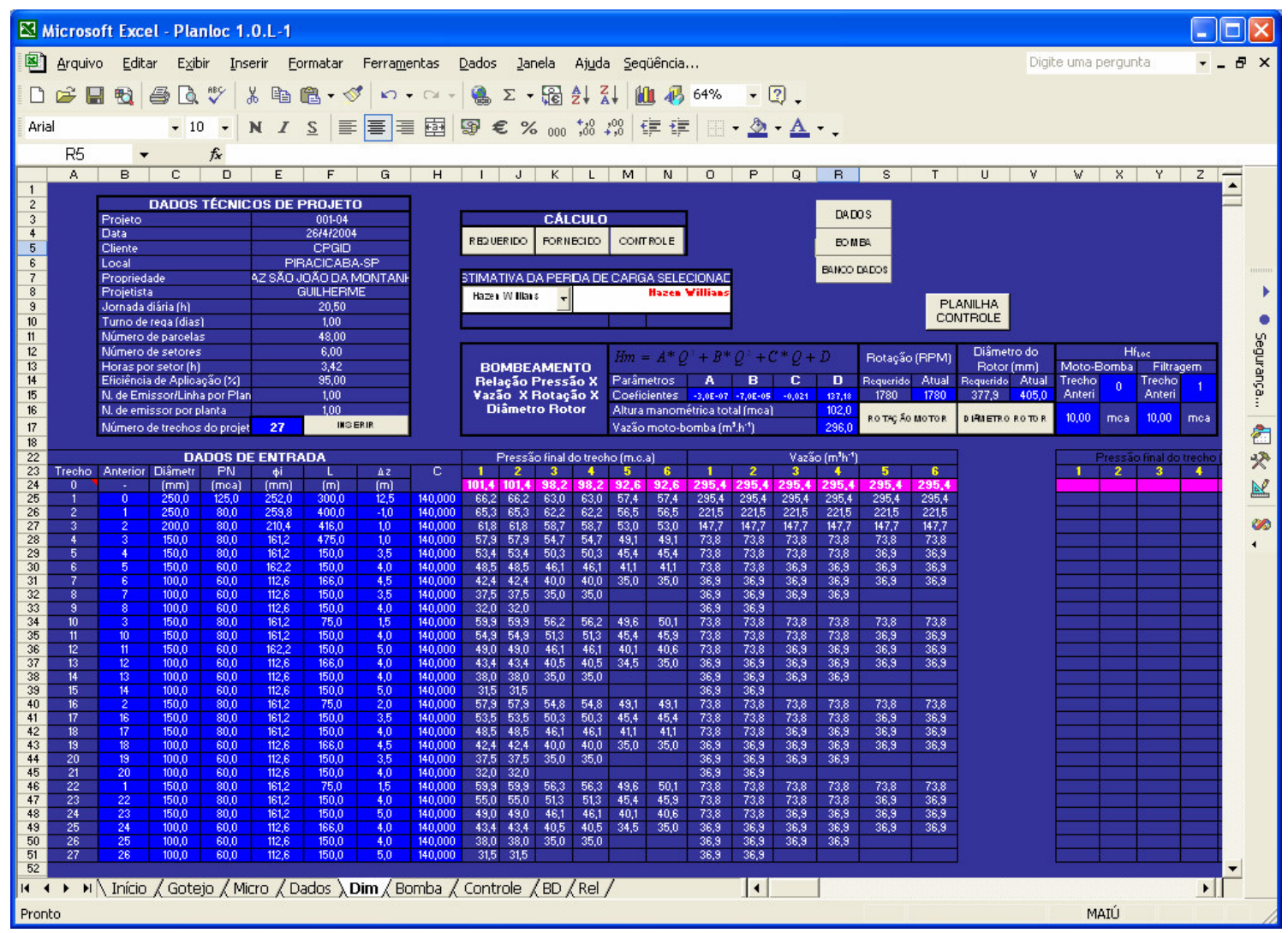

Figura 20 - Pressões e vazões requeridas para cada trecho nos seis setores de irrigação

\subsubsection{Bombeamento}

O sistema de bombeamento projetado é composto por dois conjuntos (motobomba diesel) associados em paralelo com as seguintes características: bomba marca Imbil, modelo ITAP 100-500/2 com rotor de $377,9 \mathrm{~mm}$ a $1.780 \mathrm{RPM}$; motor diesel marca MWM, modelo D 229-6, natural com seis cilindros, potência contínua de 67,11 KW, torque de 314,8 N.m e consumo específico de 162,0 g.(cv.h) ${ }^{-1}$ a 1.780 RPM.

Pode-se observar pelas Tabelas 9, 10 e 11 os parâmetros do conjunto moto-bomba para o rotor original da bomba (405 mm) em sua rotação nominal (1780 RPM), para a 
associação em paralelo e para o diâmetro de rotor de 377,9 mm e pelas Figuras 21, 22 e 23 as equações das curvas ajustadas dos parâmetros do conjunto moto-bomba em cada uma das opções analisadas.

Tabela 9. Parâmetros do conjunto moto-bomba Imbil ITAP 100-500/2 com diâmetro de rotor de $405 \mathrm{~mm}$ e $1780 \mathrm{RPM}$

\begin{tabular}{cccccc}
\hline $\begin{array}{c}\text { Ponto da } \\
\text { curva }\end{array}$ & $\begin{array}{c}\text { Vazão } \\
\mathrm{m}^{3} \mathrm{~h}^{-1}\end{array}$ & $\begin{array}{c}\text { Pressão } \\
\mathrm{mca}\end{array}$ & $\begin{array}{c}\text { Potência } \\
\mathrm{cv}\end{array}$ & $\begin{array}{c}\text { Eficiência } \\
\%\end{array}$ & $\begin{array}{c}\text { Torque } \\
\mathrm{N} \mathrm{m}\end{array}$ \\
\hline 1 & 20,0 & 136,0 & 44,0 & 22,9 & 173,7 \\
2 & 40,0 & 135,0 & 55,0 & 36,4 & 217,2 \\
3 & 60,0 & 133,0 & 63,0 & 46,9 & 248,8 \\
4 & 80,0 & 131,0 & 68,0 & 57,1 & 268,5 \\
5 & 100,0 & 128,0 & 73,6 & 64,4 & 290,6 \\
6 & 120,0 & 124,0 & 80,5 & 68,5 & 317,9 \\
7 & 140,0 & 119,0 & 88,0 & 70,1 & 347,5 \\
8 & 160,0 & 113,5 & 94,0 & 71,6 & 371,2 \\
9 & 180,0 & 106,5 & 100,0 & 71,0 & 394,8 \\
10 & 200,0 & 98,0 & 105,0 & 69,1 & 414,6 \\
\hline
\end{tabular}

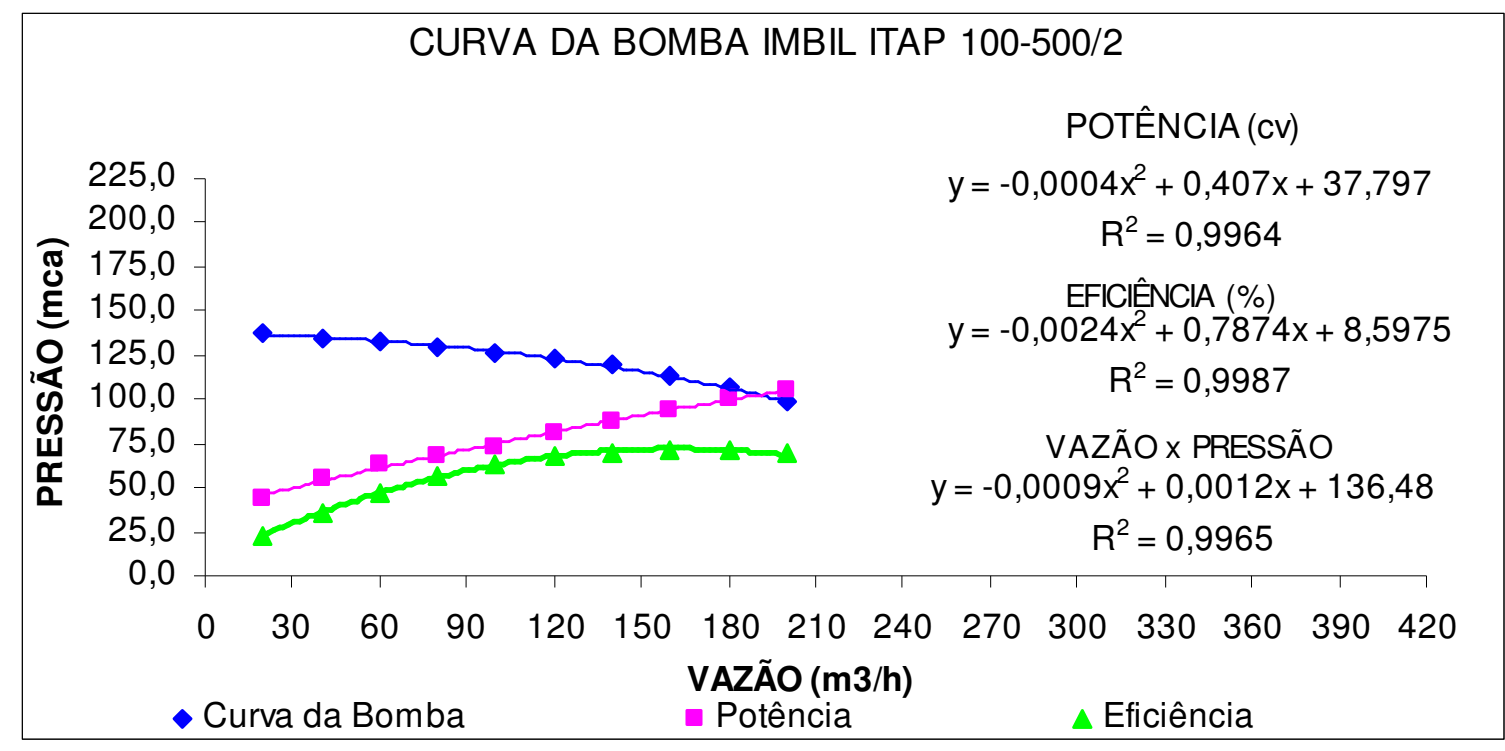

Figura 21 - Ajuste das equações das curvas dos parâmetros do conjunto moto-bomba com diâmetro de rotor de 405 mm e 1780 RPM 
Tabela 10. Parâmetros da associação em paralelo de dois conjuntos moto-bomba Imbil ITAP 100-500/2 com diâmetro de rotor de 405 mm e 1780 RPM

\begin{tabular}{ccccc}
\hline $\begin{array}{c}\text { Ponto da } \\
\text { curva }\end{array}$ & $\begin{array}{c}\text { Vazão } \\
\mathrm{m}^{3} \mathrm{~h}^{-1}\end{array}$ & $\begin{array}{c}\text { Pressão } \\
\text { mca }\end{array}$ & $\begin{array}{c}\text { Potência } \\
\mathrm{cv}\end{array}$ & $\begin{array}{c}\text { Eficiência } \\
\%\end{array}$ \\
\hline 1 & 80,0 & 135,0 & 110,2 & 36,3 \\
2 & 120,0 & 133,0 & 124,9 & 47,3 \\
3 & 160,0 & 131,0 & 137,8 & 56,3 \\
4 & 200,0 & 128,0 & 149,6 & 63,4 \\
5 & 240,0 & 124,0 & 161,2 & 68,4 \\
6 & 280,0 & 119,0 & 172,8 & 71,4 \\
7 & 320,0 & 113,5 & 185,7 & 72,4 \\
8 & 360,0 & 106,5 & 198,7 & 71,5 \\
9 & 400,0 & 98,0 & 211,9 & 68,5 \\
\hline
\end{tabular}

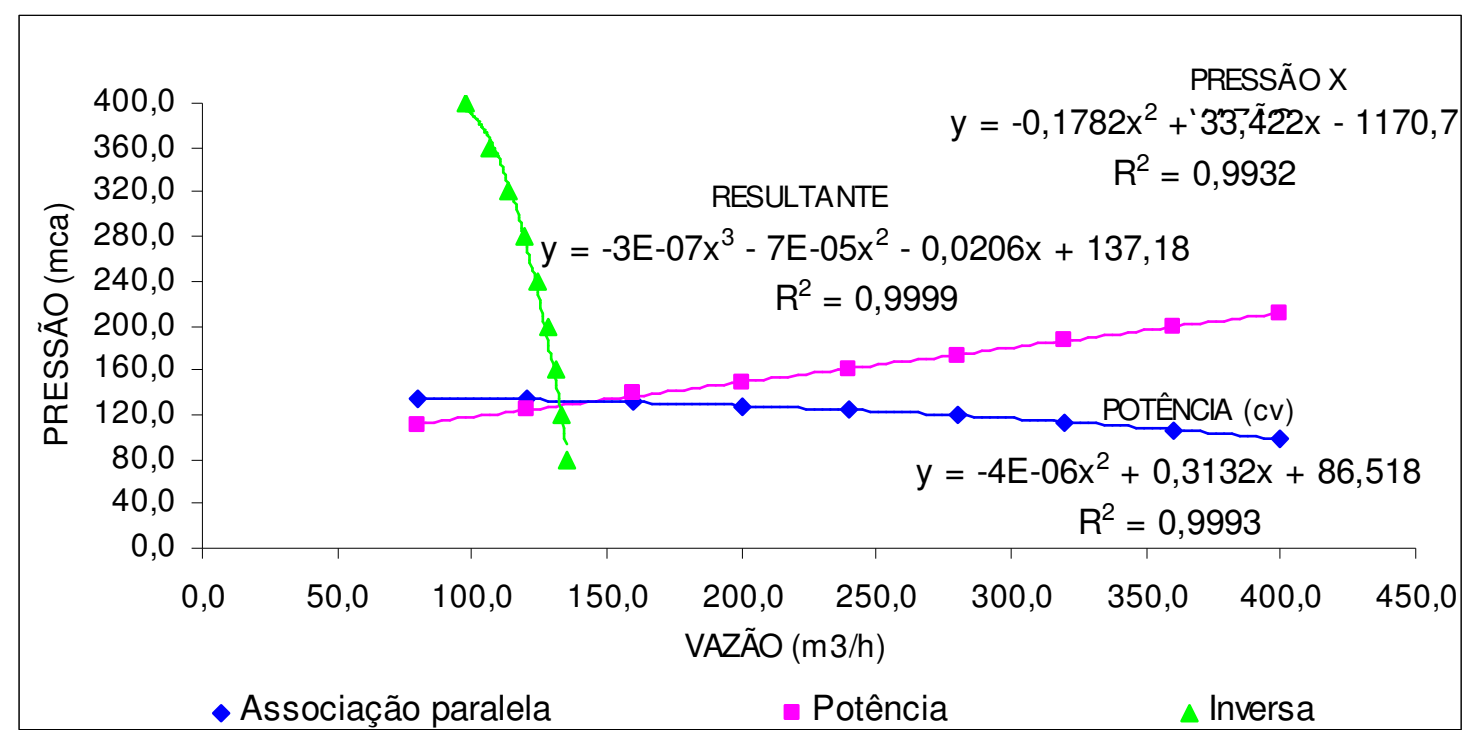

Figura 22 - Ajuste das equações das curvas dos parâmetros da associação em paralelo dos dois conjuntos moto-bomba, com diâmetro de rotor de $405 \mathrm{~mm}$ e 1780 RPM 
Tabela 11. Parâmetros do conjunto moto-bomba Imbil ITAP 100-500/2 com diâmetro de rotor de $377,9 \mathrm{~mm}$ e $1780 \mathrm{RPM}$

\begin{tabular}{cccccc}
\hline $\begin{array}{c}\text { Ponto da } \\
\text { curva }\end{array}$ & $\begin{array}{c}\text { Vazão } \\
\mathrm{m}^{3} \mathrm{~h}^{-1}\end{array}$ & $\begin{array}{c}\text { Pressão } \\
\text { mca }\end{array}$ & $\begin{array}{c}\text { Potência } \\
\mathrm{cv}\end{array}$ & $\begin{array}{c}\text { Eficiência } \\
\%\end{array}$ & $\begin{array}{c}\text { Torque } \\
\mathrm{N} \mathrm{m}\end{array}$ \\
\hline 1 & 20,0 & 118,4 & 38,3 & 22,9 & 151,3 \\
2 & 40,0 & 117,5 & 47,9 & 36,4 & 189,1 \\
3 & 60,0 & 115,8 & 44,9 & 46,9 & 216,6 \\
4 & 80,0 & 114,1 & 59,2 & 57,1 & 233,8 \\
5 & 100,0 & 111,4 & 64,1 & 64,4 & 253,0 \\
6 & 120,0 & 108,0 & 70,1 & 68,5 & 276,7 \\
7 & 140,0 & 103,6 & 76,6 & 70,1 & 302,5 \\
8 & 160,0 & 98,8 & 81,1 & 71,6 & 323,1 \\
9 & 180,0 & 92,7 & 87,1 & 71,0 & 343,8 \\
10 & 200,0 & 85,3 & 91,4 & 69,1 & 361,0 \\
\hline
\end{tabular}

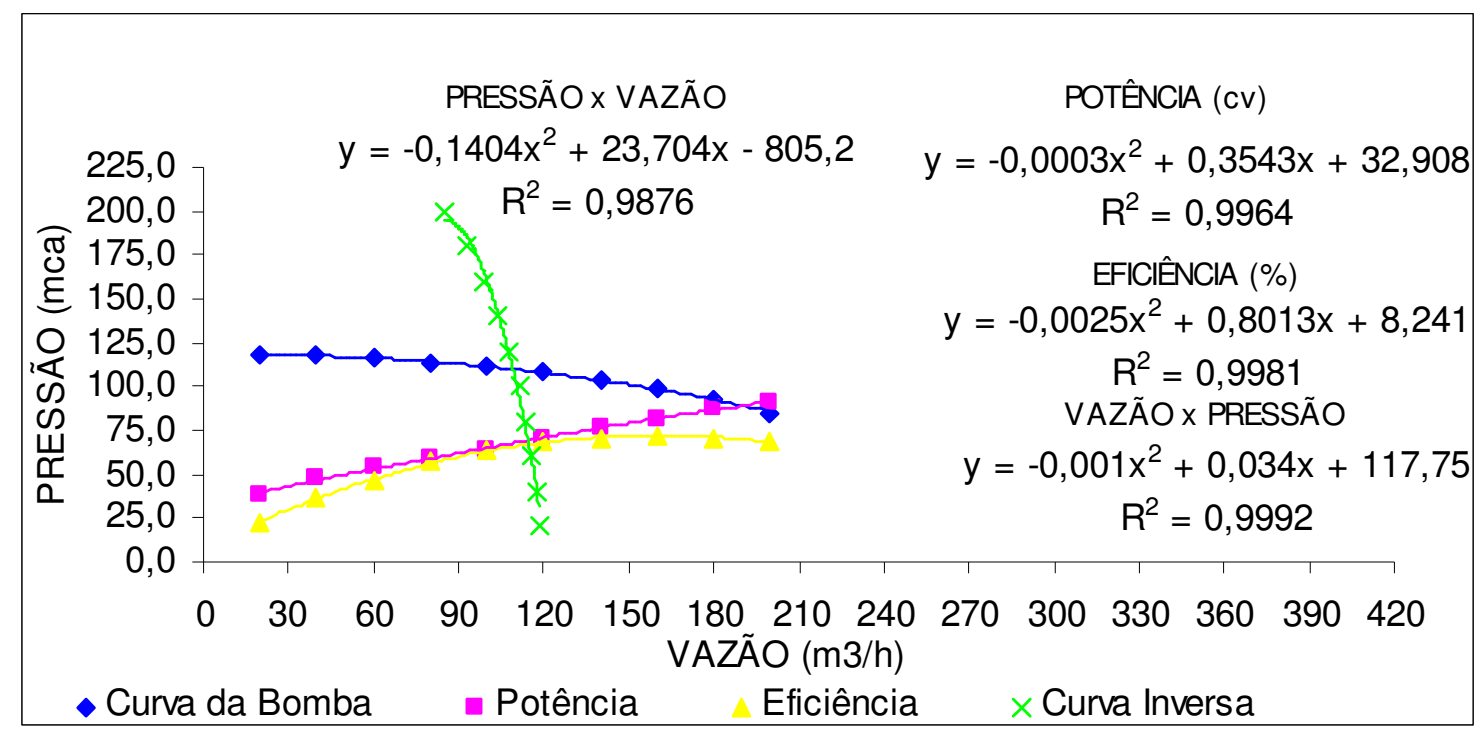

Figura 23 - Ajuste das equações das curvas dos parâmetros do conjunto moto-bomba com diâmetro de rotor de 377,9 mm e 1780 RPM 


\subsubsection{Malha hidráulica}

A Figura 24 mostra os valores calculados pelo aplicativo, no sentido do fluxo da água para os seis setores de irrigação, de altura manométrica total, pressão e vazão no final de cada trecho, perda de carga na tubulação, pressão mínima na entrada da parcela e velocidade da água na tubulação. pode-se observar que todos os valores estão dentro das classes de pressão da tubulação e as velocidades abaixo de $2,0 \mathrm{~m} \mathrm{~s}^{-1}$.

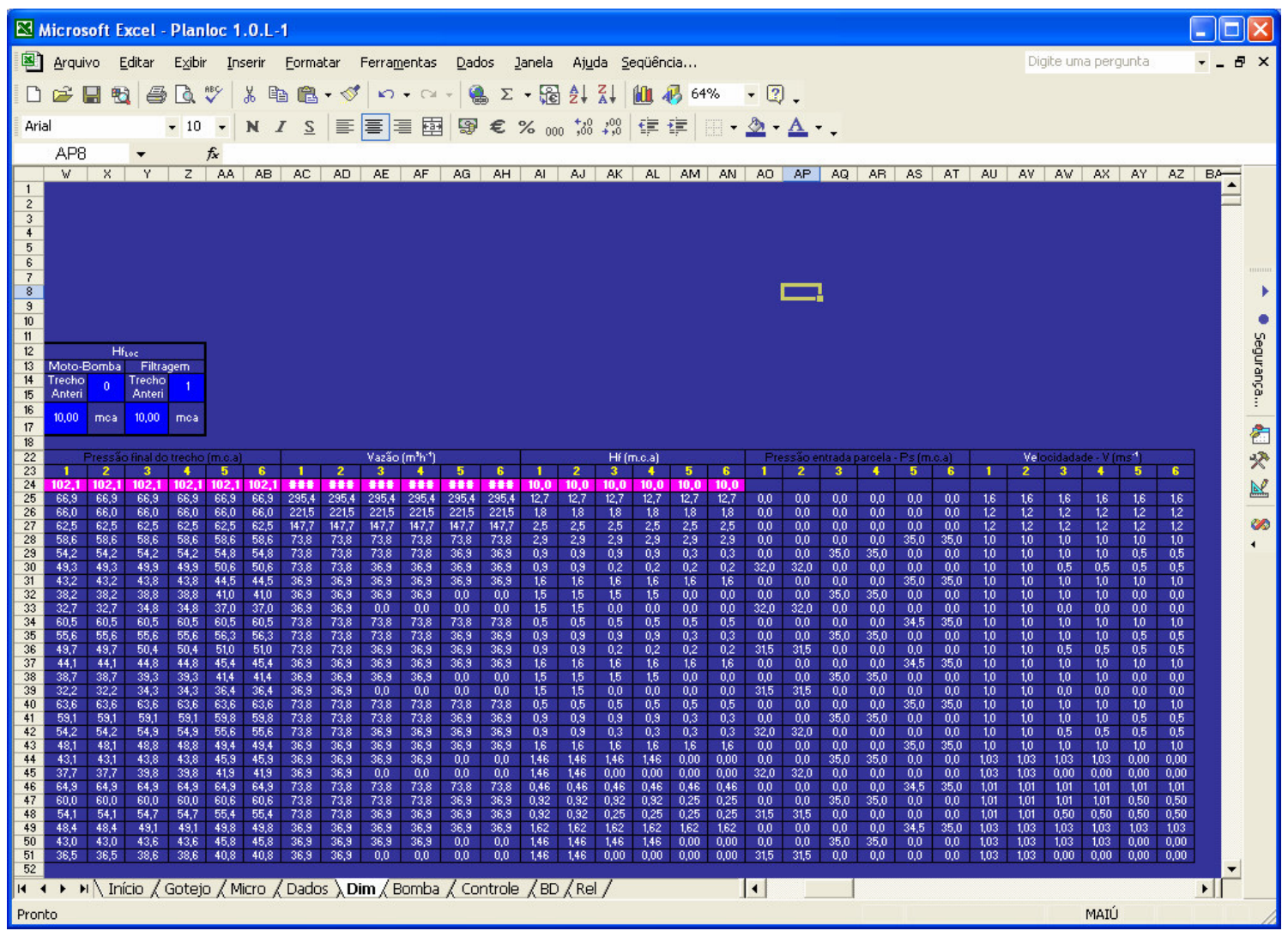

Figura 24 - Dimensionamento do sistema no sentido do fluxo da água, para cada trecho nos seis setores de funcionamento do sistema de irrigação

As Figuras 26, 27 e 28 mostram respectivamente, os gráficos do diâmetro, classe de pressão e perda de carga da tubulação, as pressões mínimas necessárias na entrada das parcelas e as pressões no final de cada trecho da tubulação, para os setores 1 e 2, 3 e 4 e 5 e 6. 


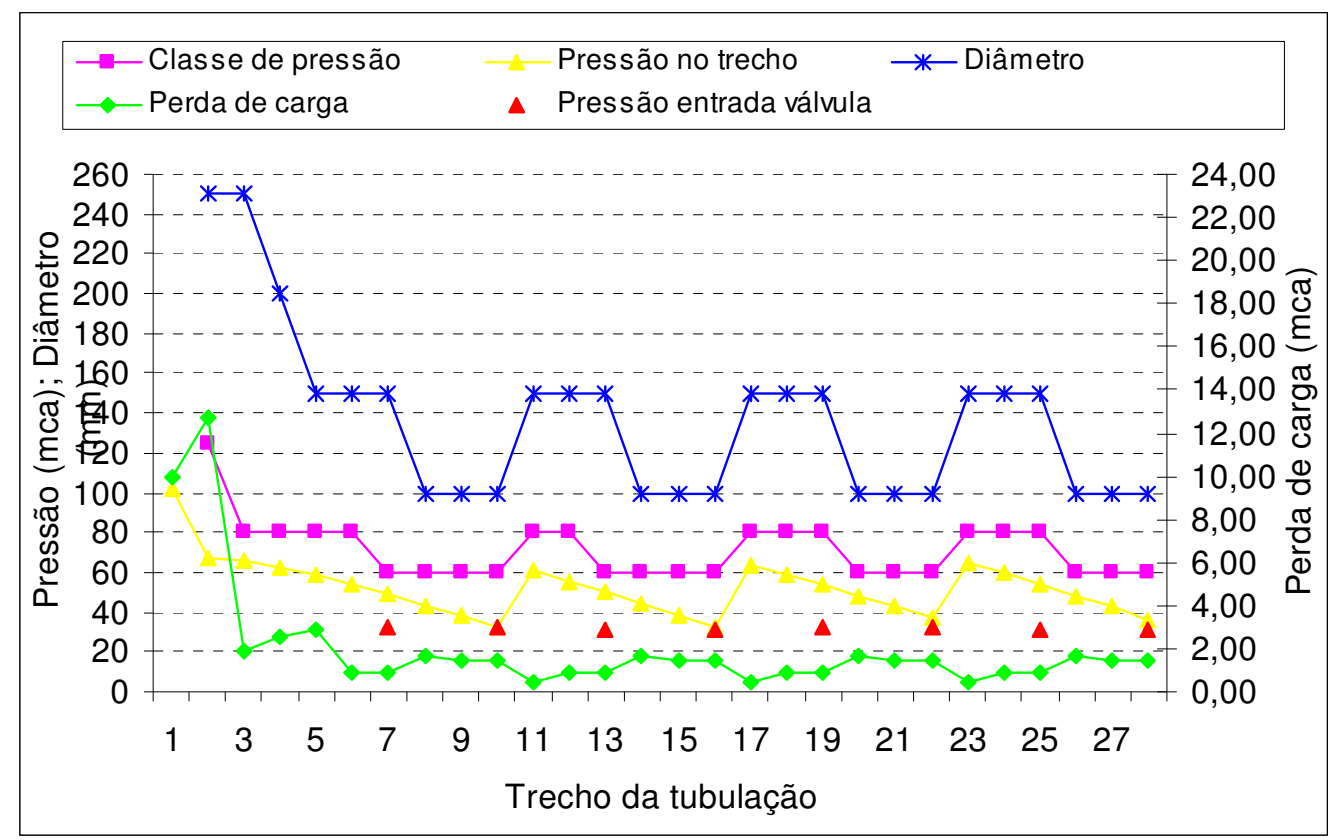

Figura 25 - Perda de carga, diâmetro da tubulação, classe de pressão, pressão de serviço na entrada da parcela e pressão ao longo dos trechos da tubulação calculados para os setores 1 e 2

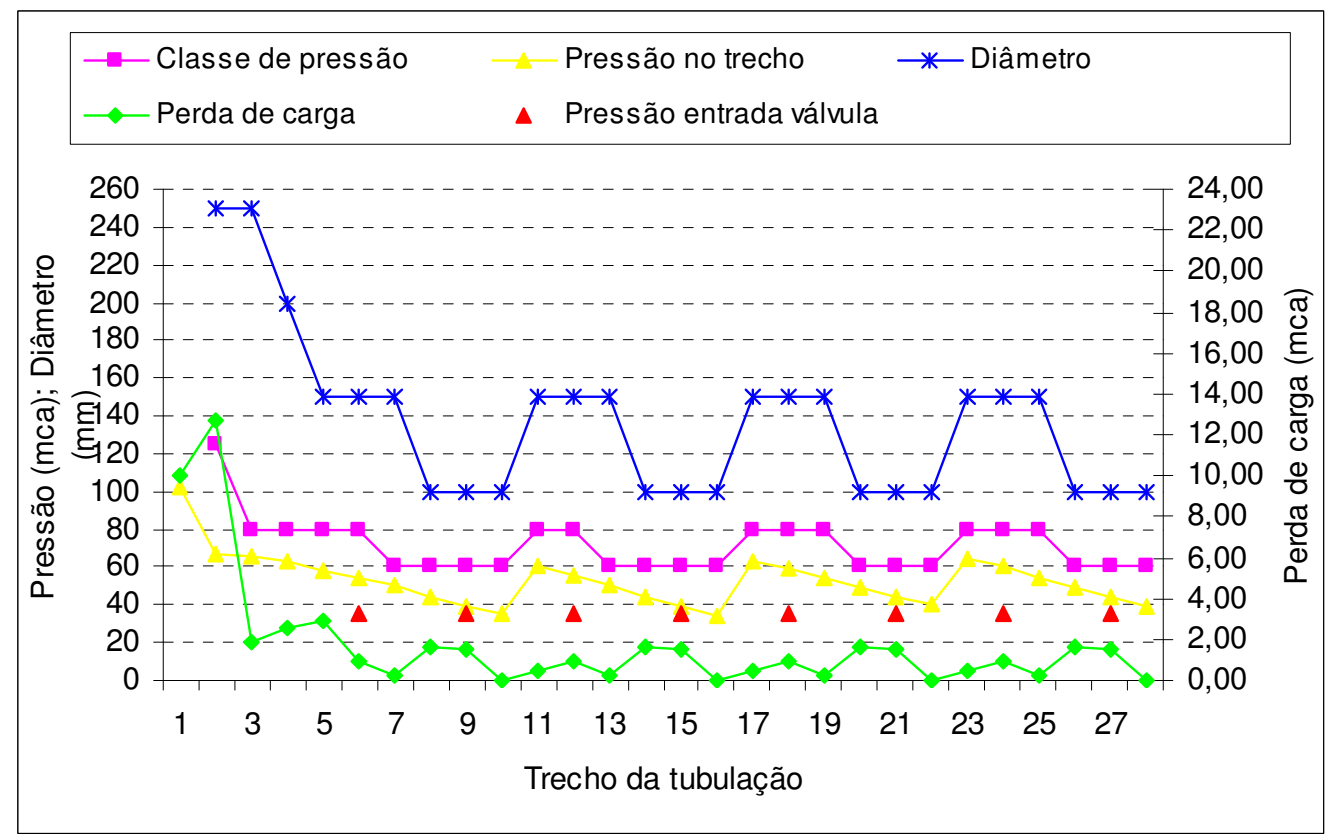

Figura 26 - Perda de carga, diâmetro da tubulação, classe de pressão, pressão de serviço na entrada da parcela e pressão ao longo dos trechos da tubulação calculados para os setores 3 e 4 


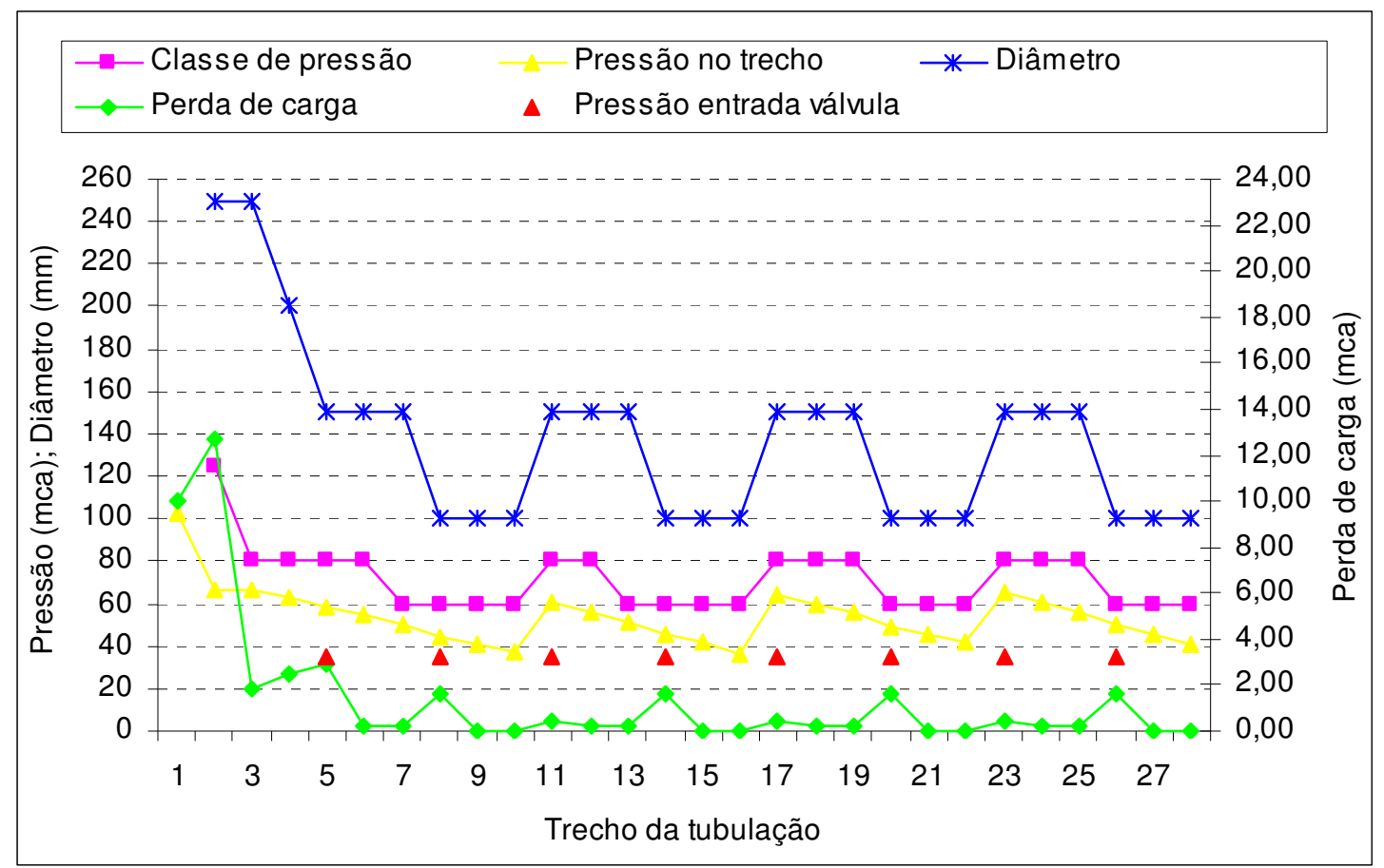

Figura 27 - Perda de carga, diâmetro da tubulação, classe de pressão, pressão de serviço na entrada da parcela e pressão ao longo dos trechos da tubulação calculados para os setores 5 e 6

\subsubsection{Simulação 1: Operação do sistema sem irrigar uma variedade}

Para executar a simulação e analisar os efeitos na malha hidráulica do projeto, considerou-se a eliminação da variedade de laranja natal, correspondente às parcelas $\mathrm{C} e$ D do projeto de irrigação original, com objetivo de promover um estresse hídrico para indução do florescimento fora de época. Como se pode observar na Figura 28, com a eliminação das parcelas, a vazão do projeto diminuiu de 296,0 para $221,5 \mathrm{~m}^{3} \mathrm{~h}^{-1}$ e, conseqüentemente a pressão aumentou de 102,0 para 109,62 mca, promovendo uma sobre-pressão (62,8 a 64,7 mca) nos trechos 6 e 12 (diâmetro de $150 \mathrm{~mm}$ e classe de pressão PN 60) no funcionamento dos setores 1 a 4 e também (60,2 mca) no trecho 7 (diâmetro de 100 mm e classe de pressão PN 60) quando funcionou os setores 5 e $6 . \mathrm{Na}$ prática os valores acima da classe de pressão (em torno de 5,0 mca) não devem ser suficientes para danificar o material, porém as empresas não fornecem garantia sobre 
seu funcionamento. Para corrigir este problema alterou-se, por meio do aplicativo a rotação do conjunto moto-bomba para 1717 rpm, o que eliminou o excesso de pressão nos trechos anteriormente citados.

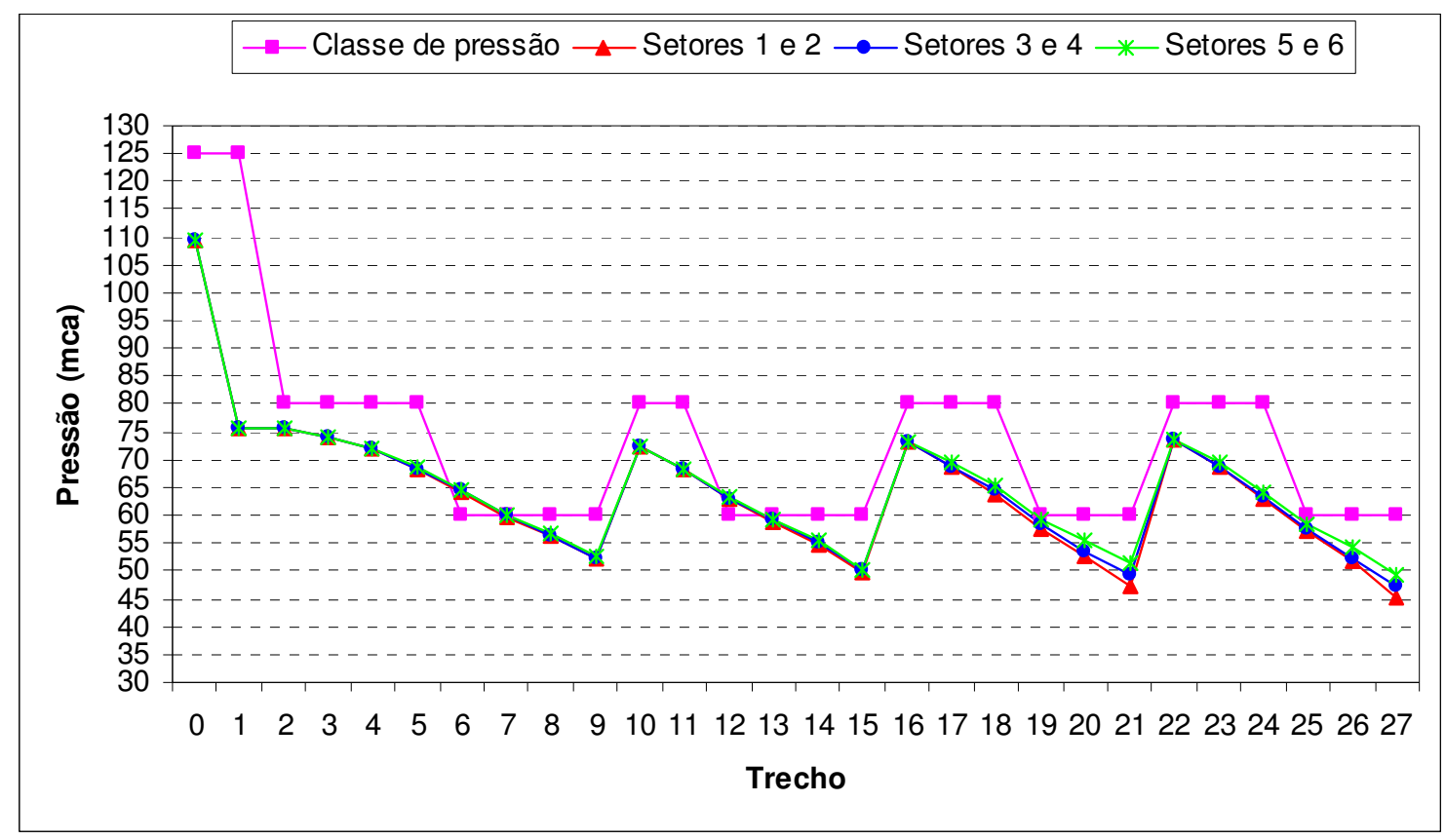

Figura 28 - Gráfico comparativo entre classe de pressão e pressão no final dos trechos da tubulação para simulação 1

\subsubsection{Simulação 2: Operação do sistema sem irrigar duas variedades}

Para executar a segunda simulação de funcionamento do projeto, considerou-se a opção de não irrigar as variedades de laranja natal e pêra rio, correspondente às parcelas C, D, G e H do projeto de irrigação. Imaginou-se a ocorrência de uma chuva setorial na propriedade que não atingiu as variedades citadas. Esta chuva promoveu a indução floral das outras duas variedades (valência e hamlin), portanto a irrigação deve ser acionada nessas áreas para garantir o "pegamento" dessa floração, mantendo-se as variedades natal e pêra-rio em estresse hídrico.

Como mostra a Figura 29, com a eliminação das parcelas correspondentes às duas variedades, a vazão do projeto diminuiu pela metade e, conseqüentemente a pressão fornecida pela bomba aumentou de 102,0 para 114,6 mca, e as perdas de carga 
diminuíram, promovendo uma sobre-pressão em praticamente toda a malha hidráulica do projeto.

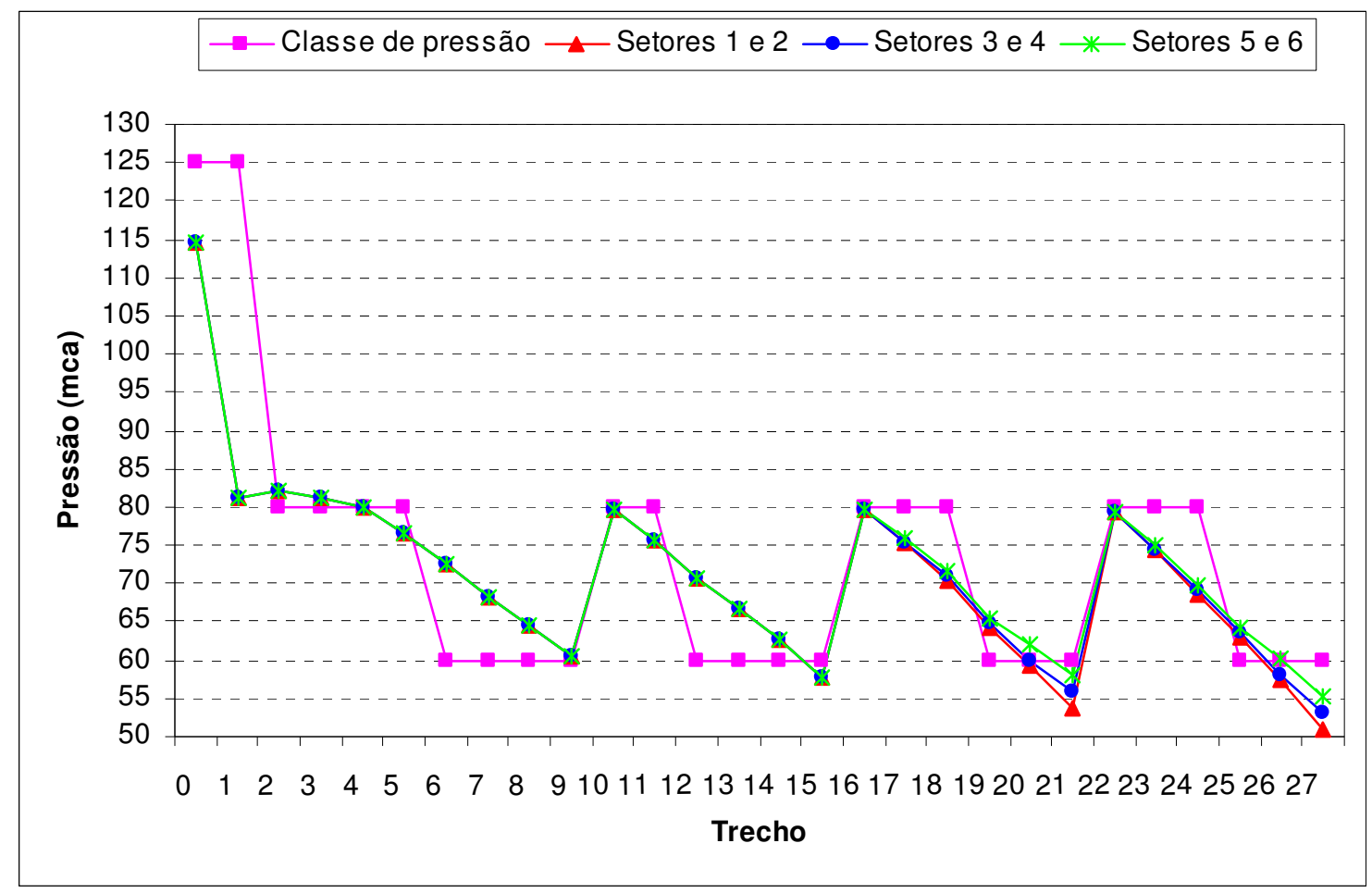

Figura 29 - Gráfico comparativo entre classe de pressão e pressão no final dos trechos da tubulação para simulação 2

\subsubsection{Simulação 3: Desligamento de 1 conjunto moto-bomba visando solucionar o problema de sobre-pressão da malha hidráulica na Simulação 2}

Sendo o sistema de bombeamento composto por dois conjuntos moto-bomba associados em paralelo (soma-se as vazões), simulou-se a eliminação de um dos conjuntos para corrigir o problema de sobre-pressão na malha hidráulica identificado na simulação 2. A Figura 30 mostra a eficiência da alternativa utilizada para adequação do sistema à nova condição de operação, pois todas as pressões situaram-se abaixo da classe de pressão de cada trecho da tubulação. 
Pode-se observar também que, apesar do maior custo de implantação de bombeamentos múltiplos, a associação de bombas em paralelo proporcionou maior flexibilidade no funcionamento do sistema de irrigação estudado; como exemplo, o produtor poderia manter o programa de fertirrigação do pomar nas variedades que estariam sendo irrigadas. Observa-se que para acionamentos elétricos, o bombeamento múltiplo permite o ajuste hidráulico do sistema, para diferentes configurações de setores de operação, apenas com o desligamento de alguns conjuntos moto-bomba, evitando o uso de inversores de freqüência para grandes potências instaladas (elevado custo).

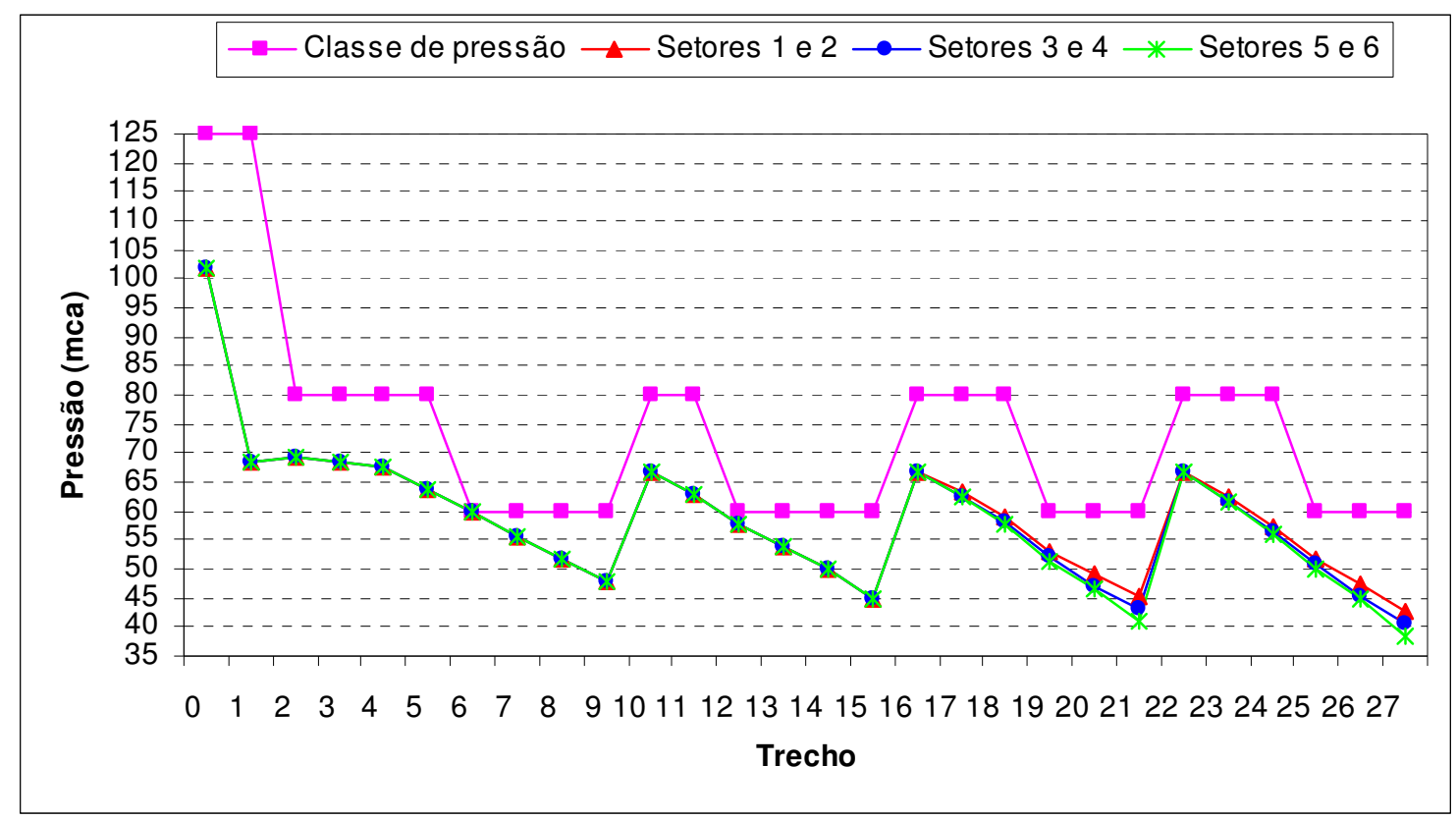

Figura 30 - Gráfico comparativo entre classe de pressão e pressão no final dos trechos da tubulação para simulação 3

laranja valência, correspondente às parcelas $\mathrm{A}$ e B do projeto

\subsubsection{Simulação 4: irrigação das variedades de laranja valência, hamlin, pêra rio e natal isoladamente}

Nesta simulação será considerada a irrigação isoladamente de cada uma das quatro variedades, admitindo que será realizado uma fertirrigação, apenas na área em questão, para correção da fertilidade do solo. Para operar cada setor de 12 parcelas 
isoladamente, dividiu-se em três setores de quatro parcelas cada, sendo o primeiro composto pelos setores 1 e 6 , o segundo pelos setores 2 e 5 e o terceiro pelos setores 3 e 4. Utilizou-se apenas um conjunto moto-bomba nestas simulações. As Figuras 31, 32 e 33 mostram que as pressões nos trechos permaneceram sempre abaixo da classe de pressão da tubulação nos três setores de irrigação determinados para as simulações das variedades de laranja valência, hamlin e pêra rio. $\mathrm{O}$ conjunto moto-bomba manteve as suas características normais de funcionamento, ou seja, rotor dimensionado para o projeto $(377,9 \mathrm{~mm})$ e rotação nominal $(1780 \mathrm{rpm})$ e as pressões na entrada das parcelas estiveram sempre acima do mínimo necessário. Na simulação de operação da laranja natal isoladamente as pressões nos trechos da tubulação permaneceram sempre abaixo da classe de pressão para as condições normais do conjunto moto-bomba, porém, as pressões mínimas necessárias na entrada das parcelas não foram suficientes para manter um bom funcionamento dos emissores. Dessa forma, foi necessário ajustar a rotação do conjunto moto-bomba para $1800 \mathrm{rpm}$, elevando a altura manométrica da bomba de 101,86 mca (1780 rpm) para 104,16 mca, corrigindo a pressão de entrada das parcelas e regularizando o funcionamento dos emissores.

Apesar do aplicativo mostrar a possibilidade de operação das simulações idealizadas neste trabalho, o usuário deve estar atento para não recomendar a operação por períodos extensos, pois trata-se de condições adaptadas e, o uso prolongado, pode trazer sérios danos ao sistema, como por exemplo: na simulação de operação da laranja hamlin, o trecho 2 da tubulação operou com velocidade da água de $0,39 \mathrm{~m} \mathrm{~s}^{-1}$, considerada baixa para os padrões de irrigação, podendo acarretar em acúmulo de areia e de outros materiais sólidos na parte inferior da tubulação, que por ventura sejam captados e não filtrados, além de favorecer o desenvolvimento de microorganismos (algas e bacterérias) e acúmulo de materiais nas paredes da tubulação como bicarbonatos de cálcio, principalmente em algumas regiões do nordeste. $\mathrm{O}$ usuário deve sempre checar se a potência do motor está adequada ao funcionamento do sistema. 


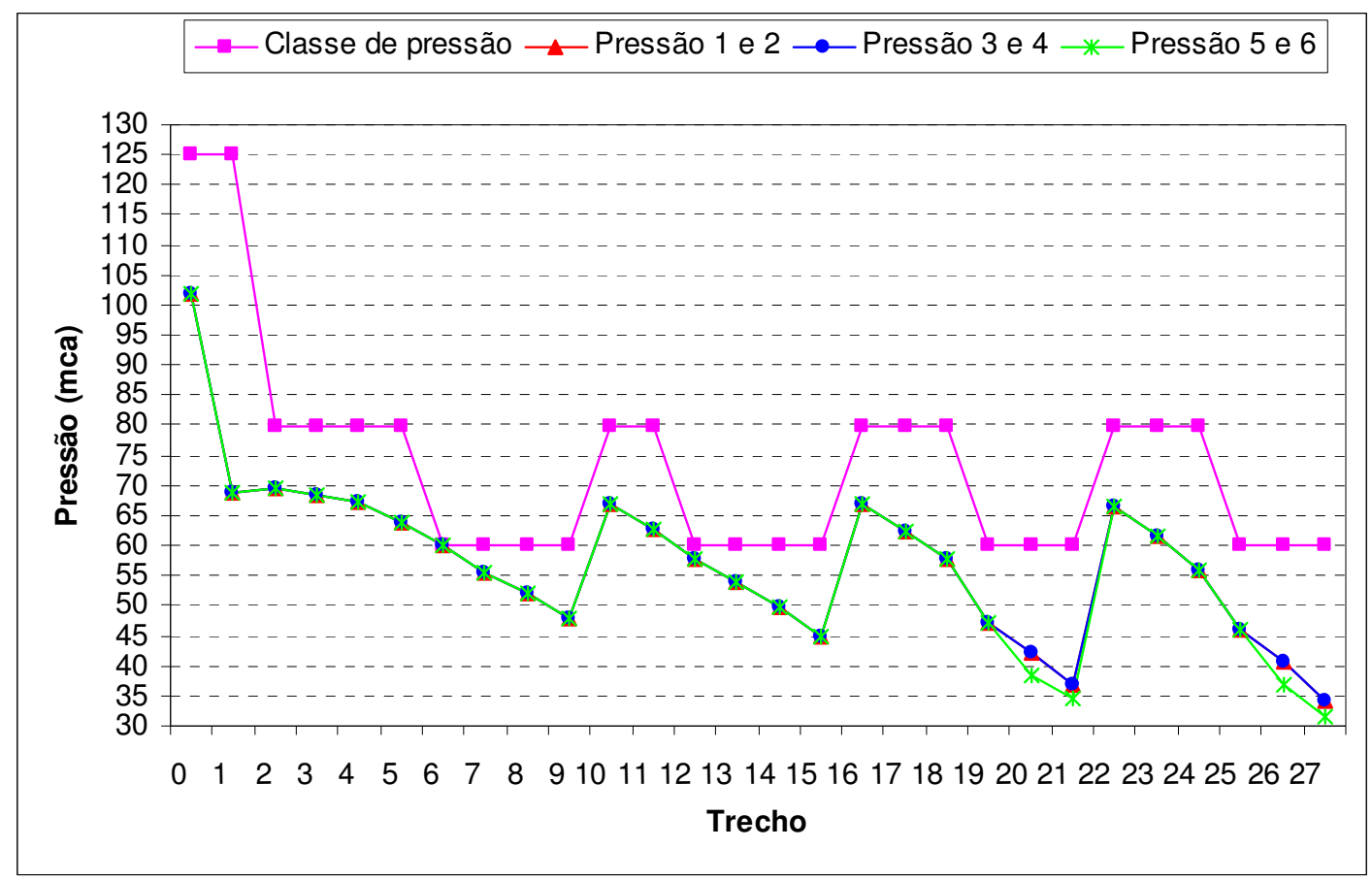

Figura 31 - Gráfico comparativo entre classe de pressão e pressão no final dos trechos da tubulação para simulação 4 e variedade de laranja valência

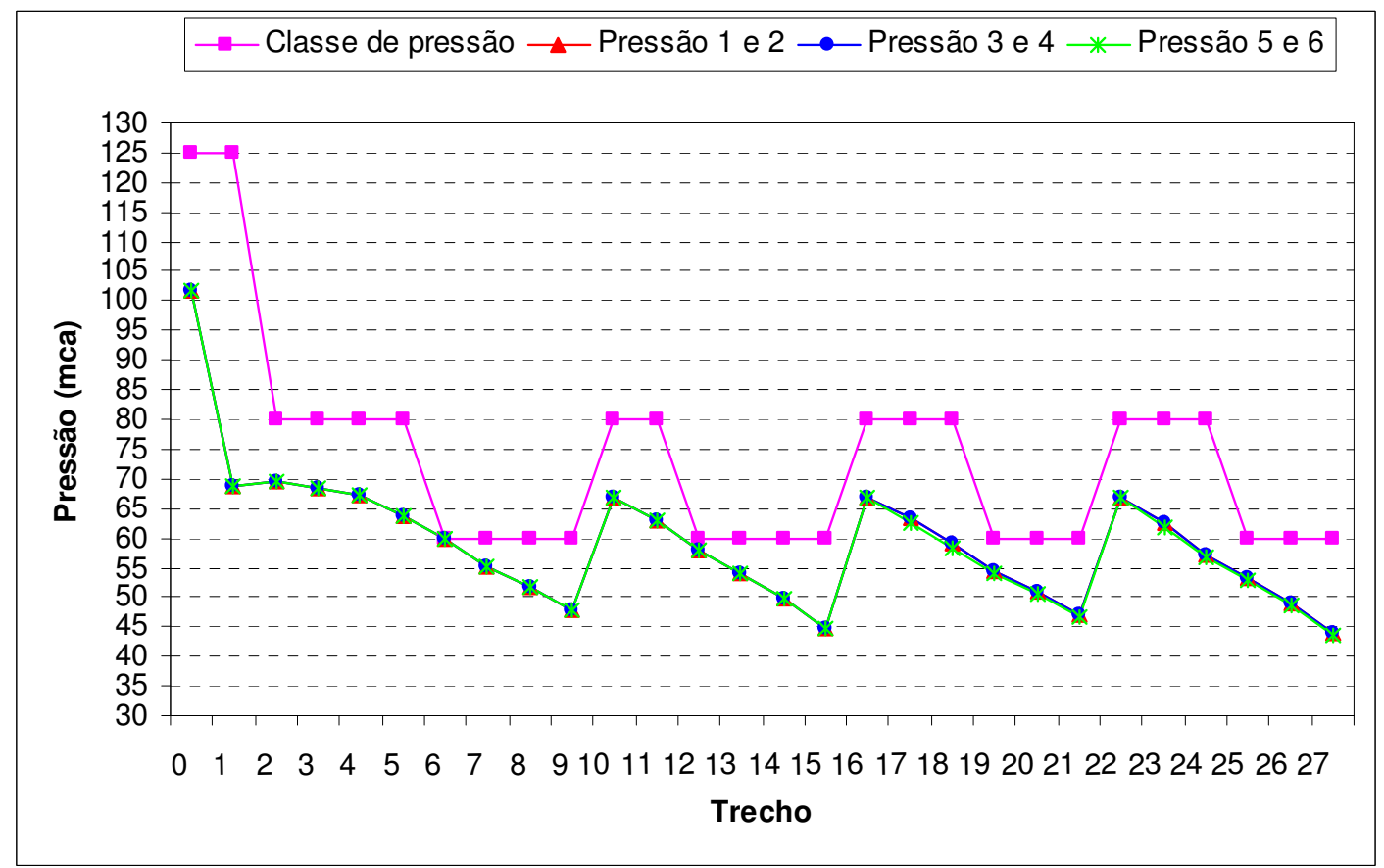

Figura 32 - Gráfico comparativo entre classe de pressão e pressão no final dos trechos da tubulação para simulação 4 e variedade de laranja hamlin 


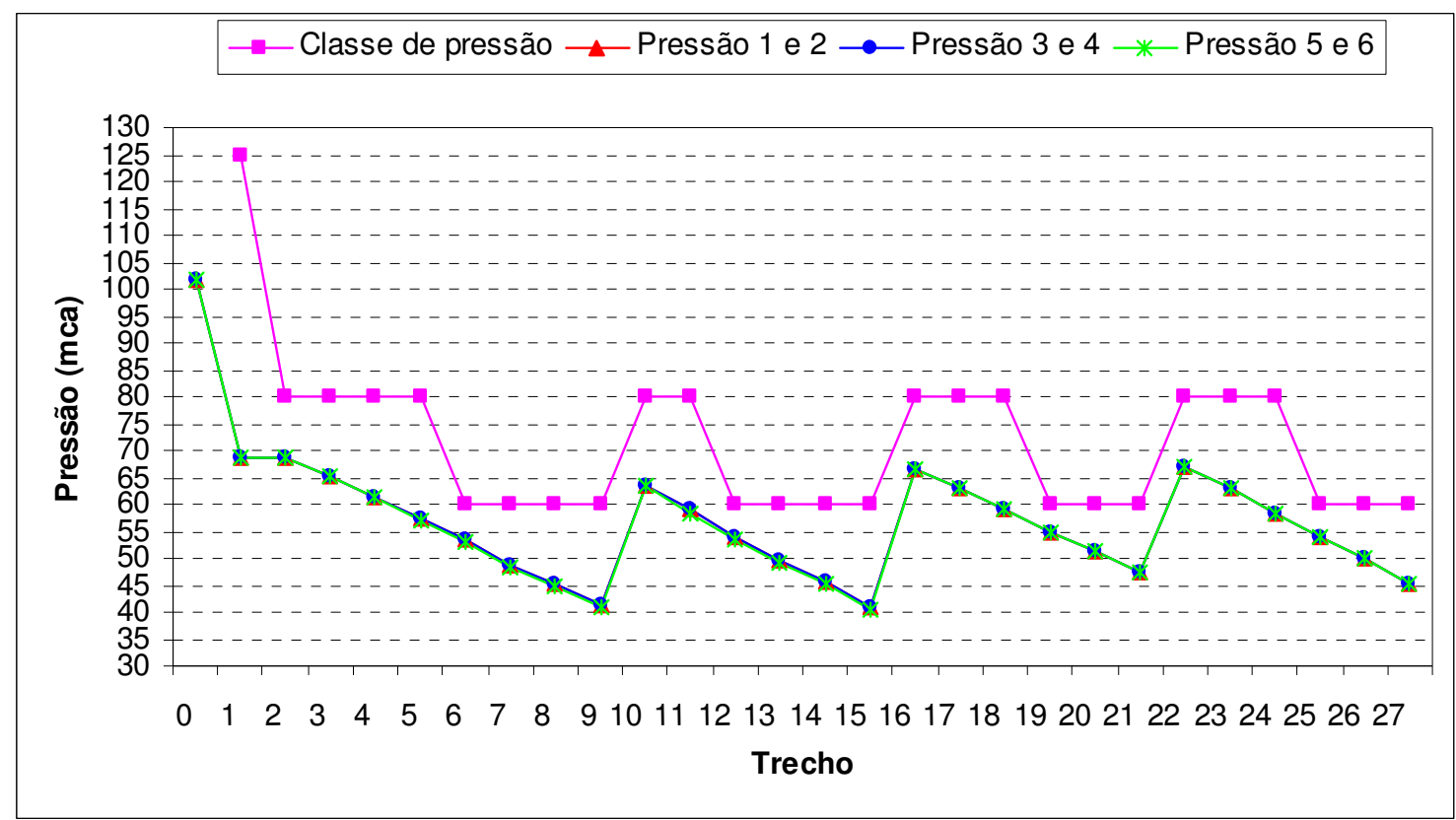

Figura 33 - Gráfico comparativo entre classe de pressão e pressão no final dos trechos da tubulação para simulação 4 e variedade de laranja pêra rio

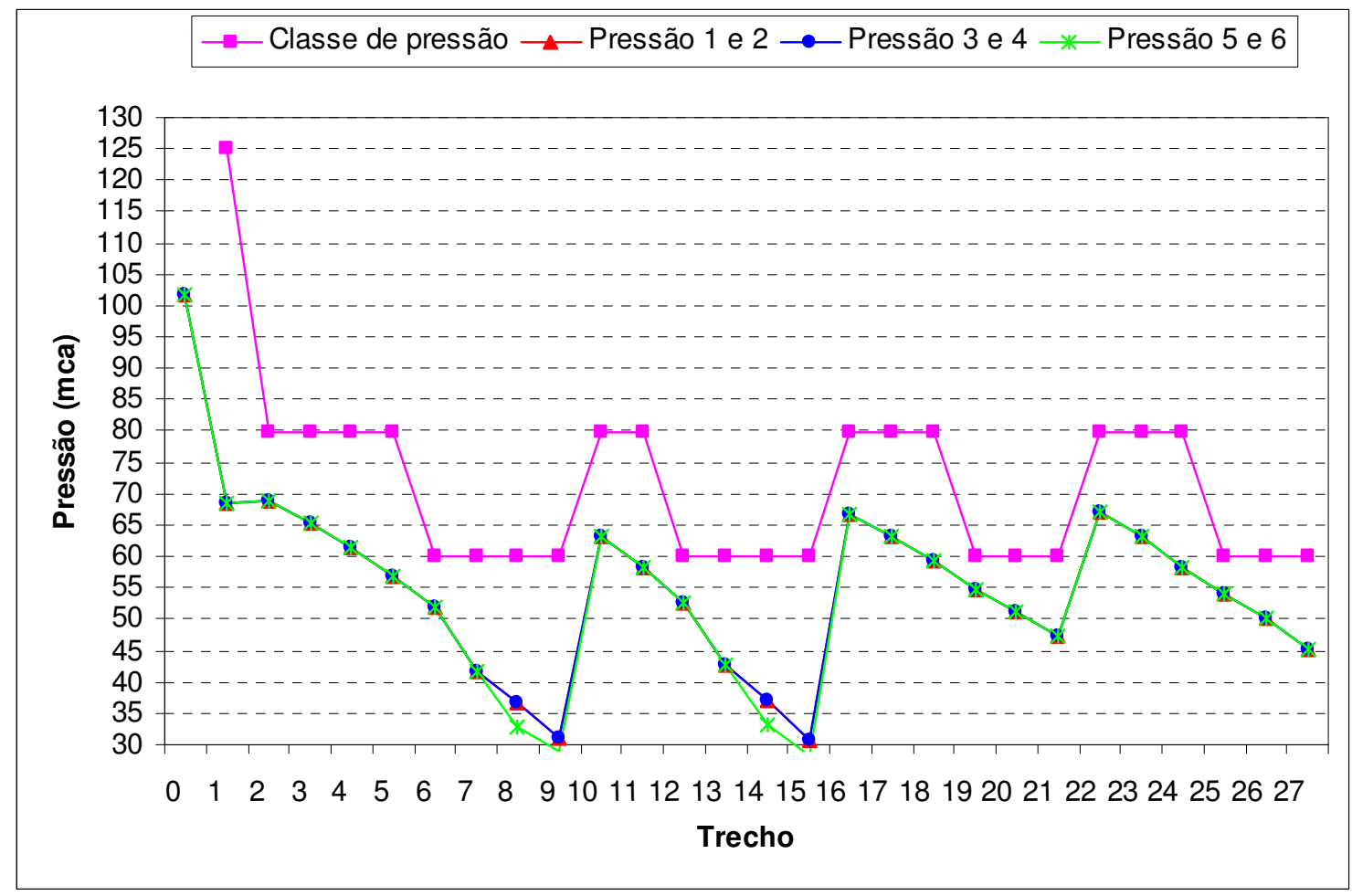

Figura 34 - Gráfico comparativo entre classe de pressão e pressão no final dos trechos da tubulação para simulação 4 e variedade de laranja natal 


\subsection{Considerações finais}

Com base nas experiências vivenciadas segue algumas sugestões para continuidade deste trabalho:

a) introdução das equações das válvulas de controle e proteção utilizadas nos sistemas de irrigação: válvula de alívio de pressão; válvula reguladora de pressão; válvula sustentadora de pressão. A válvula antecipadora de golpe de Aríete envolve transientes hidráulicos e fica fora do objetivo deste trabalho;

b) incluir no aplicativo o dimensionamento de linhas de derivação telescópica e de linhas laterais, permitindo alterar entre linhas simples e linhas duplas e vincular a vazão do sistema à vazão dos emissores por meio das equações características (vazão x pressão) de cada modelo, conforme a pressão de entrada da válvula;

c) permitir o cálculo da uniformidade de distribuição de água (CUC, UD, Hart);

d) construção de banco de dados com emissores e conectores, informando a equação característica (vazão x pressão) e a perda de carga localizada;

e) permitir simulações de associação de um maior número de bombas e rotações, inclusive modelos diferentes e/ou interface com outros softwares já desenvolvidos, como o Maxi-bombas;

f) emissão de relatório do dimensionamento e das simulações geradas e de relação de materiais. 


\section{CONCLUSÕES}

Com base no trabalho desenvolvido, pode-se chegar às seguintes conclusões:

a) O aplicativo mostrou-se eficiente na realização de cálculos hidráulicos, permitindo ao usuário, dimensionar criteriosamente a tubulação principal e secundária de um sistema de irrigação localizada, assim como, identificar diferentes configurações de bombeamento (diâmetro de rotores, rotação da bomba e associação de bombas - série / paralelo) que possibilitem uma operação mais flexível do conjunto moto-bomba;

b) O dimensionamento hidráulico de um sistema de irrigação localizado, não pode ficar restrito unicamente ao projeto original idealizado pelo projetista. O aplicativo desenvolvido permitiu por meio das simulações de funcionamento, ajustar os parâmetros hidráulicos do projeto de irrigação, que venham a atender às necessidades flexíveis do manejo de irrigação de um pomar comercial de citros, escolhendo a combinação de operação de parcelas, associada às características do conjunto motobomba que sejam mais adequadas ao manejo da irrigação em condições reais de operação no campo;

c) $\mathrm{O}$ principal problema apresentado na operação do sistema de irrigação localizado em condições diferenciadas de operação do projeto original é a sobre elevação da pressão na malha hidráulica do sistema, que poderá reduzir a vida útil da tubulação de PVC no campo, promovendo a ruptura de tubulações no campo. A utilização de válvulas hidráulicas de controle, principalmente na saída do cabeçal de filtragem, que propiciam uma determinada pressão a jusante desse ponto, tem sido a opção técnica mais utilizada em campo; embora seja uma alternativa do ponto de vista 
hidráulico para garantir a integridade da malha hidráulica, do ponto de vista energético não deve ser incentivado pois propicia desperdício de energia elétrica / diesel, sendo que o controle da rotação e / ou o desligamento parcial dos conjuntos moto-bomba são as opções técnicas mais eficientes. 
ANEXOS 
ANEXO 1. Curvas características da bomba Imbil ITAP 100-500/2 a 1780 rpm
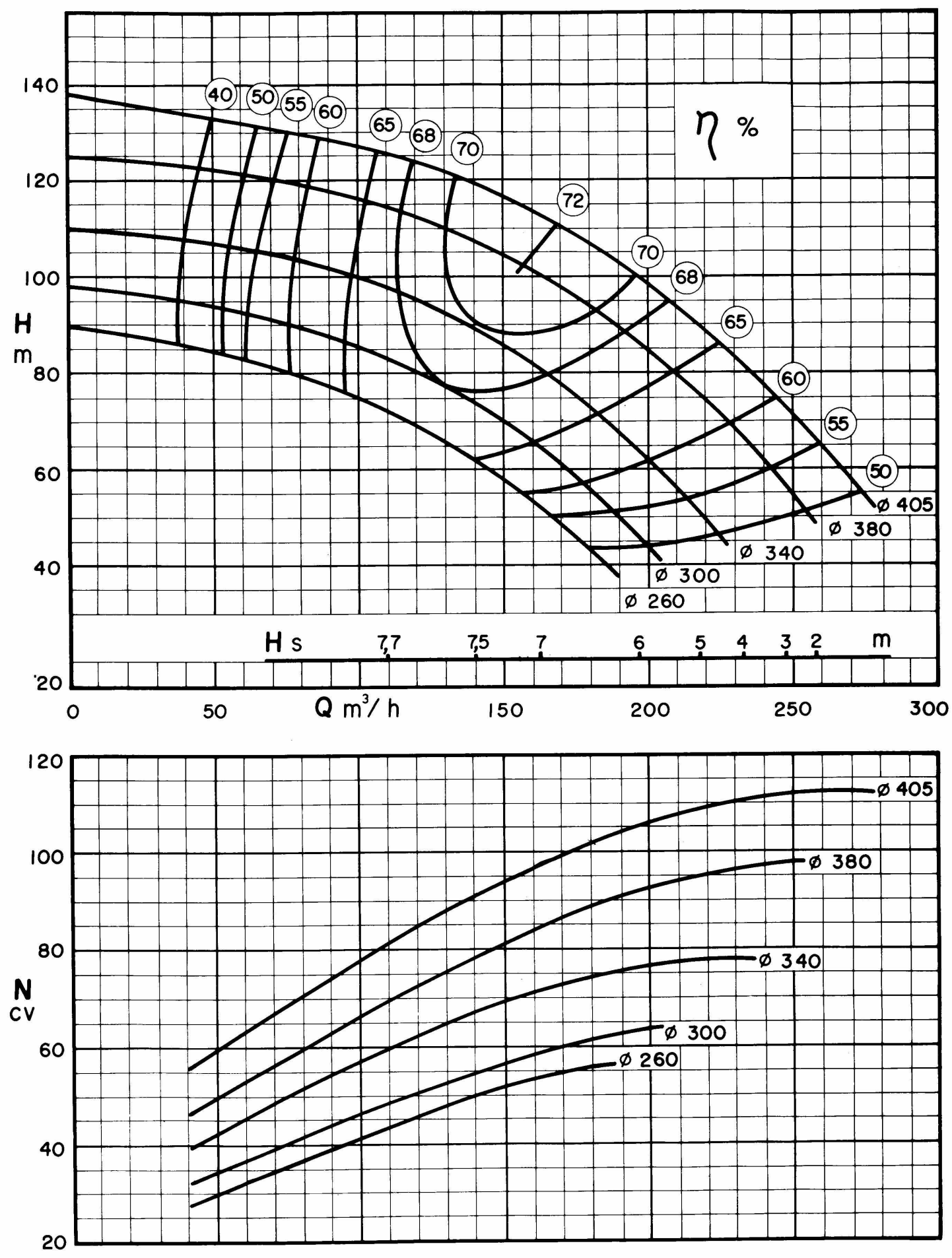
ANEXO 2. Curvas de consumo específico, torque e potência do motor MWM D-229 -6 veicular (similar ao modelo estacionário, até 2500 rpm)

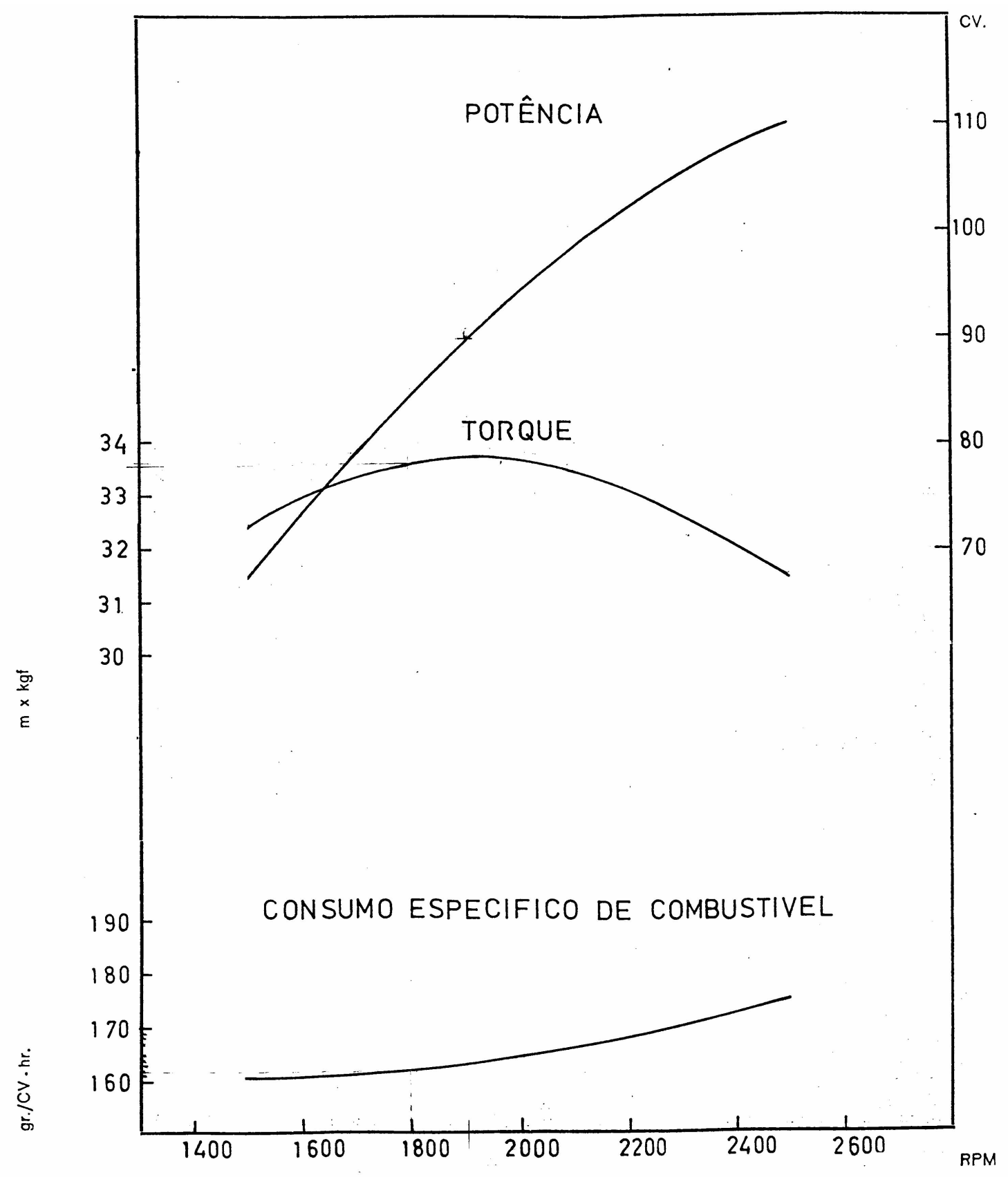




\section{REFERÊNCIAS BIBLIOGRÁFICAS}

ALLEN, R.G.; BROCKWAY, C.E. Concepts for energy-efficient irrigation system design. Journal of Irrigation and Drainage Engineering, v.110, n. 2, p. 99-106, Jun, 1984.

AZEVEDO NETTO, J.M.; FERNANDEZ, M.F.; ARAÚJO, R. de; EIJI ITO, A. Manual de Hidráulica. 8. ed. S. Paulo: Blucher, 1998. 669 p.

BERNARDO, S. Manual de Irrigação. 6. ed. Viçosa: Imprensa Universitária, 1995. $657 \mathrm{p}$.

BONGANHA, A.C. Meio ambiente: o uso da água na irrigação e o licenciamento ambiental. Citricultura Atual, v. 5, n. 25, p.14-15, dez 2001.

COMPANHIA DE ENERGIA ELÉTRICA DE MINAS GERAIS. Estudo de otimização energética. Belo Horizonte, 1993. 22 p.

CHRISTOFIDIS, D. Situação das áreas irrigadas: métodos e equipamentos de irrigação - Brasil. http://www.mma.gov.br/port/srh/acervo/publica/doc/srhde (24 mar. 2002).

CHRISTOFIDIS, D. Irrigação, a fronteira hídrica e a produção de alimentos. Irrigação e Tecnologia Moderna - ITEM, n.54, p.46-55, 2002. 
CRUCIANI, D.E. Hidráulica: equações, tabelas e gráficos. Piracicaba: Centro Acadêmico “Luiz de Queiroz”, 1996. 128p.

DAKER, A. Hidráulica aplicada à agricultura: A água na agricultura. 6. ed. Rio de Janeiro: Freitas Bastos, 1983. 316p.

DE MATOS, J. de A. Aplicação da programação não linear no dimensionamento de projetos de irrigação localizada. Botucatu, 2000. 89p. Tese (Doutorado) Universidade Estadual Paulista "Júlio de Mesquita Filho".

DENÍCULI, W. Bombas Hidráulicas. Viçosa: UFV, 2001. 162p.

FARIA, L.F; COELHO, R.D.; FLECHA, P.A.N.; ROBLES, W.G.R.; NAVARRO VÁSQUEZ, M.A. Entupimento de gotejadores e seus efeitos na pressão da rede hidráulica de um sistema de microirrigação. Revista Brasileira de Engenharia Agrícola e Ambiental, v.6, n.2, p.195-198, 2002.

GOMES, H. P. Redes: a software for optimum design of irrigation pipeline systems. In: INTERNATIONAL CONFERENCE ON COMPUTERS IN AGRICULTURE, 6., Cancun, 1996. Anais. Cancun: 1996. p. 46-52.

HOLZAPFEL, E.A.; MARINÕ, M.A.; VALENZUELA, A. Drip Irrigation Nonlinear Optimization Model. Journal of Irrigation and Drainage Engineering, v.116, n.4, p.479-496, Jul, 1990.

LIMA, J.E.F.W; FERREIRA, R.S.A.; CHRISTOFIDIS, D. $O$ uso da irrigação no Brasil. http://www.ana.gov.br/usuários/agropecuária/main.htm (24 mar. 2002). 
MAIA, L.A.F. Desenvolvimento de um software para auxiliar no dimensionamento e manejo da irrigação localizada. Piracicaba, 1994. 158p. Dissertação (Mestrado) Escola Superior de Agricultura “Luiz de Queiroz”, Universidade de São Paulo.

MIALHE, L. G. Máquinas Agrícolas: ensaios \& certificação. Piracicaba: Fundação de estudos agrários Luiz de Queiroz, 1996. 722p.

PORTO, R.M. Hidráulica Básica. 2. ed. São Carlos: EESC-USP, 2001. 519 p.

SAAD, J.C.C. Otimização de sistemas de irrigação localizada utilizando programação não-linear. Piracicaba, 1993. 115p. Tese (Doutorado) - Escola Superior de Agricultura "Luiz de Queiroz”, Universidade de São Paulo.

SAAD, J.C.C.; MARINÕ, M.A. Optimum design of microirrigation systems in sloping lands. Journal of Irrigation and Drainage Engineering, v.128, n. 2, p. 116-124, Mar 2002.

SAAD, J.C.C.; TOMAZELA, C.; PERES, G.J.; PERES, F.C.; FRIZZONE, J.A. Otimização da rede hidráulica de um sistema de irrigação por gotejamento utilizando programação linear. Pesquisa Agropecuária Brasileira, v.29, n. 5, p.797-805, 1994.

SCHMITZ, G.H.; SCHUTZE, N.; PETERSOHN, U. New strategy for optimizing water application under trickle irrigation. Journal of Irrigation and Drainage Engineering, v. 128, n. 5, Oct 2002.

SILVA, R. C. A. Otimização de redes ramificadas através do método de programação não linear. Campina Grande, 1997. 158p. Dissertação (Mestrado) - Universidade Federal da Paraíba. 
SOUSA, E. F. Modelo computacional aplicado ao manejo e planejamento da irrigação. Viçosa, 1993. 65 p. Dissertação (Mestrado) - Universidade Federal de Viçosa.

SOUZA, S.A.V.; FRIZZONE, J.A.; PERES, F.C. Otimização da irrigação para diferentes défict nas lâminas de água aplicadas às culturas. Engenharia Rural. v. 9, n. 1, p.1-9, 1998

SOUZA, E.F.; BERNARDO,S.; BERBERT, P.A. DROP 2000: Dimensionamento racional de irrigação localizada orientado por computador; manual do usuário. s.e.: s.ed., 2000. 81p.

THAME, A.C.M. Água: a iminência da escassez. s.n.t. 12 p.

VERMEIREN, L. Irrigação localizada. Trad. de H.R. Gheyi, F.A.V.Damasceno, L.G.A. Silva Jr. e J.F. de Medeiros. Campina Grande: UFPB, 1997. 184p. 